\title{
Review of the genus Ceraturgus Wiedemann (Diptera: Asilidae) in North America north of Mexico
}

\author{
JEFFREY K. BARNES \\ University of Arkansas, Department of Entomology, The Arthropod Museum, Fayetteville, Arkansas 72701. \\ E-mail: jbarnes@uark.edu
}

\section{Table of contents}

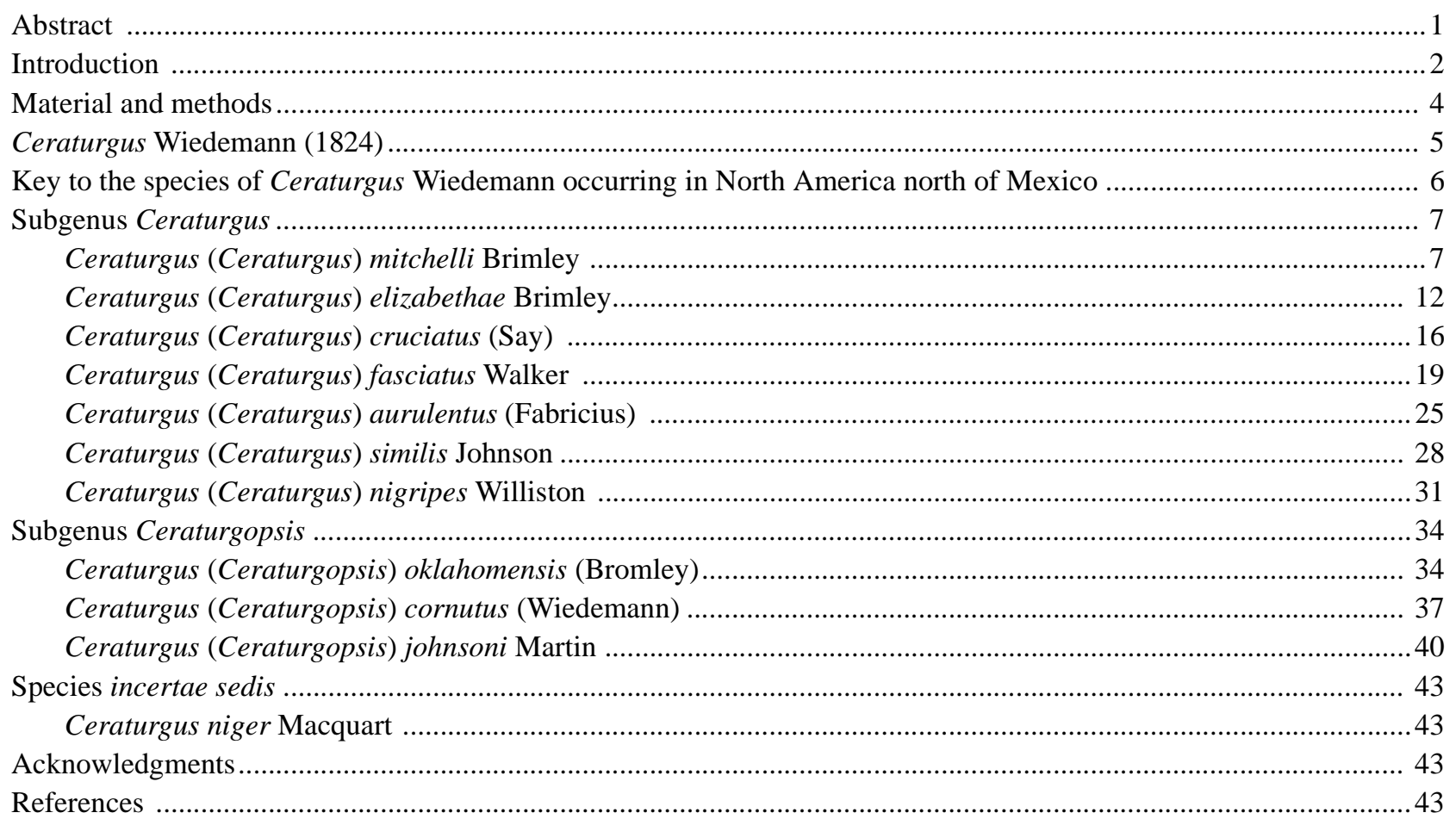

\begin{abstract}
The species of Ceraturgus occurring in the eastern United States and Canada are reviewed. A key to species, descriptions, illustrations of wings and some genitalic features, and distribution maps are presented. Ceraturgus fasciatus is resurrected from synonymy with Ceraturgus cruciatus, and Ceraturgus mabelae is reduced to synonymy with Ceraturgus nigripes (new synonymy). Ceraturgopsis is resurrected, assigned subgeneric rank, and Ceraturgus cornutus is fixed as type species. This work is dedicated to the memory of one of America's foremost asilidologists, Joseph Wilcox.
\end{abstract}

Key words: Ceraturgopsis, robber flies, Nearctic, Joseph Wilcox 


\section{Introduction}

The robber fly genus Ceraturgus, now placed in subfamily Stenopogoninae (Geller-Grimm 2003), includes some of the rarest robber fly species in North America. They are distinctive wasp-mimicking flies with long, 5-segmented antennae. Wiedemann (1824) described the genus Ceraturgus in 1824 to receive the single distinctive species Dasypogon aurulentus Fabricius, known at that time from a single specimen, "Habitat in New-York Americes Dom. de Sehestedt" (Fabricius 1805). A year earlier, Say (1823) published a description of Dasypogon cruciatus from "Arkansa". That species would later be placed in Ceraturgus. Four years after erecting Ceraturgus, Wiedemann (1828) described Dasypogon cornutus from a specimen of unknown provenance. This species is much larger than $C$. aurulentus and has a different antennal structure, bearing a short apical flagellomere. Nonetheless, Wiedemann (1828) speculated that it might be a species of Ceraturgus. Macquart (1838) described Ceraturgus niger "de l'Amérique boréale," but no subsequent worker has been able to place this species. Walker (1849) described $C$. fasciatus from a male collected in New York, and Walker (1854) listed Macquart's C. niger from Mexico. Loew (1873) commented that $C$. fasciatus should be synonymized with $C$. cruciatus. In his North American Diptera catalog, Osten Sacken (1878) transferred Say's D. cruciatus to Ceraturgus and, without comment, synonymized both $C$. fasciatus and D. cornutus with it. Williston (1886) described $C$. nigripes from a relatively small male collected in Georgia, and he commented that the "pedes flavi" of $C$. aurulentus prevents its confusion with this species, which has black tarsi.

Johnson (1903) described the new genus Ceraturgopsis with D. cornutus as the type species, although the specimens before him were actually at that time an undescribed new species. Johnson (1910) recorded a single specimen of $C$. nigripes from Mt. Equinox, Bennington County, Vermont, but he later (Johnson 1912) described Ceraturgus similis from a male holotype collected in Massachusetts and identified the Mt. Equinox specimen as his new species. He concluded that the species is readily distinguished from $C$. nigripes by its yellow tibiae and tarsi and brownish wings. Brimley (1924) described three new North American species, $C$. elizabethae from a mating pair, C. mabelae from a single female, and C. mitchelli from a single male, all collected in North Carolina. Bromley (1934) described a new Ceraturgopsis, C. oklahomensis, from a male holotype collected in Caddo County, Oklahoma. Martin (1965) described Ceraturgus johnsoni from the Florida specimens misidentified as Ceraturgus cornutus that Johnson had before him when he erected Ceraturgopsis. In this work, Ceraturgopsis is assigned subgeneric rank.

Few species from outside the United States and Canada have been assigned to Ceraturgus. Kertész (1909) listed 10 species from various parts of the world. Of them, the Neotropical species C. dimidiatus (Macquart), C. geniculatus Bigot, and C. rufipennis Macquart are now placed in Taracticus (Martin and Papavero 1970), and the Palearctic species C. brevis (Schiner) and C. nubilus (Wiedemann) have been transferred to Heteropogon, with C. brevis a junior synonym of $C$. nubilus (Hull 1962). Ceraturgus kawamurae Matsumura (1916) was described from Japan. Wilcox (in litt.) studied a specimen and considered it to be a true Ceraturgus. Ceraturgus hedini Engel (1934) was described from China, and its distinctively Ceraturgus-type antennae were illustrated. A species only provisionally assigned to Ceraturgus, Ceraturgus (?) andocides Walker (1849), was described from a male with 5-segmented antennae. Its provenance is unknown. Loew (1873) described $C$. dispar, but it is now known as Myelaphus dispar (Loew). Ceraturgopsis praecursor James (1939) was described from a fossil found in Colorado Florissant Miocene shale.

Loew (1873) made the following comments on the genus Ceraturgus, here translated from the German:

To my knowledge, nine Ceraturgus species have been described; seven from the North American continent, of which Ceratrugus fasciatus male of Walker must be synonymized with Dasypogon cruciatus female of Say. The native country of the species described by Wiedemann as Dasypogon cornutus is unknown, but it can probably be surmised to be North America, since from Wiedemann's data the structure of the antennae does not seem to differ from that of the other North American species. Mr. Walker considers Ceraturgus andocides, of unknown native country, only doubtfully belonging to Ceraturgus, unfortunately without indi- 
cation concerning the reasons for which he is doubtful. Therefore, Ceraturgus apparently occurs only in the North American continent, so this discovery of an Old World form is particularly interesting. It differs from the North American species by a somewhat different structure of the same antennal plan and by the distinctive fourth posterior marginal cell of the wings, however it otherwise agrees with them in enough substantial characteristics that no reason is present to now separate it from them generically.

Little is known about the biology of Ceraturgus species. Bromley (1928) claimed that C. cruciatus mimics a vespid queen, either Vespa communis Saussure (= Vespula vulgaris (Linnaeus)) or V. diabolica Saussure (= Dolichovespula aranaria (Fabricius)). He later (Bromley 1950b) claimed that Ceraturgus cruciatus in Ohio (=C. fasciatus) is a fair mimic of the queen yellow jacket, Vespula maculifrons (Buysson) or $D$. arenaria, that $C$. dimidiatus $(?=C$. mitchelli) is a fair mimic of the queen hornet $D$. maculata (Linnaeus), and that $C$. aurrulentus is a fair mimic of the worker yellow jacket, $V$. maculifrons or $D$. arenaria.

Bromley (1928) recorded 14 known prey of a Ceraturgus species: nine beetles, four winged ants, and one spittle bug. His records apparently came from the Massachusetts Agricultural Experiment Station, and therefore the robber fly species probably was $C$. fasciatus, rather than the stated $C$. cruciatus. Most of the prey records that are presented in this paper are beetles, especially scarabs, and some Hymenoptera, especially ants.

Bromley (1946) listed C. fasciatus (as C. cruciatus) as a woodland species of Connecticut's oak and mixed mesophytic region, and recorded the rose chafer, Macrodactylus subspinosus (Fabricius) as prey of two different individuals. He also found a teneral female $C$. aurulentus resting on a freshly cut black birch stump in a woodland clearing in Connecticut. In Japan, C. kawamurae Matsumura has been observed on low bushes, herbaceous plants, and grasses along rivers and creeks. Ohishi (1997) found individuals congregating on flowering Viburnum shrubs in mid June. They were preying on small insects attracted to the flowers. Harusawa (1997) found several males and females in early June resting on short trees and grasses near a creek in a V-shaped valley. Ceraturgus elizabethae Brimley is here recorded as an inhabitant of upland, open- and closed-canopy woodland sites well removed from running and standing water. The presence of acanthophorite spines in the ovipositor suggests that female Ceraturgus lay eggs in soil. A specimen of C. fasciatus from Cummington, Hampshire County, Massachusetts, deposited in the National Museum of Natural History is labeled, "ovipositing in soft earth."

Dedication. This paper is dedicated to the memory of Joseph Wilcox (1901-1982). It is based in part upon an unfinished and unpublished manuscript written by him, dated 1975. A copy of the manuscript was given to me by Eric Fisher in 2004, along with encouragement to finish the work. A thorough examination of the manuscript has proven that, although Wilcox did not study the type specimens, he had a thorough understanding of species limits within the genus Ceraturgus. In the lists of material examined that follow, the abbreviation JW refers to specimens examined by Joseph Wilcox.

Wilcox received his Master of Science degree in 1928 from Oregon Agricultural College. His thesis was entitled The species of root-weevils attacking strawberry with especial reference to their life history, habits and control in Oregon. He spent most of his career studying biology and control of fruit and vegetable insects in California for the Bureau of Entomology, United States Department of Agriculture. Wilcox began publishing brief accounts on robber fly taxonomy as early as 1935. For a decade after retiring in 1962, he vigorously pursued these studies, and to this day he is considered the leading describer of Nearctic robber flies. He published about 40 papers in this field, and he proposed nearly 160 names for Nearctic taxa, with more than $96 \%$ validity. Wilcox and his wife Itol traveled extensively in the American West, collecting robber flies and other insects. Their collection of some 25,000 specimens is now at the California Academy of Sciences (Stone 1980, Barnes 1984). 


\section{Material and methods}

Terminology largely follows that found in the Manual of Nearctic Diptera (McAlpine 1981). Body length refers to the distance from the front of the head to the tip of the abdomen and excludes the length of the antennae. Antennomere:scape ratios were calculated by dividing the length of each antennomere by the length of the first antennomere (scape). The numbers are listed in order from antennomere 1 to antennomere 5 . Therefore, the ratios 1.0:0.9:2.7:0.6:3.6 indicate that the pedicel is a little shorter than the scape, and the fifth antennomere (third flagellomere) is a little longer than the third antennomere (first flagellomere).

The following work is based on examination of some 700 specimens, including types, held by more than 40 institutions. Repository acronyms are based on the list of abbreviations for insect and spider collection of the world (Evenhuis 2008): AMNH, The American Museum of Natural History, New York City; ANSP, The Academy of Natural Sciences, Philadelphia; BMNH, The Museum of Natural History, London; BYU, Monte L. Bean Life Science Museum, Brigham Young University, Provo, Utah; CAS, California Academy of Sciences, Department of Entomology, San Francisco; CLEV, Cleveland Museum of Natural History, Ohio; CMNH, Carnegie Museum of Natural History, Pittsburgh; CNC, Canadian National Collection of Insects, Arachnids and Nematodes, Ottawa; CSCA, California State Collection of Arthropods, California Department of Food and Agriculture, Sacramento; CSUC, C. P. Gillette Museum of Arthropod Diversity, Department of Bioagricultural Sciences and Pest Management, Colorado State University, Ft. Collins; CUAC, Clemson University Arthropod Museum, Clemson, South Carolina; CUIC, Cornell University Insect Collections, Department of Entomology, Cornell University, Ithaca, New York; EMEC, Essig Museum of Entomology, University of California, Berkeley; EMUS, Entomological Museum, Department of Biology, Utah State University, Logan; ESUW, Insect Museum, Department of Renewable Resources, University of Wyoming, Laramie; FMNH, Field Museum of Natural History, Chicago; FSCA, Florida State Collection of Arthropods, Florida Department of Agriculture, Division of Plant Industry, Gainesville; INHS, Insect Collection, Illinois Natural History Survey, Champaign; IRCW, Insect Research Collection, Department of Entomology, University of Wisconsin, Madison; KSUC, Department of Entomology, Kansas State University, Manhattan; LSAM, Louisiana State Arthropod Museum, Department of Entomology, Louisiana State University, Baton Rouge; MCZ, Museum of Comparative Zoology, Harvard University, Cambridge, Massachusetts; MEM, Mississippi Entomological Museum, Mississippi State University, Mississippi State; MWNH, Museum Wiesbaden; NCSU, North Carolina State University Insect Collection, Raleigh; NMW, Naturhistorisches Museum Wien; NYSM, New York State Museum Insect Collection, Albany; OSEC, K. C. Emerson Museum, Oklahoma State University, Stillwater; OSU, Charles A. Triplehorn Insect Collection, Ohio State University, Columbus; PSUC, Frost Entomological Museum, Department of Entomology, Pennsylvania State University, University Park; SEMC, Snow Entomological Collections, University of Kansas Natural History Museum, Lawrence; TAMU, Insect Collection, Department of Entomology, Texas A\&M University, College Station; UAAM, Arthropod Museum, Department of Entomology, University of Arkansas at Fayetteville; UDCC, Insect Reference Collection, University of Delaware, Newark; UGCA, Entomology Collections, Georgia Museum of Natural History, University of Georgia, Athens; UMMZ, Insect Division, University of Michigan Museum of Zoology, Ann Arbor; UMRM, Wilbur R. Enns Entomology Museum, Department of Entomology, University of Missouri, Columbia; UMSP, University of Minnesota Insect Collection, St. Paul; USNM, National Museum of Natural History, Smithsonian Institution, Washington, D.C.; WFBM, William F. Barr Entomological Museum, Entomology Division, University of Idaho, Moscow; WSU, The James Entomological Collection, Department of Entomology, Washington State University, Pullman; WTAM, Department of Life, Earth, \& Environmental Sciences, West Texas A\&M University, Canyon, Texas; ZMUC, Universitets Zoologisk Museum, Copenhagen. 


\section{Ceraturgus Wiedemann (1824)}

Ceraturgus Wiedemann, 1824: 12. Type species: Dasypogon aurulentus Fabricius, by monotypy.

Body length, excluding antennae, less than $28 \mathrm{~mm}$. Head width 1.5-1.6 times eye height; face in profile produced beyond eye margin, lacking pronounced tentorial pits; mystax occupying lower half or more of face; sides of frons more or less parallel sided, not strongly converging or diverging dorsally; compound eye with anterior ommatidia greatly enlarged; ocellar tubercle low, bearing several stout setae and shorter hair-like setae; occipital pile dense. Proboscis laterally compressed, apically blunt; palpus 2-segmented. Antennae exceptionally long, much longer than head, with 5 antennomeres, including 3 elongate flagellomeres; scape and pedicel subequal; first flagellomere less than twice length of scape and pedicel combined; second flagellomere short, about half length of scape; antennal bases on raised area. Thorax with scutum typically vittate, bearing sparse or dense pile of short or long, erect or reclinate, hair-like setae shorter or longer than scape; anepisternum and katepisternum bearing many long or short setae; katatergite bearing fan of long setae; anatergite tomentose, lacking long setae; scutellem low convex, bearing band of long marginal bristles; postmetacoxal area membranous. Femora stout but not swollen, usually with apical circlet of stout setae; fore and mid femora with $0-5$ stout anterior setae; hind femur usually with anterior row of 2-8 stout setae. Fore tibia with all apical bristles straight, usually with anterodorsal and posterodorsal rows of short, stout setae and posteroventral row of long, stout setae; mid tibia with apical ventral bristles directed distally, not toward body, usually with anterodorsal, anteroventral, posterodorsal, and posteroventral rows of stout setae; hind tibia with anterior, dorsal, and ventral rows of stout setae; pulvilli present. Wing hyaline to moderately infuscated; vein $\mathrm{C}$ continuing around posterior wing margin to wing base; $\mathrm{R}_{2+3}$ ending in $\mathrm{C}$, its apex not directed sharply forward before ending in $C ; R_{4}$ not unusually arched and sinuate; apical portion of $\mathrm{M}_{3}$ at an angle to crossvein $\mathrm{m}$ $\mathrm{m} ; \mathrm{CuA}_{2}$ and $\mathrm{A}_{1}$ ending separately; cell $\mathrm{m}_{3}$ open at wing margin; cell cup closed or narrowly open at wing margin. Prosternum not fused to proepisternum. Abdomen usually black with conspicuous white to yellow pollinose posterior fascia; segment 2 not unusually elongate; gonocoxite often bilobed, bearing tuft of long, stout setae; tergite 10 with strong bristles in female.

Discussion. Wiedemann (1824) described the genus Ceraturgus to receive the single distinctive species Dasypogon aurulentus Fabricius, known at that time from a single specimen, "Habitat in New-York Americes Dom. de Sehestedt" (Fabricius 1805). His brief description distinguished the genus primarily on antennal characters: antennae porrect, long, 5-segmented: segments 1-3 subclavate, segment 4 cup-shaped, 5 with obtuse apex; body naked.

The Asilidae have not yet been subjected to thorough phylogenetic analysis, although work is presently underway. Higher classification within the family remains unstable. Artigas and Papavero (1991a) included the genera Ceraturgus and Myelaphus in their new tribe Ceraturgini of the subfamily Stenopogoninae. Stenopogoninae are recognized by the following combination of characters: prothoracic tibia lacking a differentiated apical spur (stouter than others, or twisted and sigmoid), vein $\mathrm{R}_{2+3}$ ending in vein $\mathrm{C}$, prosternum not fused to proepisternum, ovipositor with acanthophorite spines (Wood 1981, Artigas and Papavero 1988). These features are presumed to be plesiomorphic, so the subfamily probably is not monophyletic.

Female Ceraturgus, like many other orthorrhaphous Brachycera (e.g. Mydidae, Apioceridae, Therevidae, Scenopinidae, and Dolichopodidae, and some other Asilidae), have tergite 10 divided into a pair of spinebearing hemitergites called ancathophorites, used for digging during oviposition (McAlpine 1981). According to Papavero (1973), primitive asilid female terminalia have spined acanthophorites. Reduction of spines and fusion and elongation of the two acanthophorites led to the formation of several types of ovipositors found in other groups of robber flies. He found spined acanthophorites in only some genera of Stenopogoninae, Dasypogoninae, Apocleinae, and Asilinae. He found them lacking in Laphystiinae, Laphriinae, Ommatiinae, and Trigonomiminae. 
Ceraturgini have the head wider than high, antennae with 3 flagellomeres (total of 5 antennomeres), third flagellomere pubescent and as wide or wider than first flagellomere (Artigas and Papavero 1991a). Ceraturgus lacks the deep clefts at the apices of the first and second flagellomeres that are found in Myelaphus.

The name Ceraturgus is derived from the Greek word Keratourgos, meaning horn-maker.

\section{Key to the species of Ceraturgus Wiedemann occurring in North America north of Mexico}

1 Third flagellomere long, as long as or longer than scape and pedicel combined, densely covered with long pubescence ..subgenus Ceraturgus Wiedemann .....

- Third flagellomere short, about as long as scape, densely covered with short pubescence .. subgenus Cer-

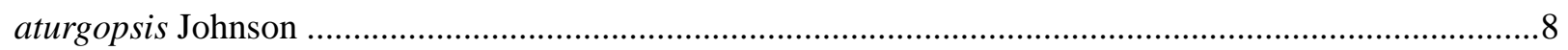

2 Larger species, rarely under $16 \mathrm{~mm}$ long; wings distinctly infuscated, especially anteriorly, near base; male prothoracic pulvilli brown, female pulvilli yellow .....

- Smaller species, rarely over $14 \mathrm{~mm}$ long, wings mostly or completely hyaline, or only lightly uniformly infuscated; male and female pulvilli all yellow.

3 Face white or pale yellow pollinose; mystax white; third flagellomere much shorter than first flagellomere; scutellar margin with many moderately strong bristles as long as or longer than scutellum; hind tibia and tarsus black, often lighter at articulations; wings lightly infuscated at base; abdominal tergites 2-3 with white posterior pollinose bands produced forward at lateral margins; Pennsylvania and Florida west to Nebraska and Texas..... Ceraturgus (Ceraturgus) mitchelli Brimley

- Face golden pollinose; mystax yellowish brown to brown; third flagellomere about as long as or longer than first flagellomere; scutellar margin with only very weak hair-like setae shorter than or equal to length of scutellum; all tibiae and tarsi yellow; wings infuscated throughout, especially at base; abdominal tergites $2-3$ with yellow posterior pollinose bands not produced forward at lateral margins

4 Postalar callus mostly shining brown, with small patch of golden pollen posteromesially; abdominal tergites 1-3 usually with posterior pollinose bands; band on tergite 1 usually complete; bands on tergites 2-3 usually broken in middle; tergite 4 sometimes with pollinose patch in posterolateral corner, rarely with complete posterior band; tergite 5 rarely with pollinose patch in posterolateral corner; tergites 6-7 lacking pollen; sternites 2-6 mostly devoid of pale pollen, but sternite 2 or sternites 2-3 sometimes with posterolateral pale yellow pollinose patches; Pennsylvania and Georgia west to Oklahoma and Texas

Ceraturgus (Ceraturgus) elizabethae Brimley

- Postalar callus mostly white to golden yellow pollinose; abdominal tergites 1-6 or 1-7 with complete posterior pollinose bands; sternites 2-6 almost completely pale pollinose or with broad posterior pale yellow pollinose bands

5 Male face white tomentose; male mystax sordid white; female face pale golden tomentose; female mystax golden yellow; frons mostly white or pale yellow pollinose, except at midline; postgena, stipes and palpi with dense vestiture of white hair-like setae; male sternites $2-6$ almost completely white pollinose; female sternite 2 completely or almost completely yellow pollinose; Midwest.

.Ceraturgus (Ceraturgus) cruciatus (Say)

- Male and female face rich golden tomentose laterally, brown centrally; male and female mystax brown or bronze; frons mostly shining dark brown, except for golden brown pollinose band along inner eye margin; postgena, stipes and palpi with dense vestiture of dark brown or black hair-like setae; male sternites 2-6 mostly brown, with elongate yellow pollinose patches in posterolateral corners; female sternite 2 with complete or broken posterior yellow pollinose band; southern Ontario, Maine and South Carolina west to Michigan and Mississippi. Ceraturgus (Ceraturgus) fasciatus Walker

6 Occipital setae golden; femora and tibia mostly yellow with dark brown or black apices; small species; 
rarely over $11 \mathrm{~mm}$ long; Massachusetts to Georgia and Michigan

Ceraturgus (Ceraturgus) aurulentus (Fabricius)

- Occipital setae black; femora wholly dark brown or black; tibiae variable; larger species, usually over 12 $\mathrm{mm}$ long

7 Tibiae mostly yellow, dark brown or black apically; Vermont and Massachusetts west to New York and West Virginia Ceraturgs (Ceraturgus) similis Johnson

- Tibiae black; North Carolina, South Carolina, Georgia, and Tennessee

Ceraturgus (Ceraturgus) nigripes Williston

8 Scutum white pollinose laterally and posteriorly; smaller species, rarely over $14 \mathrm{~mm}$ long; wings nearly hyaline; femora, tibiae, and tarsi dark brown to black; female abdominal tergites 1-5 with white posterior pollinose band; Texas and Oklahoma Ceraturgus (Ceraturgopsis) oklahomensis (Bromley)

- Scutum yellow or white pollinose laterally and posteriorly; larger species, usually over $14 \mathrm{~mm}$ long; wings distinctly infuscated; femora, tibiae, and tarsi yellow to reddish brown; female abdominal tergites 1-5 or 1-7 with yellow posterior pollinose bands; southeastern United States

9 Dark brown, non-pollinose areas of the scutum lacking hair-like setae, except for a narrow median longitudinal line and prescutellar patch of short, reclinate, golden hair-like setae; male sternites 1-7 mostly covered with yellow pollen; only female abdominal tergites 1-5 with yellow posterior pollinose bands; female tergites 6-7 shining; larger species, 17.9-19.5 mm long; southeastern United States

Ceraturgus (Ceraturgopsis) cornutus (Wiedemann)

- Scutum covered with short, reclinate, golden hair-like setae throughout, including non-pollinose areas; male sternites 1-2 mostly covered with yellow pollen; male sternites 3-7 mostly shining brown, with yellow pollinose lateral and posterior margins; female abdominal tergites 1-7 with yellow posterior pollinose bands; smaller species, 13.7-17.6 mm long; Florida. Ceraturgus (Ceraturgopsis) johnsoni Martin

\section{Subgenus Ceraturgus}

Both Johnson (1903) and Back (1909) described Ceraturgus as having a densely pubescent third flagellomere. Indeed, both sexes of all species in this subgenus have conspicuous long pubescence densely covering the third flagellomere. This character and the fact that the third flagellomere is as long as or longer than scape and pedicel combined are sufficient to separate the species of this subgenus from those of subgenus Ceraturgopsis.

\section{Ceraturgus (Ceraturgus) mitchelli Brimley}

(FIGS 1A, 1B, 2A, 3)

Ceraturgus mitchelli Brimley, 1924: 9.

Type material examined. Holotype, male, UNITED STATES, "Swannanoa, NC, 26 May 1923, T. B. Mitchell”, “Type No. 26830 U.S.N.M.” [red label], "TYPE Ceraturgus mitchelli Brimley” [white label with double red outline], USNM.

Additional material examined. UNITED STATES. FLORIDA. Liberty County: Torreya State Park, 28 April 1952, ơ , G. S. Walley, CNC; 13 May 1968, 우, G. H. Heinrich, FSCA; 15 May 1968, ơ , H. V. Weems, Jr., FSCA; 9-17 May 1968, $\propto^{\star}$, 우, H. V. Weems, Jr., FSCA; 1 May 1973, $\propto^{\star}$, 우, H. V. Weems, Jr. FSCA; 22 April 1982, o , L. L. Pechuman, CUIC.

GEORGIA. County unknown: 우, H. R. Morrison, USNM. 
KENTUCKY. Rowan County: Daniel Boone National Forest, Ramey Cr., 1 June 1992, 2 우, B. C. Kondradieff, CSUC; Ramey Cr., 0.5 mi. off CR-801, 1 June 1992, 2 o $^{\star}$, B. C. Kondratieff, CSUC; Ramey Cr., 28 May 1993, ox , Kondratieff \& Kirchner, BYU; Ramey Cr., 28 May 1993, 7 ox , 7 우, Kondradieff \& Kichner, CSUC; Ramey Cr., Cave Run Lake, 25 May 2002, $50^{\star}$, 우, B. Kondradieff \& R. F. Kichner, CSUC.

LOUISIANA. Tangipahoa Parish: 6 April 1979, ㅇ, R. L. Stone, LSAM.

MICHIGAN. Ingham County: East Lansing, 2 August 1937, ㅇ, F. Parmelee, USNM.

NEBRASKA. Douglas County: Omaha, 17 June 1923, 우, R. A. Leussler, EMEC.

NORTH CAROLINA. Buncombe County: Black Mountain, 6 June 1927, ㅇ, J. C. Crawford, NCSU.

OHIO. Ashland County: Mohican State Park, 7 June 1982, ㅇ, CMNH. Franklin County: Columbus, 23 June 1930, $o^{x}$, H. W. Smith, OSU. Geauga County: Bainbridge, 22 June 1935, ox , M. E. Crago, OSU. Holmes County: Holmesville, 17 June 1937, o* , ㅇ, R. T. Everly, OSU; 20 June 1937, o pinned with a silphid (Nicrophorus marginatus Fabricius), R. T. Everly, OSU. Stark County: Massillon, 20 June 1961, ox , L. R. Ertie, KSUC. Summit County: 12-24 June 1936, L. J. Lipovsky, ox, o (examined by JW, now apparently lost). Summit County: 11 June 1937, 4 ox , L. J. Lipovsky, SEMC; $3 \sigma^{x}$, L. J. Lipovsky, USNM; 12 June 1937, $o^{x}$, L. Lipovsky, FSCA; ㅇ, o , L. J. Lipovsky, SEMC; ${ }^{\star}$, L. J. Lipovsky, USNM; 24 June 1937, 우, L. Lipovsky,

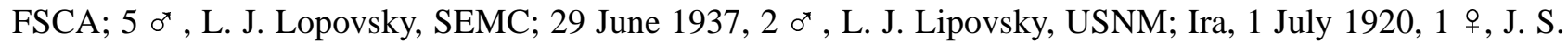
Hine, OSU. Wayne County: 4 June 1948, 우 R. H. Weesel, CSCA; East Union Township, 15 June 1937, 2 우, D. J. Borror \& D. W. Jenkins, OSU, USNM; Wooster, 15 June 1937, o $^{\star}$, ㅇ, D. Jenkins \& D. J. Borror, OSU; 18 June 1954, ㅇ, W. E. Goslin, OSU; 30 May 1957, ㅇ, W. E. Goslin, OSU.

PENNSYLVANIA. Allegheny County: Wilmerding, 13 June 1914, $o^{x}$, Zahrobsky, CLEV; 25 June, $o^{x}$, Zahrobsky, CLEV. Butler County: Slippery Rock, 21 June 1929, ơ , CMNH. Centre County: State College, 23 June 1934, ㅇ, V. R. Haber, PSUC. Clearfield County: Shawville, 10 July 1940, 1 우, J. Bauer, CMNH. Monroe County: ca. 2 mi. S of Bushkill, 10 June 1983, ox , C. S. Bergson, ANSP.

TENNESSEE. Blount County: Great Smoky Mountains National Park, Cade's Cove, 1-6 June 1979, ox , Sharkey \& Johnson, MCZ. Morgan County: Burrvillle, 25 May 1950, 우, B. Benesh, FMNH; 1 June 1953, 우, B. Benesh, CUIC; 16 May 1954, + , B. Benesh, FMNH; 8 June 1954, + , B. Benesh, FMNH; 15 May 1955, o B. Benesh, FMNH; 3-6 June 1958, 2 ㅇ, B. Benesh, FMNH; 14-16 June 1958, 2 ㅇ, B. Benesh, FMNH.

TEXAS. Bastrop County: Lost Pines Biological Station, Stengl Ranch, between Buescher and Bastrop State Parks, 15-16 April 1994, 우 C. R. Nelson, BYU; Stengl Ranch, near Buescher State Park, 17 April 1993, 2 ㅇ, C. R. Nelson \& G. I. Baird, BYU. Brazos County: College Station, 11 April 1918, ㅇ, H. J. Reinhard, TAMU. Colorado County: 11 April 1922, ㅇ, G. Wiley, CAS. Dallas County: 19 April 1936, ox , Cheatum, USNM; Dallas, ㅇ, MCZ. Montague County: Forestburg, 30 April 1942, 2 ๙ $^{\star}$, 우, L. H. Bridwell, USNM; 18 May 1942, ox , L. H. Bridwell, USNM; 20 May 1942, , L. H. Bridwell, USNM; 30 May 1942, ㅇ L. H. Bridwell, USNM. Van Zandt County: Wills Point, 29 April 1937, o* , ㅇ, R. W. Dawson, USNM.

Male. Body length: 15.9-19.5 mm (mean \pm S.D.: $18.1 \pm 0.9 ; \mathrm{N}=24)$.

Head. Width 1.6 times eye height. Face white tomentose. Frons, vertex, postcranium, and gena white pollinose; postcranium and gena only thinly pollinose; ocellar tubercle and narrow midfrontal area immediately below ocellar tubercle bare, shining black. Face with mystax of long white setae confined to lower third; upper face with shorter white setae reaching to antennal bases. Frons laterally with short, thin, white setae. Ocellar triangle tuberculate, with about 14-16 long white setae. Postocular setae white, many with proclinate apices. Postgena and stipes with dense vestiture of long, slender, apically crinkled, white hair-like setae. Proboscis dark brown or black, laterally compressed, about 3.3 times as long as deep, deepest near base, tapered to rounded apex. Palpal segments about equal in length, dark brown, both with long, pale hair-like setae. Antenna $4.3 \mathrm{~mm}$ long, dark brown or black; scape shining, with pale lateral setae along entire length; pedicel dull, with pale dorsolateral and ventrolateral setae at apex; flagellomeres dull; first flagellomere dorsally with only 2-3 short, inconspicuous, pale, proclinate setae; antennomere:scape ratios 1.0:0.8:2.9:0.5:2.2.

Thorax. Cervical sclerites black in ground color, densely white pollinose, with dense vestiture of long, slender, apically crinkled, white hair-like setae. Pronotum white to pale yellow pollinose, with dense pile of 
long, slender, apically crinkled, white setae covering antepronotum and with lateral patch of shorter, straight, white setae on postpronotum; postpronotal lobe thickly white pollinose, covered with long, slender, erect white setae. Propleuron white pollinose, with dense vestiture of long, declinate, white hair-like setae on proepisternum and reclinate hair-like setae on anterior portion of proepimeron. Prosternum thinly white pollinose, lacking setae or hair-like setae. Scutum black in ground color, with continuous, broad, white pollinose, lateral and posterior band extending from postpronotal lobe to postalar lobe and across prescutellar edge of scutum; with central subshining vitta extending from pronotum nearly to scutellum, divided by narrow brown pollinose vitta along midline, flanked by pale pollinose bands extending and tapering from anterior end of scutum to transverse suture; with pair of broad posterolateral subshining black bare patches, divided by narrow line of white pollen along transverse suture, reaching from behind postpronotal lobes almost to scutellum; subshining black areas of scutum mostly devoid of vestiture of short or long setae, except for patch of long hair-like setae between transverse suture and scutellum; pollinose areas of scutum with vestiture of shorter, hair-like setae; lateral margin of scutum, in addition to several weaker setae, with 3-4 strong, pale presutural setae and 8-12 strong, pale postsutural, supra-alar setae. Postalar callus mostly white pollinose, with short, pale hair-like setae laterally and long, strong, pale reclinate setae posteriorly. Scutellum black in ground color, sparsely white pollinose on disc and margin, with about 8-12 moderately strong, long, erect pale marginal setae longer than or equal to length of scutellum and several marginal hair-like setae. Mediotergite shining black; anatergite thickly white pollinose; katatergite white pollinose, with fan of long, slender, apically crinkled, white hair-like setae. Most mesopleural sclerites at least partly white pollinose, but pollen sparse or lacking on lower anepisternum, lower katepisternum, lower and posterior anepimeron, and meron, these areas appearing shining or dull black. Posterior half of anepisternum covered with long, fine, golden, apically crinkled hair-like setae; dorsal hair-like setae declinate, ventral hair-like setae reclinate. Anterior basalare brown; posterior basalare white pollinose. Katepisternum with dorsal line of fine, pale hair-like setae. Anepimeron, katepimeron, and meron lacking stout setae or hair-like setae. Basal swelling of pleural wing process white pollinose. Subalar sclerite brown. Metepisternum and metepimeron white pollinose; metepimeron with long, fine, apically crinkled, pale hair-like setae.

Legs. Coxae lightly dusted with white pollen. Prothoracic and mesothoracic coxae densely covered with long, slender, white, apically crinkled hair-like setae on anterior and lateral surfaces. Metathoracic coxa with similar hair-like setae anteroventrally and posterolaterally. All femora shining black except for brownish yellow extreme apices, with circlets of several stout, pale setae near apex; prothoracic femur with $0-1$ stout, pale seta anteriorly near middle and 1-3 pale posterodorsal setae near apex; mesothoracic femur with 2 stout, pale setae anteriorly near middle and 3-4 pale posterodorsal setae near apex; metathoracic femur with anterior row of 5-8 white bristles and 1-2 pale posterodorsal setae near apex. Prothoracic tibia mostly yellow, with anterodorsal and posterodorsal row of short pale setae and posteroventral row of long pale setae; mesothoracic tibia variable in color, usually mostly yellow with brown anteroventral patch, sometimes mostly yellow with small apical brown or black ring, rarely completely black, with anterodorsal, antertoventral, posterodorsal, and posteroventral rows of long, pale, stout setae; metathoracic tibia black, except for brownish yellow extreme base, with dorsal and anterior rows of long, pale setae and ventral row of long pale to dark brown setae. Prothoracic tarsi with all tarsomeres brownish yellow. Mesothroacic tarsi with all tarsomeres brownish yellow basally, black apcially. Metathoracic tarsi with tarsomeres concolorous black. First tarsomere longer than or equal to length of second and third combined. All claws black with golden brown base. Prothoracic pulvilli brown; mesothoracic and metathoracic pulvilli yellow.

Wing (FIG.1A). 11.8-16.1 mm long (mean \pm S.D.: $14.0 \pm 0.8 ; \mathrm{N}=24$ ). Membrane hyaline or very lightly infuscated apically, infuscated darker brown basally; lightly infuscated in cells bm, cup, and $\mathrm{a}_{1}$, most heavily infuscated in cells $\mathrm{c}$ and sc, along anterior margin of cell br, at base of cells $r_{1}$ and $r_{2+3}$, and around crossvein $r$ m. Halter with stem and knob brown or brownish yellow. 
Abdomen. Tergites 1-5 shining black in ground color, with broad posterior white pollinose transverse band; each pollinose band complete, mostly uniform in width, but much wider at lateral margin. Tergite 1 with many long pale hair-like setae anterolaterally, many long pale setae posterolaterally. Tergite 2 with many long, slender, pale hair-like setae laterally; tergites 3-6 with shorter pale hair-like setae. Tergite 6 shining black, with white pollinose posterolateral angles. Tergite 7 shining black. Sternites 1-6 with heavy dusting of white pollen, and with some long, slender, pale hair-like setae. Terminalia shining black, with many long dark hairlike setae; gonocoxite and gonostylus as in Fig. 2A.
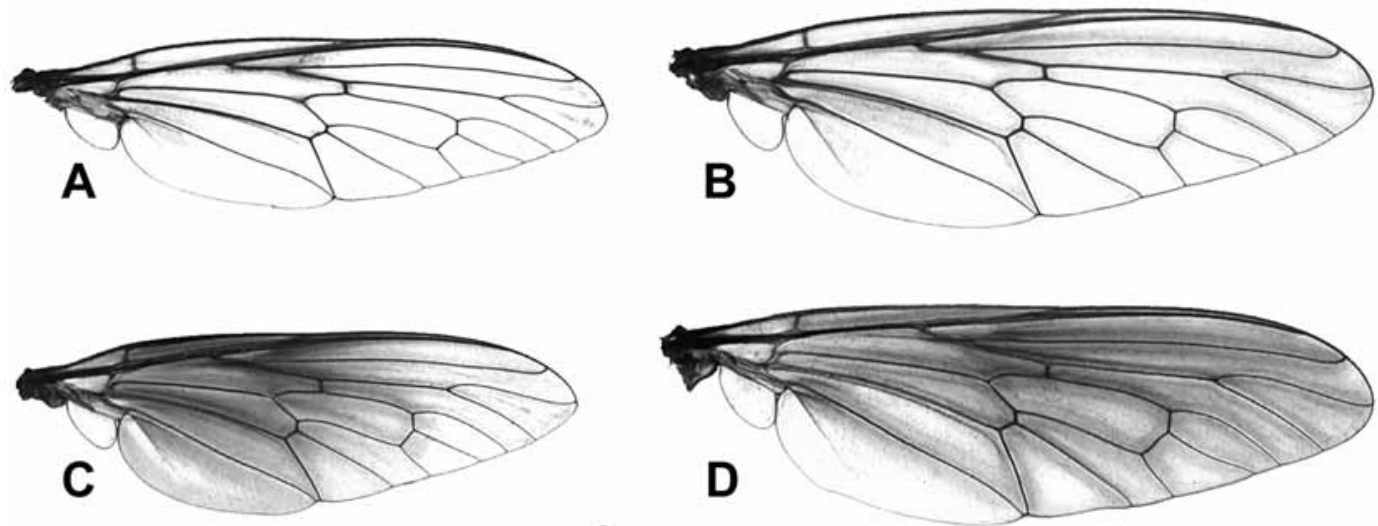

$1 \mathrm{~cm}$
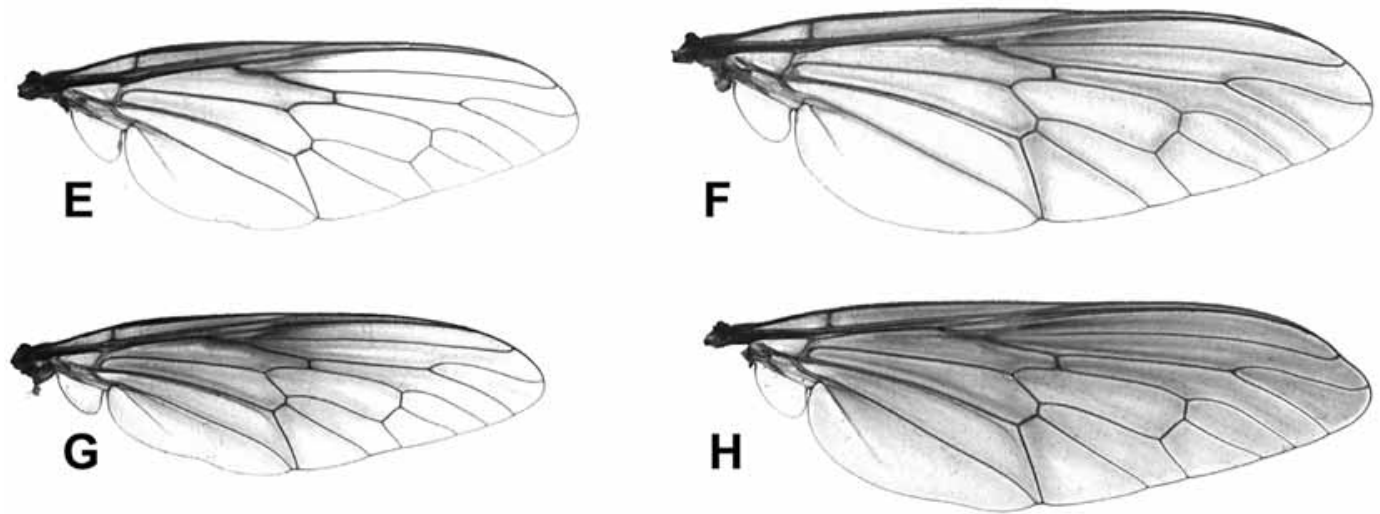

FIGURE 1. Ceraturgus, right wing, dorsal view: A, B, C. mitchelli, male and female, respectively; C, D, C. elizabethae, male and female, respectively; E, F, C. cruciatus, male and female, respectively; G, H, C. fasciatus, male and female, respectively.

Female. Similar to male.

Body length: $17.2-23.7 \mathrm{~mm}$ (mean \pm S.D.: $20.8 \pm 1.6 ; \mathrm{N}=18$ ).

Head. Width 1.6 times eye height. Antenna $4.3 \mathrm{~mm}$ long; antennomere:scape ratios: 1.0:0.8:2.9:0.5:2.1.

Wing (FIG.1B). 14.3-19.0 mm long (mean \pm S.D.: $17.1 \pm 1.4 ; \mathrm{N}=18$ ). Membrane more extensively infuscated than in male; mostly lightly infuscated brown, darker in cells $\mathrm{c}$ and $\mathrm{sc}$, at base of cells $\mathrm{r}_{1}$ and $\mathrm{r}_{2+3}$, and around crossvein $\mathrm{r}-\mathrm{m}$.

Legs. Femora variable in color, usually mostly black with small apical yellow ring, sometimes mostly black with broad to narrow apical and basal reddish brown rings, rarely mostly reddish brown, with central black patches. Mesothoracic tibia variable in color, usually mostly yellow with small brown apical ring, sometimes mostly yellow with anteroventral brown or black patch, sometimes completely yellow. All pulvilli yellow.

Abdomen. All tergites shining black or dark brown in ground color. Tergites 1-4 with broad posterior white pollinose transverse band; each pollinose band complete, mostly uniform in width, but much wider at 
lateral margin. Tergite 6-8 wholly or mostly shining black; tergites 5-6 and sometimes tergite 7 with small posterolateral white pollinose patch. Sternites 1-8 shining black or dark brown in ground color; sternites 1-3 heavily dusted with white pollen; sternites $4-5$ variable, usually only partially pollinose, especially laterally and posteriorly, but sternite 4 sometimes wholly pollinose; sternites 6-8 lacking pollen.

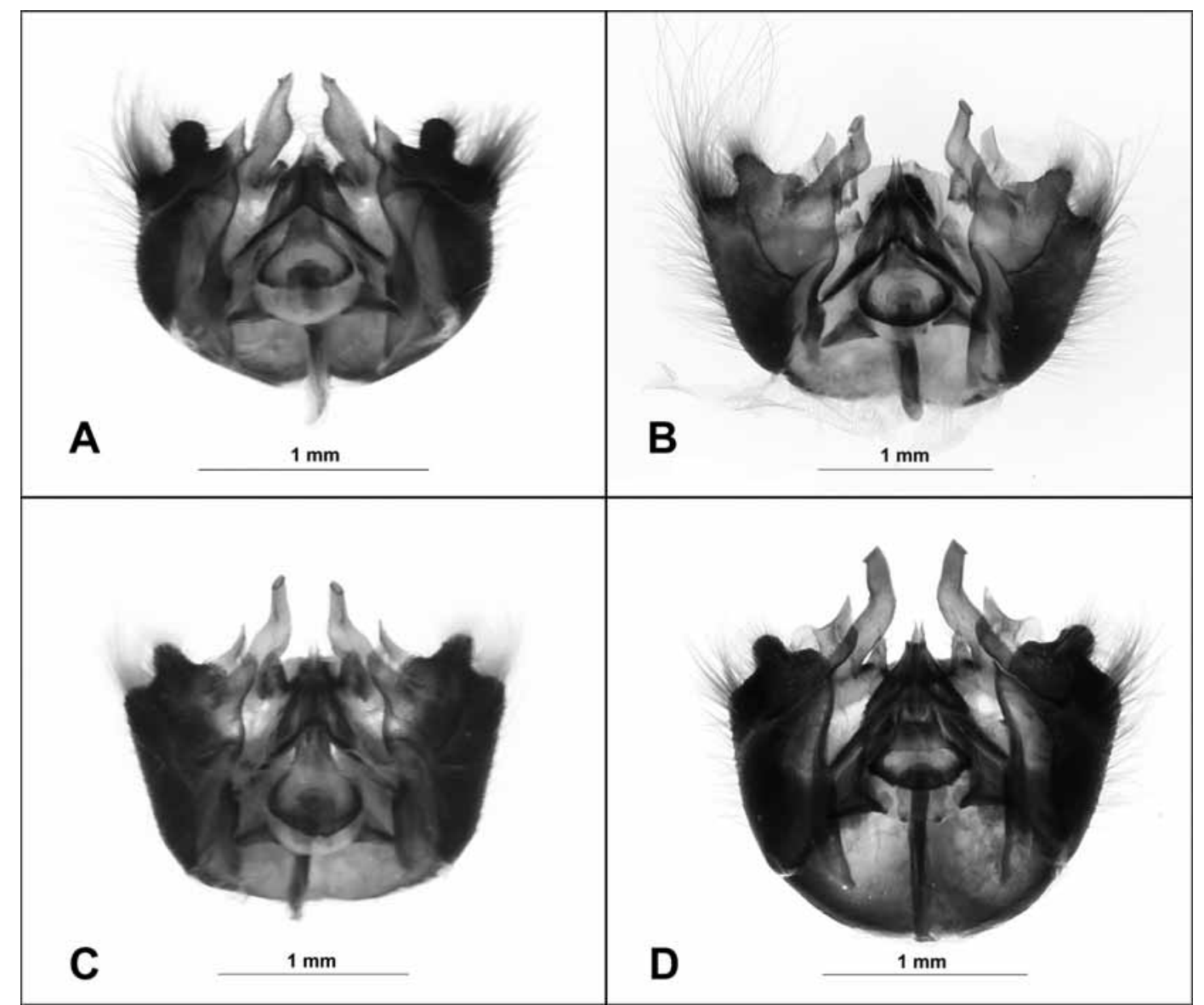

FIGURE 2. Ceraturgus male genitalia, epandrium removed, anterodorsal view: A, C. mitchelli; B, C. elizabethae; C, C. cruciatus; D, C. fasciatus.

Distribution (Fig. 3). Pennsylvania and Florida west to Nebraska and Texas.

Discussion. Ceraturgus mitchelli can be distinguished from other North American members of the genus by the fact that the posterior pollinose bands on male tergites 2-5 and female tergites 2-4 extend forward at the lateral margins of the tergites. The bands are thus widest at the lateral margins in this species only. This species has been commonly misidentified as $C$. dimidiatus, presumably because Back's (1909) key leads to this species, which is now placed in the genus Taracticus.

Most females from Texas differ from typical females in that the femora are mostly black with broad to narrow apical and basal reddish brown rings. This, plus the odd, seemingly patchy distribution of the species, with most known specimens collected in Pennsylvania, Ohio, Kentucky, Tennessee, and eastern Texas, suggests that we might be identifying more than one species as $C$. mitchelli. However, comparison of the male genitalia of one specimen from Wilmerding, Allegheny County, Pennsylvania, with those of a specimen from Forestburg, Montague County, Texas (FIG. 2A), has revealed no significant difference.

Specimens from Florida, Louisiana, and Texas have been collected from early April to late May. Most specimens from more northerly states have been collected from mid May to late June, although there is one record of specimen collected in early August in Michigan. One female from Holmesville, Holmes County, Ohio, is pinned with its presumed prey, a specimen of Nicrophorus marginatus Fabricius (Coleoptera: Silphidae) prey. 


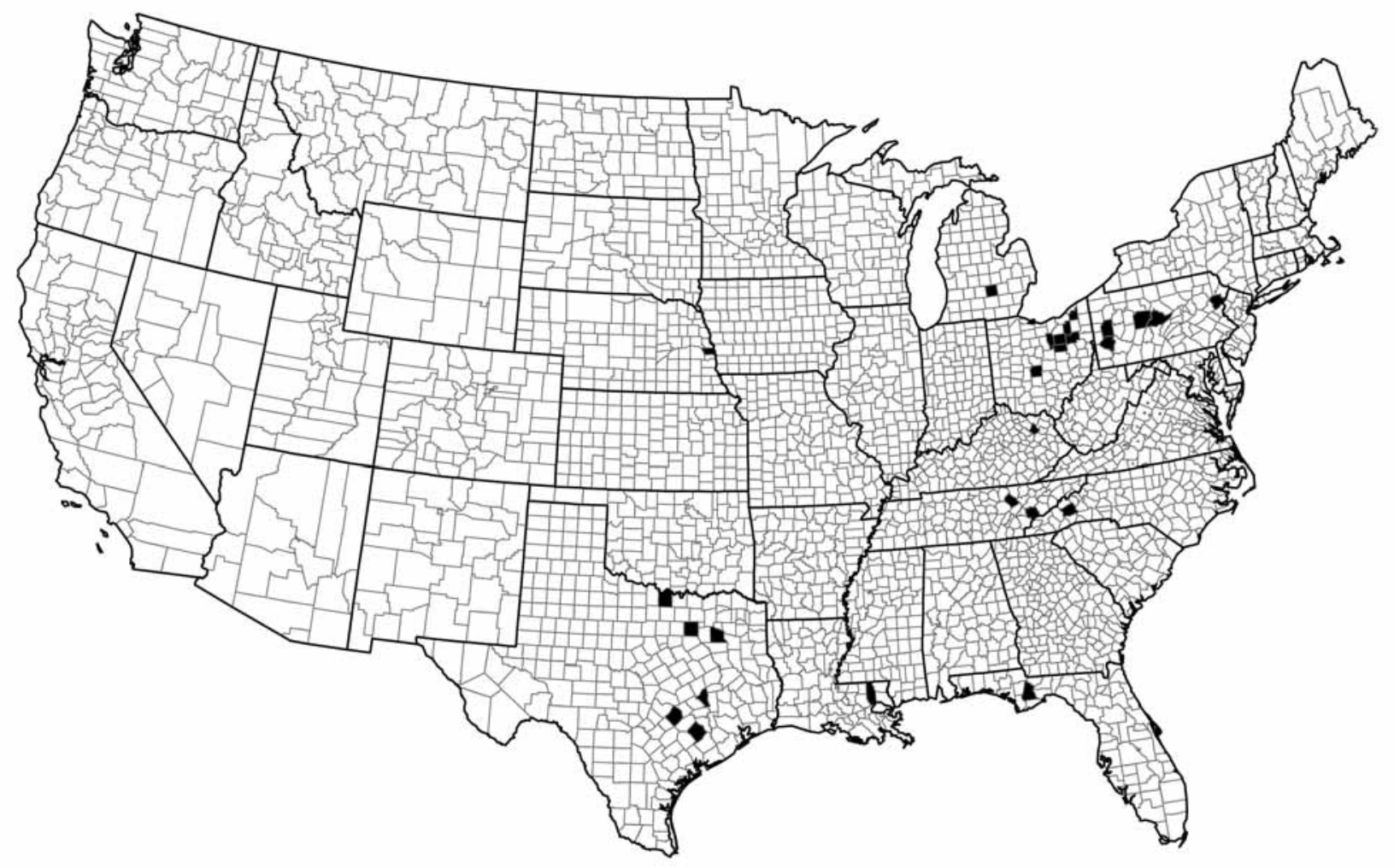

FIGURE 3. Distribution of Ceraturgus mitchelli by county and parish.

\section{Ceraturgus (Ceraturgus) elizabethae Brimley}

(FIGS 1C, 1D, 2B, 4)

Ceraturgus elizabethae Brimley, 1924: 8.

Type material examined. Holotype, male, UNITED STATES: "Raleigh, N. C., VI 13 1922, T. B. Mitchell", "A 우 in coitu A ox", "2.", "Type No. 26831 U.S.N.M." [red label], "Type Ceraturgus elizabethae ox Brimley", USNM. Allotype, female, UNITED STATES: "Raleigh, N. C., VI 13 1922, T. B. Mitchell”, "A ox in coitu A ○”, Allotype No. 26831 U.S.N.M.” [red label]. Paratype, female, UNITED STATES: "Raleigh, N.C., 21 June 22, C. S. Brimley", "NCSU, ex NCDA\&CS, 2000", "PARATYPE, Ceraturgus elizabethae Brimley" [red label, handwritten], NCSU.

Additional material examined. UNITED STATES. ALABAMA. Monroe County: Haines Island Park, 31 43 '23"N 37²8'10"W, 26-31 May 1995, ơ , J. A. McGown, MEM.

ARKANSAS. Clay County: Chalk Bluff, 30 June 2005, ㅇ, N. Lavers, UAAM. Craighead County: Jonesboro, woods, 26 June 2005, ㅇ, N. Lavers, UAAM. Lee County: St. Francis National Forest, 22-23 June 1973, ㅇ, NCSU; 9 June 2003, ${ }^{\star}$, N. Lavers, UAAM. Washington County: Fayetteville, 12-20 June 1973, ㅇ, E. V. Gage, TAMU.

DISTRICT OF COLUMBIA. Chain Bridge, 24 July 1913, ㅇ, H. B. Kirk, USNM.

GEORGIA. Clarke County: 3 July 1983, ㅇ, E. Vargo, BYU; Whitehall Forest 14-18 June 1979, R. H. Turnbow, Jr., FSCA; Whitehall Forest, 5-8 July 1979, insect flight trap, ㅇ, R. H. Turnbow, Jr., CSCA. Thomas County: Thomasville, 18 May 1940, $\sigma^{x}$, W. H. Thames, Jr., UGCA.

INDIANA. Harrison County: July 8, 1969, 우, H.R. Rush, CSCA; Owen County: Spencer, 11 July 1925, 2 ${ }^{\star}$, E. G. Anderson, USNM, UMRM; 12 July 1925, ㅇ, E. G. Anderson, UMRM. 
KENTUCKY. Hardin County: Fort Knox, 11 July 1963, ox , P. E. Adams, FSCA. Rockcastle County: Livingston, ${ }^{\star}$, H. G. Hubbard, USNM. MARYLAND. Prince George's County: Beltsville, 16 July, ㅇ, F. R. Cole, USNM.

MISSISSIPPI. Grenada County: Grenada, 22 June 1971, ㅇ, C. Bryson, MEM; T21N R2E, Sec. 12, 13N \& R3E, Sec 7S, 18N, 5-11 June 1991, ox, ㅇ, R. L. Brown, MEM.

MISSOURI. St. Louis County: Ranken, 4 July 1935, , E. P. Meiners, UMRM.

NORTH CAROLINA. Haywood County: Crestmont, 18 July 1922, 우 T. H. Hubbell, UMMZ. Nash County: Rocky Mount, 25 June 1924, ㅇ, A. M. Woodside, NCSU. Wake County: 16 June 1955, ㅇ, H. V.

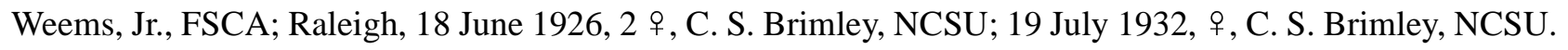
OHIO. Hocking County: Laurel Township, 20 June 1937, ox, E. S. \& J. S. Thomas, OSU.

OKLAHOMA. Ottawa County: Wyandotte, 4 June 1931, ㅇ, W. D. Davis, USNM. Pushmataha County: Neshoba, 15 June 1934, 2 ㅇ, A. E. Pritchard, USNM.

PENNSYLVANIA. County unknown: Germantown, 2 July 1908, 우, USNM. Centre County: State College, 12 July 1928, 우, C. B. Lewis, MCZ.

SOUTH CAROLINA. Pickens County: Rocky Bottom, 9 July 1931, 우, F. Sherman, CUAC.

TEXAS. Brazos County: College Station, 21-25 April 1981, ㅇ, R. Wharton \& R. Turnbow, TAMU. Dallas County: Dallas, $o^{x}, \mathrm{MCZ}$.

VIRGINIA. Arlington County: Glencarlyn, 10 July 1919, ㅇ, USNM; 30 June, ㅇ, MCZ. Fairfax County: Falls Church, ㅇ, MCZ; Great Falls, 27 June 1913, ㅇ, S. A. Rohwer, USNM; Scotts Run, 17 July 1917, ox , L. O. Jackson, USNM. Nelson County: 18 July 1913, 우, W. Robinson, USNM; 20 June 1922, 우, W. Robinson, USNM; 2 July 1927, 오, W. Robinson, USNM; 11 July 1928, ㅇ, W. Robinson, USNM.

WEST VIRGINIA. Pocahontas County, Charles Creek, near Cranberry Glades, 3490 ft., 1 July 1967, + , FSCA.

Male. Body length: $14.0-18.5 \mathrm{~mm}$ (mean \pm S.D.: $17.3 \pm 1.8 ; \mathrm{N}=8)$.

Head. Width 1.6 times eye height. Face golden tomentose, with mystax of long golden brown setae confined to lower third; upper face with shorter golden brown setae almost reaching to antennal bases. Frons and vertex, including ocellar tubercle, shining dark brown, except for narrow golden pollinose line along inner compound eye margins. Frons covered with short, thin, golden brown setae, except along midline. Postcranium dark brown, except for broad golden pollinose bands along outer compound eye margins. Gena dark brown. Ocellar triangle tuberculate, with about 12-16 long yellow or brown setae. Postocular setae pale yellow, many with proclinate apices. Postgena and stipes with dense vestiture of long, slender, apically crinkled, dark brown or black hair-like setae. Proboscis brown, laterally compressed, about 4.6 times as long as deep, deepest near base, tapered to rounded apex. Palpal segments about equal in length, dark brown, both with long, golden brown hair-like setae. Antenna $6.1 \mathrm{~mm}$ long; scape shining reddish brown, with pale lateral setae along entire length; pedicel dull reddish brown, with pale dorsolateral and ventrolateral setae at apex; flagellomeres dull black; antennomere:scape ratios 1.0:0.9:3.3:0.6:4.4.

Thorax. Cervical sclerites dark brown in ground color, thinly golden pollinose, with dense vestiture of long, slender, apically crinkled, brown hair-like setae. Pronotum thinly golden brown pollinose, with dense pile of long, slender, apically crinkled, brown setae covering antepronotum and with lateral patch of shorter, straighter, paler setae on postpronotum; postpronotal lobe shining golden brown in ground color, thickly golden pollinose anteriorly, covered with long, slender, erect pale setae posteriorly. Propleuron brown pollinose, with dense vestiture of long, declinate, brown hair-like setae on proepisternum and reclinate hair-like setae on anterior portion of proepimeron. Prosternum thinly golden brown pollinose, lacking setae. Scutum shining brown in ground color, mostly devoid of pollen, but with narrow, golden pollinose line along transverse suture and broad, lateral, supra-alar golden pollinose band extending from postpronotal lobe almost to postalar callus, this band often weak between postpronotal lobe and transverse suture; with obscure, dark, central subshining vitta extending from pronotum nearly to scutellum, divided by narrow line of short, pale setae 
along midline; with pair of broad, dark, posterolateral subshining bare patches, divided by narrow line of golden pollen along transverse suture, reaching from behind postpronotal lobes almost to scutellum; subshining dark areas of scutum mostly devoid of vestiture of short or long setae, except for patch of long hair-like setae between transverse suture and scutellum; remainder of scutum with vestiture of shorter, hair-like setae; lateral margin of scutum, in addition to several weaker setae, with 1-2 strong, pale presutural setae and 6-7 strong, pale postsutural, supra-alar setae. Postalar callus shining golden brown in ground color; with short, pale hair-like setae laterally; long, strong, pale reclinate setae posteriorly; and small patch of golden pollen posteromesially. Scutellum dark brown in ground color, golden pollinose posteriorly on disc, devoid of strong, marginal setae, with several weak, pale marginal hair-like setae about equal to length of scutellum. Mediotergite shining dark brown; anatergite thickly golden pollinose; katatergite thinly golden pollinose, with fan of long, slender, apically crinkled, pale hair-like setae. Most mesopleural sclerites at least partly golden pollinose, but pollen sparse or lacking on most of anterior and ventral anepisternum, most of lower katepisternum, lower anepimeron, and meron, these areas appearing shining dark brown. Posterior half of anepisternum covered with long, fine, golden, apically crinkled hair-like setae; dorsal setae declinate, ventral setae reclinate. Anterior basalare brown; posterior basalare pale golden pollinose. Katepisternum with small dorsal patch of fine, pale hair-like setae. Anepimeron, katepimeron, and meron lacking setae. Basal swelling of pleural wing process golden brown pollinose. Subalar sclerite brown. Metepisternum and metepimeron golden pollinose; metepimeron with long, fine, apically crinkled, pale hair-like setae.

Legs. Coxae pale golden pollinose. Prothoracic and mesothoracic coxae densely covered with long, slender, pale, apically crinkled hair-like setae on anterior and lateral surfaces. Metathoracic coxa with similar hairlike setae anteroventrally and posterolaterally. All femora shining yellowish brown to reddish brown, darker dorsally than ventrally, with circlets of several stout, pale setae near apex; prothoracic femur with 1-2 stout, pale seta anteriorly on basal half; mesothoracic femur with 1-2 stout, pale setae anteriorly on basal half; metathoracic femur with anterior row of 4-5 pale bristles. Tibiae and tarsi wholly yellow. Prothoracic tibia with anterodorsal and posterodorsal row of short pale setae and posteroventral row of long pale setae; mesothoracic tibia with anterodorsal, anteroventral, and posteroventral rows of long pale setae and posterodorsal row of short, pale setae; metathoracic tibia with anterior and dorsal rows of short pale setae and ventral row of long, pale setae. Length of first tarsomere longer than or equal to length of second and third combined. All claws black with golden brown base. Prothoracic pulvilli brown; mesothoracic and metathoracic pulvilli yellow.

Wing (FIG. 1C). 11.1-15.0 mm long (mean \pm S.D.: $13.5 \pm 1.2 ; \mathrm{N}=8$ ). Membrane lightly infuscated apically, darker brown basally; lightly infuscated in cells cup, and $\mathrm{a}_{1}$, most heavily infuscated in cells $\mathrm{c}$ and sc, br, $\mathrm{bm}$, at base of cells $r_{1}$ and $r_{2+3}$, and around crossvein $r-m$. Halter with stem and knob brown or yellowish brown.

Abdomen. Tergites 1-3 shining dark brown or black in ground color, with broad posterior pale yellow pollinose transverse band; each pollinose band mostly uniform in width, but narrowed at lateral margin and narrowed or obliterated at midline. Tergites 4-6 shining dark brown or black anteriorly, shining reddish brown posteriorly, mostly lacking pollen, but tergite 4 sometimes with small amount of yellow pollen at posterolateral angles or at midline. Tergite 1 with many long pale hair-like setae anterolaterally, many long pale setae posterolaterally. Tergites 2-6 with shorter, pale hair-like setae. Sternites 1-6 mostly devoid of yellow pollen, but sternite 2 sometimes with patches of yellow pollen in posterolateral corners, and with some long, slender, apically crinkled, brown hair-like setae, especially dense on sternites 5-6. Terminalia shining yellowish brown or reddish brown, with many long brown hair-like setae; gonocoxite and gonostylus as in FIG. 2B.

Female. Similar to male.

Body length: $16.5-24.3 \mathrm{~mm}$ (mean \pm S.D.: $20.3 \pm 2.2 ; \mathrm{N}=15$ ).

Head. Width 1.6 times eye height. Mystax with long setae confined to oral margin. Antenna $6.0 \mathrm{~mm}$ long; antennomere:scape ratios: 1.0:0.8:3.4:0.6:4.2.

Thorax. Scutellum with marginal hair-like setae shorter than length of scutellum. 
Wing (FIG. 1D). 14.0-19.0 mm long (mean \pm S.D.: $16.8 \pm 1.3 ; \mathrm{N}=15$ ). Membrane more extensively infuscated than in male; mostly infuscated dark brown throughout, lighter in center of some cells.

Legs. Femora usually uniformly yellowish brown to reddish brown, rarely with dorsal side darker. All tibiae, tarsi, and pulvilli yellow.

Abdomen. All tergites shining reddish brown to dark brown in ground color; tergites 5-8 usually lighter in color than tergites $1-4$. Usually tergites $1-4$ with posterior pale yellow pollinose transverse band; pollinose band sometimes absent from tergite 4, or represented by small posterolateral pollinose patch; pollinose band complete on tergite 1 , usually narrowly or broadly interrupted at midline on tergites $2-4$, rarely complete or slightly notched at midline. Tergites 5-8 wholly or mostly shining black; tergite 5 sometimes with small posterolateral pale yellow pollinose patch. Sternites 1-2 brown pollinose; sternites 3-4 sometimes shining brown with broad posterior brown pollinose band, sometimes completely shining. Sternite 2 or sternites $2-3$ sometimes with posterolateral pale yellow pollinose patches; sternites 5-8 shining dark brown to reddish brown.

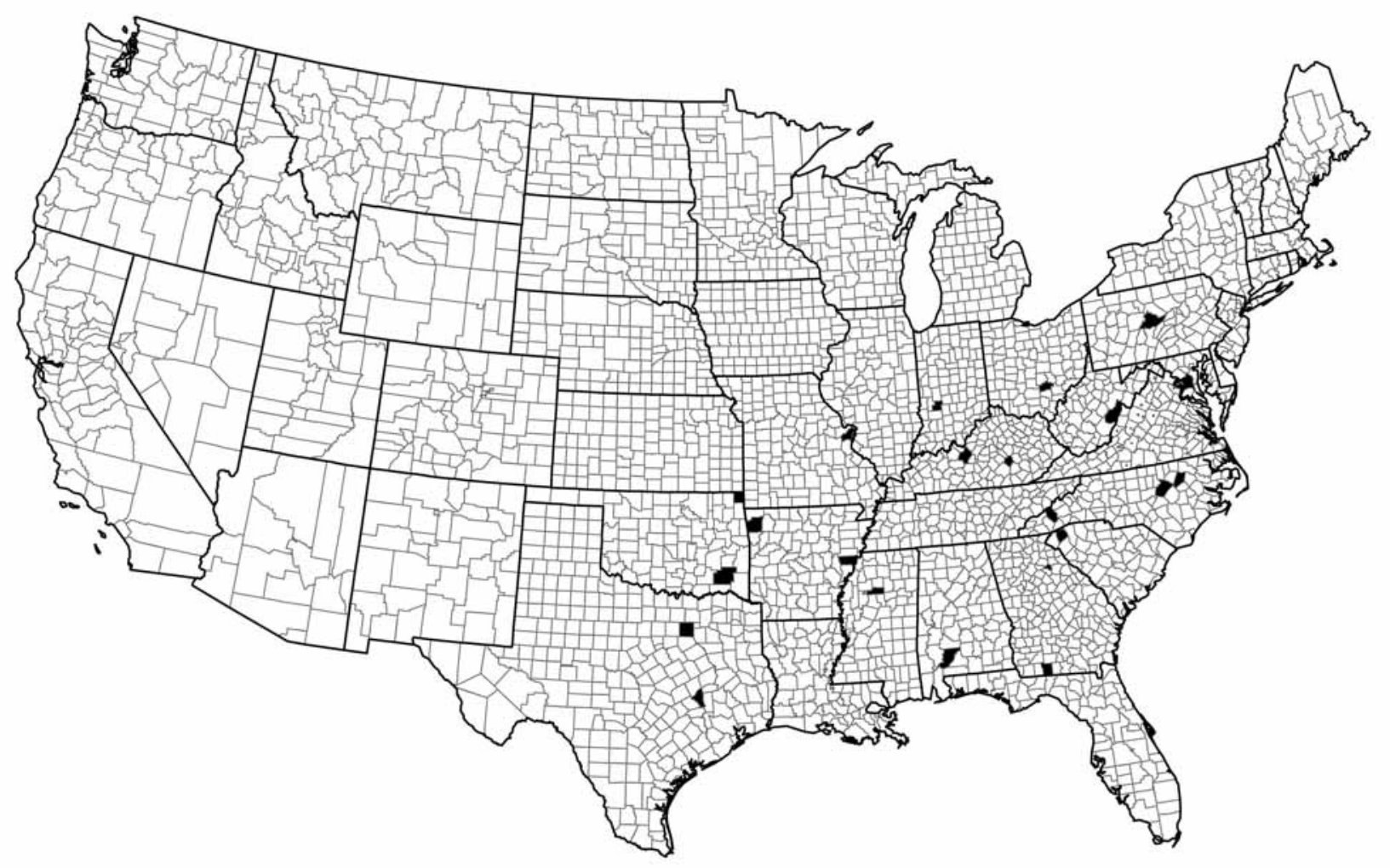

FIGURE 4. Distribution of Ceraturgus elizabethae by county.

Distribution (FIG. 4). Pennsylvania and Georgia west to Oklahoma and Texas.

Discussion. Many pinned specimens have become greasy, and the grease tends to obliterate the yellow color of the pollinose bands on tergites 1-3. However, in lateral view, with the light reflecting from an appropriate direction, it is possible to detect the dullness produced by the pollen.

Norman Lavers (personal communication) has provided some information about the specimens that he observed and collected in Arkansas. All were collected in upland sites well removed from running and standing water. The male collected in 2003 at St. Francis National Forest, Lee County, was found in a small island of saplings situated in the middle of a large grassy and weedy field. It was perched on a sapling, about one meter from the ground. The two individuals that he observed at Bell Slough Wildlife Management Area, Faulkner County, in 2005 were in glades, one perched on a small sapling and the other perched on low vegetation. The female collected at Jonesboro, Craighead County, in 2005, was in closed canopy woodland, perched on poison ivy leaves, carrying what appeared to be a small beetle. When disturbed, it flew down into the poi- 
son ivy and hung from a leaf by its forelegs. The female collected at Chalk Bluff, Clay County, in 2005, was also found on poison ivy under a closed forest canopy. Specimens of this species were sometimes observed in areas where sphecid wasps of the genus Tachytes were flying. The flies look quite similar to the wasps, which may serve as their mimicry models.

A few specimens from Georgia, Alabama, and Texas have been collected from late April to late May, but most specimens have been collected from mid June to mid July.

\section{Ceraturgus (Ceraturgus) cruciatus (Say)}

(FIGS 1E, 1F, 2C, 5)

Dasypogon cruciatus Say, 1823: 52.

Ceraturgus cruciatus: Brauer 1883: 56.

Type material. In his original description, Say (1823) simply stated, "Inhabits Arkansa." He did not elaborate on how many specimens he worked with, or what sex he saw. Osten Sacken (1878) indicated that the type was a female. According to Back (1909), the type is lost.

Additional material examined. UNITED STATES. ILLINOIS. Coles County: Charleston, May 1916, ox, INHS.

IOWA. Delaware County: Robinson, 15-24 July, ox, N. K. Bigelow, CNC; 22 June 1924, ㅇ, N. K. Bigelow, CNC. Story County: Ames, 1 July 1923, ㅇ, CNC; 26 June 1925, ㅇ, P. Spong, KSUC; 14 July 1931, 우, H. A. Scullen, CAS.

KANSAS. Ellis County: Fort Hays, 20 June 1871, ㅇ, J. A. Allen, MCZ. Norton County: 5 July 1925, 3 ox, H. J. Grady, CNC. Scott County: 19 June 1925, 우 H. Deay, CAS; 24 June 1925, 2 ox 3 우, H. Deay, SEMC; 25 June 1925, 우, R. H. Beamer, CNC; 25 June 1925, 7 ox $^{\star} 2$ 우, R. H. Beamer, CAS; 25 June 1925, ox , H. J. Grady, WSU; 25 June 1925, ㅇ, R. H. Beamer, TAMU. Sumner County: 1189 ft., 1916, 우, R. H. Beamer, WSU.

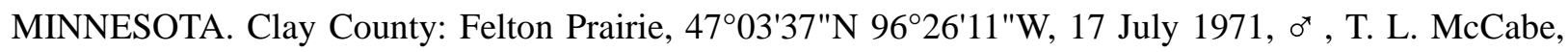
NYSM. Goodhue County: E. Frontenac, Lake Pepin, 29 May 1941, ox , USNM. Houston County: Winnebago Creek Valley, 3-4 mi. NE of Eitzen, 31 May 1941, ㅇ, E. L. Dery, UMSP.

MISSOURI. Laclede County: Mark Twain National, Forest, Gasconade River, Rt. 32, 1 mi. E of Falcon, 25 June 1989, 오, B. Kondratieff \& M. Harris, CSUC.

NEBRASKA. Douglas County: Omaha, 17 June 1923, 5 ㅇ, R. A. Leussler, CAS; 17 June 1923, 2 우, ox, R. A. Leussler, EMEC.

OKLAHOMA. Pushmataha County: Tuskahoma, 23 May 1928, ơ , L. A. Stephenson, CAS.

WISCONSIN. Crawford County: Gays Mills, 23 June 1942, ơ , IRCW. Dane County: 4 July 1917, ㅇ, W. S. Marshall, IRCW; 7 July 1917, ㅇ, W. S. Marshall, IRCW; 9 June 1952, ㅇ, J. T. Medler, IRCW; 21 June 1981, 우, W. Gould, IRCW; Madison, 6 June 1932, ox , CAS; June 1934, ox , ㅇ, IRCW; 13 June 1934, ㅇ, C. L. Fluke, CAS; 16 June 1949, ox, 2 우, W. J. Hanson, EMUS. Dodge County: Beaver Dam, 30 June 1909, ㅇ, W. E. Snyder, ANSP. Iowa County: Rt. 23, 1 mi. from Governor Dodge State Park, 26 June 1971, o [pinned with a pentatomid], L. J. Baker, ESUW. Sauk County: 3 mi. SE of Sauk City, 13 June 1962, , G. Lachmund, UGCA; Sauk Marsh, 25 June 1962, o o $^{\star}$ G. Lachmund, UGCA.

Male. Body length: 16.1-20.5 mm (mean \pm S.D.: $18.1 \pm 1.5 ; \mathrm{N}=10$ ).

Head. Width 1.5 times eye height. Face white tomentose, with mystax of long sordid white setae confined to lower third; upper face with shorter white setae almost reaching to antennal bases. Frons mostly white pollinose, covered with short, thin, white setae, except along midline. Vertex, including ocellar tubercle, shining dark brown, except for narrow white pollinose band along inner compound eye margins. Postcranium dark brown in ground color, broadly white pollinose. Gena shining brown, with sparse white pollen. Ocellar trian- 
gle tuberculate, with about 12-16 long white setae. Postocular setae white, many with proclinate apices. Postgena and stipes with dense vestiture of long, slender, apically crinkled, sordid white hair-like setae. Proboscis brown, laterally compressed, about 4.1 times as long as deep, deepest near base, tapered to rounded apex. Palpal segments about equal in length, dark brown, both with long, sordid white hair-like setae. Antenna 5.1-5.3 mm long; scape shining dark brown, with pale lateral setae along entire length; pedicel dull brown, with pale dorsolateral and ventrolateral setae at apex; flagellomeres dull black; antennomere:scape ratios 1.0:0.9:3.4:0.5:3.3.

Thorax. Cervical sclerites dark brown in ground color, thinly golden pollinose, with dense vestiture of long, slender, apically crinkled, white hair-like setae. Pronotum with white pollen heaviest on antepronotum, with dense pile of long, slender, apically crinkled, white setae covering antepronotum and with lateral patch of shorter, straighter, paler setae on postpronotum; postpronotal lobe yellowish brown or reddish brown in ground color, thickly white pollinose anteriorly, covered with long, slender, erect pale setae. Propleuron white pollinose, with dense vestiture of long, declinate, pale hair-like setae on proepisternum and reclinate hair-like setae on anterior portion of proepimeron. Prosternum sparsely white pollinose, lacking setae. Scutum black in ground color, with broad, white pollinose lateral and posterior band extending from postpronotal lobe to postalar lobe and across prescutellar edge of scutum, narrowed or divided at prescutellar edge; with central dull dark vitta extending from pronotum nearly to scutellum, divided by narrow brown or pale pollinose vitta along midline, flanked by pale pollinose bands extending and tapering from anterior end of scutum to transverse suture and small pale pollinose patches at level of transverse suture; with pair of broad posterolateral dull black bare patches, divided by transverse suture, reaching from behind postpronotal lobes almost to scutellum; dull black areas of scutum mostly devoid of vestiture of short or long setae, except for patch of long hair-like setae between transverse suture and scutellum; pollinose areas of scutum with vestiture of shorter, hair-like setae; lateral margin of scutum, in addition to several weaker setae, with 2-4 strong, pale presutural setae and 6-8 strong, pale postsutural, supra-alar setae. Postalar callus mostly pale pollinose with short, pale hair-like setae laterally and long, strong, pale reclinate setae posteriorly. Scutellum black in ground color, white pollinose posteriorly on disc, devoid of strong, marginal setae, with several pale hair-like setae on disc and margin; some marginal hair-like setae equal in length to length of scutellum. Mediotergite shining dark brown; anatergite heavily white pollinose; katatergite heavily white pollinose, with fan of long, slender, apically crinkled, pale hair-like setae. Most mesopleural sclerites at least partly white pollinose, but pollen sparse or lacking on most of lower anepisternum, most of lower katepisternum, lower anepimeron, and meron, these areas appearing shining dark brown. Posterior half of anepisternum covered with long, fine, pale, apically crinkled hair-like setae; dorsal setae declinate, ventral setae reclinate. Anterior basalare brown; posterior basalare white pollinose. Katepisternum with small dorsal patch of fine, pale hair-like setae. Anepimeron, katepimeron, and meron lacking setae. Basal swelling of pleural wing process white pollinose. Subalar sclerite brown. Metepisternum and metepimeron white pollinose; metepimeron with long, fine, apically crinkled, pale hair-like setae.

Legs. Coxae white pollinose. Prothoracic and mesothoracic coxae densely covered with long, slender, pale hair-like setae on anterior and lateral surfaces. Metathoracic coxa with similar hair-like setae anteroventrally and posterolaterally. All femora shining yellowish brown or reddish brown, often somewhat lighter below, usually slightly darker than tibiae and tarsi, with circlets of stout setae near apex; prothoracic femur lacking stout seta anteriorly on basal half; mesothoracic femur with 1-2 stout, pale setae anteriorly on basal half; metathoracic femur with anterior row of 4-5 pale bristles. Tibiae and tarsomeres mostly yellowish brown; apical tarsomeres and sometime metathoracic tibia brown distally. Prothoracic tibia with anterodorsal and posterodorsal row of short pale setae and posteroventral row of long, pale, hair-like setae; mesothoracic tibia with anterodorsal, anteroventral, and posteroventral rows of long pale setae and posterodorsal row of short, pale setae; metathoracic tibia with dorsal and anterior rows of short pale setae and ventral row of long, pale setae. Length of first tarsomere longer than or equal to length of second and third combined. All claws black with golden brown base. Prothoracic pulvilli brown; mesothoracic and metathoracic pulvilli yellow. 
Wing (FIG. 1E). 12.7-15.5 mm long (mean \pm S.D.: $13.9 \pm 1.1 ; \mathrm{N}=9$ ). Membrane usually hyaline apically; lightly infuscated in cells cup, and $\mathrm{a}_{1}$, most heavily infuscated in cells $\mathrm{c}$ and sc, br, bm, at base of cells $\mathrm{r}_{1}$ and $\mathrm{r}_{2+3}$, and around crossvein $\mathrm{r}-\mathrm{m}$. Halter with stem and knob brown or yellowish brown.

Abdomen. Tergites 1-6 shining black in ground color, with broad posterior white pollinose transverse band; each pollinose band mostly uniform in width. Tergite 1 with many long pale setae laterally. Tergites $2-6$ with shorter pale hair-like setae. Sternites 2-6 almost completely white pollinose, with some long, slender, apically crinkled, white hair-like setae, especially dense on sternites 5-6. Terminalia shining brown, with fans of long, sordid white hair-like setae; gonocoxite and gonostylus as in FIG. 2C.

Female. Similar to male.

Body length: $15.3-21.1 \mathrm{~mm}$ (mean \pm S.D.: $19.6 \pm 1.6 ; \mathrm{N}=11$ ).

Head. Width 1.5-1.6 times eye height. Frons mostly pale yellow pollinose, shining dark brown at midline only. Antenna $6.1 \mathrm{~mm}$ long; .antennomere:scape ratios: 1.0:0.8:3.4:0.6:3.3.

Thorax. Scutellum with marginal hair-like setae shorter than length of scutellum.

Wing (FIG. 1F). 13.7-17.4 mm long (mean \pm S.D.: $16.1 \pm 1.0 ; \mathrm{N}=11$ ). Membrane more extensively infuscated than in male; lightly infuscated apically and posteriorly, most darkly infuscated in cells c, sc, br, bm, bases of $r_{1}$ and $r_{2+3}$, and around crossvein r-m.

Legs. Femora usually uniformly yellowish brown to reddish brown, rarely with dorsal side darker. All tibiae, tarsi, and pulvilli yellow.

Abdomen. Tergites 1-6 shining dark brown to black in ground color; tergites 7-8 shining reddish brown in ground color. Tergites 1-7 with posterior pale yellow pollinose transverse band. Sternite 2 completely pale yellow pollinose; sternites 3-7 shining brown or black in ground color with broad posterior pale yellow pollinose band.

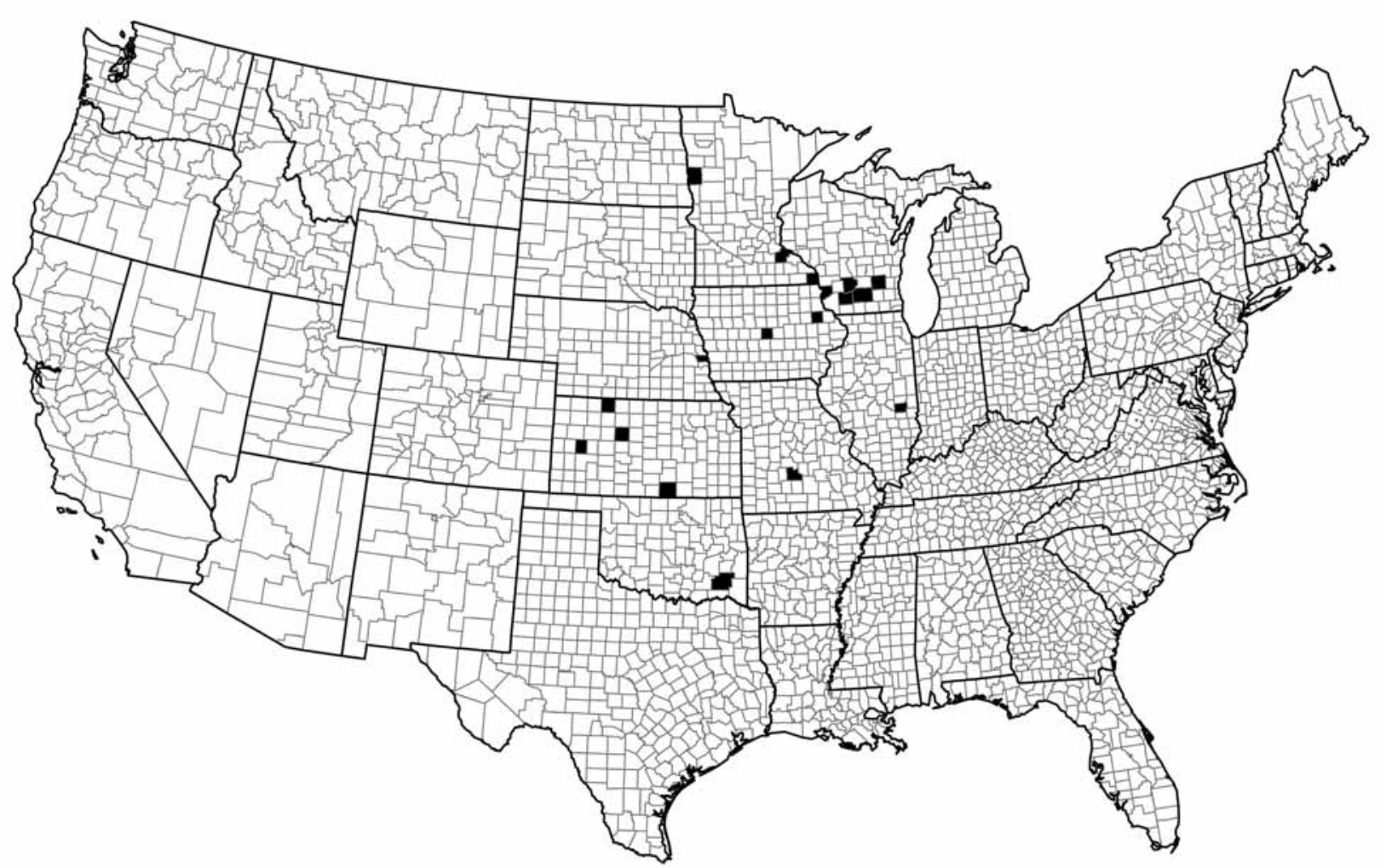

FIGURE 5. Distribution of Ceraturgus cruciatus by county. 
Distribution (FIG. 5). Midwest; Illinois to Kansas, and Minnesota to Oklahoma.

Discussion. Unfortunately, the type specimen, like so many of Say's types, apparently has not survived. The Diptera in Say's collection were entirely ruined soon after his death in 1834 (Weiss \& Ziegler 1931). Say (1823) described a rather large robber fly, nine-tenths of an inch long, or $22.9 \mathrm{~mm}$, with a yellow face; black thorax broadly margined with yellow; ferruginous wings; and black abdomen with wide, yellow, posterior annulations. Unfortunately, he did not mention the structure of the antennae. The only Ceraturgus species collected in Arkansas since 1823 are C. cornutus and C. elizabethae. C. elizabethae do not have abdomens with wide, yellow, posterior annulations. Since the publication of the description of $C$. cruciatus, this species has been recognized as one of the larger species in the genus with a long third flagellomere, thus eliminating $C$. cornutus, with its short third flagellomere, as a possibility. Although $C$. cruciatus has not been found in Arkansas again, is has been collected near the northern border in Missouri and near the western border in Oklahoma. The very similar Ceraturgus fasciatus has been collected near the eastern border of the state, in Mississippi. In 1820, while on his return from Major Long's expedition to the Rocky Mountains, Say traveled across Arkansas from Fort Smith in the northwestern part of the state to Cape Girardeau in southeastern Missouri, then down the Mississippi River along the entire eastern border of Arkansas to New Orleans (Weiss \& Zeigler 1931). It is therefore impossible to say with certainty which species Say had before him. In the interest of stability, the traditional definition of $C$. cruciatus is adopted here, but $C$. fasciatus, the darker form with a more eastern distribution, is removed from synonymy with it.

Back (1909) illustrated the antenna and female lateral aspect, Hull (1962) published six illustrations of various structures, and Artigas and Papavero (1991b) illustrated the spemathecae. Each of these authors failed to state the provenance of the illustrated specimens. They could have been either Ceraturgus cruciatus or $C$. fasciatus.

Most specimens have been collected in June and July. One specimen that I have examined is pinned with its presumed prey, a pentatomid bug.

\section{Ceraturgus (Ceraturgus) fasciatus Walker}

(FIGS 1G, 1H, 2D, 6)

Ceraturgus fasciatus Walker, 1849: 367.

Type material (photographs examined): Holotype, male, UNITED STATES: "HOLOTYPE, Ceraturgus fasciatus Walker [handwritten], det. J.E. Chainey, 1983" (with attached round "Holotype" label with red margin); "presented by E. Doubleday, Not. Ent. Club." (handwritten label); "One of Walker's series so named. EAW." ("Ceraturgus fasciatus Walker" on back); "Type" (round label with green margin); "44.90" (handwritten, meaning $90^{\text {th }}$ lot of 1844; "N. York" on back"; round label); U.S.A. New York. R. Foster. Pres. by E. Doubleday. 44-90" (handwritten); "R Foster New York" (handwritten), BMNH.

Additional material examined. CANADA. ONTARIO. Ancaster, 10 July 1965, ㅇ, C. E. H. Martin, CNC; 22 July 1996, ㅇ, B. de Jonge, CNC; Normandale, 28 June 1939, o* , G. E. Shewell, CNC.

UNITED STATES. CONNECTICUT. Fairfield County: Ridgebury, 12 June 1938, 우 [pinned with meloid beetle], USNM. Stamford, 13 June 1925, ox , USNM; 16 June 1929, ox, CAS; 30 June 1929, ox , USNM; 22 June 1930, ㅇ [pinned with scarab beetle], USNM; 23 June 1935, $\propto^{\star}$, USNM; 1 July 1935, ㅇ, USNM; 17 July 1935, 우 USNM; 7 July 1929, 우 USNM. Stamford, Poundridge, 23 June 1935, 우 [pinned with scarab beetle], USNM; 23 June 1935, ㅇ [pinned with formicid], USNM; 1 July 1935, 9 [pinned with scarab beetle], USNM. Litchfield County: Colebrook, 1 August 1900, ㅇ, AMNH; Cornwall, 1 July 1923, Twin Lakes, July 1931, ox 2 우, USNM; West Cornwall, July 1941, ㅇ, USNM. New Haven County: Mount Carmel, 30 June 1936, 2 ㅇ, Sommerman, INHS; South Meriden, 10 April 1910, + , H. Johnson, ANSP; 1

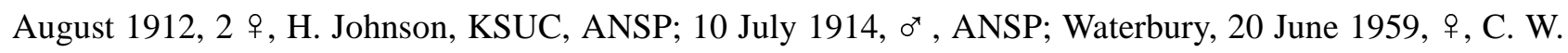


O'Brien, EMEC. New London County: Lyme, ox , C. T. Greene, USNM; 16 July 1915, ㅇ, A. B. Champlain, USNM; 13 June 1918, ㅇ, W. S. Fisher, USNM; 15 June 1918, $20^{\star}$, 오, A. B. Champlain, USNM; 16 June 1918, $2 \sigma^{\star}$, W. S. Fisher, USNM; 18 June 1918, $\sigma^{x}$ [pinned with scarab beetle], W. S. Fisher, USNM; 25 June 1918, ㅇ, W. S. Fisher, USNM; 28 June 1918, ㅇ, W. S. Fisher, USNM; 29 June 1918, ㅇ, W. S. Fisher, USNM; 30 June 1918, ㅇ, C.T. Greene, USNM; 3 July 1918, ㅇ [pinned with scarab beetle], C. T. Greene, USNM; 10 July 1918, ㅇ [pinned with elaterid beetle], USNM; 15 July 1918, ㅇ, A. B. Champlain, USNM.

DELAWARE. New Castle County: Newark, White Clay Creek, 15 July 2003, ㅇ, UDCC.

DISTRICT OF COLUMBIA. Washington, o* , MCZ; 22 June, ox, Townsend, USNM; 16 June 1899, 우, OSU; 25 June 1944, ㅇ, USNM.

MAINE. Franklin County: Dryden, 4 August 1970, , G. H. Heinrich, FSCA. York County: Biddeford, July 1908, 우, BMNH.

MARYLAND. Ann Arundel County: Camp Meade, ox, R. C. Shannon, USNM. Baltimore County: Soldiers Delight Natural Environment Area, 26 June 1981, $\circ$, C. S. Bergson, ANSP. Frederick County: Old Minx Campground, 16-18 July 1971, ㅇ, W. H. Tyson, USNM. Harford County: Fallston, 5 July 1964, ㅇ, L. L. Deitz, NCSU. Montgomery County: Cabin John, 27 June 1923, ㅇ, USNM; Great Falls, 26 June, o , G. M. Green, USNM; 2 July 1919, ox , ㅇ, W. L. McAtee, USNM; Plummers Island, 29 June 1913, ㅇ, R. C. Shannon, USNM. Prince George's County: 16 July, ox , , F. R. Cole, USNM; 3 July 1960, ㅇ, J. P. McCoy, MEM; Beltsville, 13 July 1912, ㅇ, W. L. McAtee, USNM; College Park, 29 June 1913, 우, F. Knab, USNM; on Rhus, 2 July 1931, ㅇ, L. P. Ditman, USNM; 5 July 1931, ㅇ, L. P. Ditman, USNM; 7 July 1931, ㅇ, USNM; 12 July 1931, ox , ㅇ, L. P. Ditman, LSAM; 23 July 1932, ㅇ, L. P. Ditman, USNM.

MASSACHUSETTS. Essex County: Manchester, 20 July 1924, ㅇ, MCZ.

Franklin County: Mount Toby, 8 August 1926, , K. A. Salman, CNC. Hampden County: Wales, 5 July 1937, ㅇ, O. E. Sette, CAS. Hampshire County: Amherst, 18 July 1905, ơ , USNM; 26 July 1956, ơ , R. Lavigne, ESUW; 13 June 1963, 우, A. Lavallee, UGCA; 1 July 1963, ox, A. G. Lavallee, WFBM; Amherst, Notch South, 5 August 1905, o* , USNM; Cummington, $1200 \mathrm{ft}$., ovipositing in soft earth, 10 July 1933, ㅇ, A. B. Gurney, USNM; Cummington, $1400 \mathrm{ft}$., emerging from soil in garden, 23 June 1933, ㅇ. A. B. Gurney, USNM; Mount Tom, ㅇ, G. Dimmock, USNM; Mount Tom, 24 June 1896, ㅇ, CNC; Southampton, 10 July 1894, $o^{x}$, ANSP; Ware, 23 June 1968, 5 o $^{x}$, A. Lavallee, UGCA; Ware, 24 July 1971, $o^{x}$ [pinned with scarab

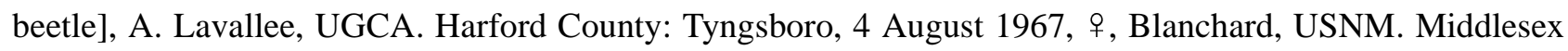
County: Framingham, 20 July 1969, 우 T. Lavallee, UGCA; 19 July 1970, 오, A. Lavallee, UGCA; Holliston, 3 August, ㅇ, MCZ; 8 August, ㅇ, N. Banks, MCZ; Sherborn, ㅇ, MCZ; 23 July 1922, ơ , CNC; Stoneham, 24 July 1921, $\odot$ [pinned with $o^{x}$ formicid], C. V. Blackburn, KSUC. Norfolk County: Blue Hills Reservation, $\sigma^{x}$, MCZ; Dover, ㅇ, MCZ; Ellis, 25 July 1915, ㅇ, MCZ; Needham, 18 August 1907, ㅇ, A. P. Morse, MCZ; Westwood, 9 July 1910, ㅇ, MCZ. Plymouth County: Humarock, 2 July 1935, o* , Darlington, MCZ. Worcester County: Northboro[ugh], 2 July 1936, o , C. A. Frost, CUIC; Princeton, Mt. Wachusett, 1500-2000 ft., 1 July 1918, 우, T. M. Forbes, CUIC; Southbridge, 20 July 1912, 우, USNM; Webster, 15 July 1928, o , USNM; 15 July 1928, o [pinned with formicid], USNM.

MICHIGAN. Iosco County: State Game Refuge, 24 July 1935, ㅇ, A. L. Olson \& L. K. Gloyd, UMMZ.

MISSISSIPPI. Oktibbeha County: Mississippi State, 22 April 1980, ox, Polk, MEM. Panola County: Sardis Lake, June 1960, ox , F. M. Hull, CNC. Webster County: 2 mi. S of Cumberland, 6 June 1971, ox , C. Bryson, MEM.

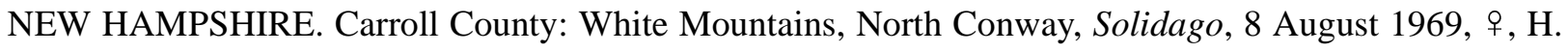

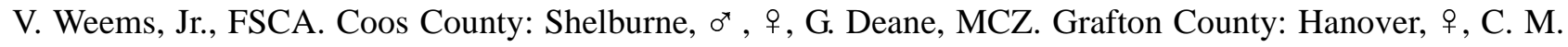

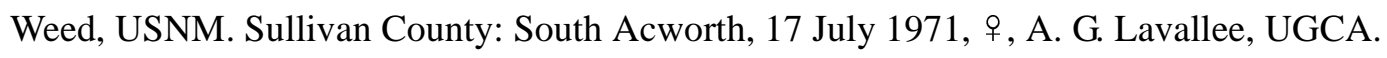

NEW JERSEY. Bergen County: Alpine, 10 June 1918, o*, MCZ; July 1937, ㅇ, USNM; Bear Swamp, near Ramsey, 10 July 1910, ㅇ, AMNH; Dumont, 14 July 1929, ㅇ, USNM; Englewood Cliffs, 12 July 1930, + , CAS; 8 July 1933, ㅇ, USNM; Fort Lee, 18 June 1922, ㅇ, USNM; Palisades, 3 July 1918, ㅇ, CSUC; Ramsey, 
2 August 1934, ox, W. Gertsch, FSCA; 2 July 1934, ㅇ, W. Gertsch, AMNH; 13 July 1934, 오, EMUS; 20 July 1934, ơ , EMUS; 21 June 1935, 우, AMNH; 15 July 1935, o ${ }^{\star}$, USNM. Cape May County: Cape May Point, 8 July 1917, 우, ANSP. Essex County: Forest Hill, June, 우, AMNH; Hemlock Falls, June, ox , AMNH. Mercer County: Trenton, 11 July, 우, ANSP. Middlesex County: July 1912, $0^{x}$, MCZ. Passaic County: Greenwood Lake, 20 July 1937, ox , USNM. Sussex County: Newton, 우, AMNH; Ogdensburg, 5 July 1929, ㅇ, AMNH; Stockholm, 10 July, $o^{x}$, MCZ. Union County: Plainfield, $2 \sigma^{x}$, MCZ; 4 July, 2 ㅇ, AMNH; Summit, 12 July 1910, ox, MCZ.

NEW YORK. County unknown: Homewood, 5 June 1922, ㅇ, OSU; Pond Ridge, 19 June 1938, 2 ๙ $^{x}$, Bromley \& Blanton, CUIC. Albany County: Albany, 27 June 1906, ox , NYSM; Albany Pine Bush, 4242'57"N 7352'48"W, 19 July 1991, 우, T. McCabe, NYSM; Bethlehem, 22 June 1870, 우, J. A. Lintner, NYSM; Clarksville, 10 July 1956, ㅇ, J. A. Wilcox, NYSM; Partridge Run State Game Area, 4 mi. N of Rensselaerville, 19 July 1970, ㅇ, G. \& K. Eickwort, CUIC; West Albany, 28 June 1931, ox , N. K. Bigelow, NYSM; 2 July 1931, $o^{x}$, N. K. Bigelow, NYSM. Bronx County: Mosholu, ơ , MCZ; 2 July 1922, ox , F. E. Watson, AMNH; Westchester, ㅇ, MCZ. Chenango County: Oxford Township, Mud Pond, 4 August 1964, 우 [pinned with sphecid wasp], L. L. Pechuman, CUIC. Columbia County: Copake Falls, July 1938, ㅇ, CAS. Delaware County: Mud Lake, 21/4 mi. SE of Davenport, 7 August 1963, 우 Pechuman, CSCA; East Meredith, 7 August 1963, o Pechuman, CSCA. Madison County: Georgetown, 16 July 1976, o , M. H. Evans, CUIC. Nassau County: Long Island, Oyster Bay, 13 May 1913, ox , AMNH. Niagara County: Rapids, 6 July 1934, 9 , CUIC. Orange County: Fort Montgomery, 19 July 1914, ㅇ, F. M. Schott, USNM; 16 July 1921, ㅇ, F. M. Schott, USNM; Tuxedo, 30 July 1928, + , AMNH; Tuxedo, Station for the Study of Insects, 28 July 1928, $\odot$, USNM. Putnam County: Patterson, 14 June 1935, $0^{x}$, + , FSCA; 10 June 1936, $\sigma^{*}$, SEMC; Peach Lake, 12 June 1937, $q$ [pinned with meloid beetle], USNM; 17 July 1937, $ᄋ$, USNM; Putnam Valley, 16 June 1941, 우, R. M. Schuster, CUIC; 17 June 1941, $\sigma^{x}$, R. M. Schuster, CUIC. Queens County: Long Island, Flushing, $\odot$, CAS; North Beach, Long Island, 27 July 1917, ox , F. M. Schott, MCZ. Rockland County: Bear Mountain, 1 August 1948, ㅇ, EMEC. Schuyler County: Texas Hollow, 1 July 1981, ox , L. L. Pechuman, CUIC. Suffolk County: Long Island, Napeague, 8 May 1946, ㅇ, R. Latham, CUIC. Tioga County: ex Erigeron sp., 6 July 1961, ơ , G. Brayshaw, CUIC; North Spencer, 2 August 1971, ㅇ [pinned with cercopid], L. L. Pechuman, CUIC. Tompkins County: Erigeron strigosus, 5 July 1961, G. Grayshaw, CSCA; Ithaca, July, o* , USNM; 22 June 1915, o*, CAS; 5 July 1916, ox , E. G. Anderson, USNM; 24 July 1917, ox , E. C. VanDyke, EMEC; 12 July 1926, 우, USNM; 10 July 1940, ㅇ, J. N. Belkin, OSU; 5 July 1947, ơ , C. Robinson, CNC; 1 July 1960, 우, H. E. Evans, CSCA; 4 July 1961, ㅇ, L. D. Uhler, CUIC; McLean, 19 July 1916, ㅇ, UMRM; 31 July 1917, son, USNM; 14 July 1926, ox , ㅇ, J. D. Hood, NYSM; 23 June 1940, ox , J. N. Belkin, OSU; 5 July 1940, ox, J. N. Belkin, OSU; 6 July 1928, ox, Klots, CUIC; 27 July 1958, ㅇ, CSCA. Michigan Hollow, 29 June 1932, $0^{*}$, SEMC; Ringwood, 13 June 1922, ox , L. S. West, CUIC; Ringwood, R14 July 1917, +, CUIC; 26 June 1922, ㅇ, CUIC; 25 July 1928, ox , TAMU; Six Mile, 22 June 1958, ox, D. F. Beneway, SEMC. Ulster County: Accord, July 1958, 우, F. Hough, USNM. Washington County: Salem, 5 July 1941, ㅇ, CSCA. Westchester County: Armonk, 18 June 1935, o* , H. Dietrich, FSCA; Hartsdale, 9 June 1941, ơ , G. P. Englehardt, CSCA; 1 August 1940, ㅇ, G. P. Englehardt, CAS; Katonah, June 1908, $20^{\star}$, 우, W. Beutenmuller, AMNH; Katonah, June 1908, $o^{x}$, W. Beutenmuller, FSCA; North Salem, 16 June 1940, $o^{x}$, USNM; 7 July 1940, 우, USNM; Pelman, 29 June 1926, 우, TAMU; Pocantico Hills, 22 June 1935, ơ , 우, C. W. Sabrosky, USNM; Rye, ex grass with Hydroecia sp, ex Apamea ryensis Bird, 15 June 1911, ox, AMNH; White Plains, 1 July 1923,

NORTH CAROLINA. Avery County: Pineola, 5 July 1936, ㅇ, D. L. Wray, NCSU; 9 July 1936, o* , D. L. Wray, NCSU. Buncombe County: Asheville, 1 July 1924, ox , USNM; Black Mountain, ox , AMNH; Swannanoa, 5 July 1917, ox , R. W. Leiby, NCSU; valley of Black Mts., 24-30 June 1906, ㅇ, W. Beutenmuller, AMNH. Burke County: Linville Falls, 6 June 1920, $o^{\star}$, F. Sherman, NCSU.

Macon County: Highlands, Blue Valley Lookout, 3500 ft., 29 June 1957, + , J. R. Vockeroth, CNC. Transylvania County: Cedar Mountain, 11-18 July 1954, ox , D. H. Janzen, EMEC; L. Toxaway, 8 July, ox , AMNH. 
Wake County: Raleigh, 15 June 1952, ㅇ [pinned with chrysomelid beetle], H. \& A. Howden, CNC. Yancey County: Mt. Mitchell Game Refuge, 18 August 1938, ${ }^{\star}$, NCSU.

OHIO: County unknown: Waterloo, 2 June 1899, ox, OSU. Ashland County: Loudonville, 10 June 1899, $3 o^{\star}$, MCZ; 14 June 1900, 2 o $^{x}, 4$ ㅇ, BMNH. Hocking County: Good Hope Township, 4 August 1940, ㅇ, E. S. Thomas, OSU. Knox County: Jackson Township, 14 June 1937, ox , D. J. Borror \& D. W. Jenkins, OSU. Ross County: Rt. 50 at Scioto River, 4 July 1989, 우, R. A. Androw, CMNH. Tuscarawas County: Oxford Township, 14 June 1937, ๙ $^{x}$, 우, D. J. Borror \& D. W. Jenkins, OSU. Vinton County: Brown Township, 11 July 1937, ㅇ, R. Goslin, OSU. Wayne County: East Union Township, 15 June 1937, 오, D. J. Borror \& D. W. Jenkins, OSU.

PENNSYLVANIA. County unknown: $\sigma^{\star}$, Heinz, CUIC; Halfway, 29 June 1964, $0^{x}$, S. W. Frost, PSUC; 2 July 1960, o ${ }^{\star}$, S. W. Frost, PSUC; Halfway Park, 19 June 1955, 오, PSUC; Penn-Roosevelt Dam, 14 June 1917, ơ , S. W. Frost, PSUC; Rockville, 5 July 1908, ㅇ, INHS; 5 July 1988, ox , W. F. Rapp, Jr., INHS; The Rock, 3 July 1946, ox , S. W. Frost, PSUC. Allegheny County: Buena Vista, 3 July 1936, ㅇ, R. H. McCauley, FSCA. Blair County: 30 June 1978, , CSUC; 14 July 1978, o , S. Bonta, BYU. Centre County: 4.3 km SSW of Marysville, State Game Lands 176, Scotia Barrens, scrub oak sand barrens, 370 m, 10 July 1996, ơ , C. W. Bier, CMNH; Bear meadows, 3 June 1944, ㅇ, S. W. Frost, PSUC; Boalsburg, 7 July 1931, 1957, ㅇ, S. W. Frost, PSUC; 24 June 1957, ㅇ, S. W. Frost, PSUC; Forest, 24 July 1931, ㅇ, A. Seeger, MCZ; Furgeson Township, 5 July 1969, ㅇ, D. L. Bierlein, CSCA; Oak Hall, 23 June 1943, ㅇ, V. R. Bater, PSUC; Rockview, 2 July 1931, , MCZ. Centre County: State College, 15 July 1928, ơ , C. B. Lewis, MCZ; June 1938, 우 [pinned with pentatomid bug], S. W. Frost, PSUC; 15 June 1944, 오, S. W. Frost, PSUC; 15 June 1944, $\sigma^{x}$, S. W. Frost, PSUC; 6 July 1946, ㅇ, L. J. Stannard, PSUC; 24 June 1955, ${ }^{x}$, JAC, PSUC. Chester County: Kennett Square, 30 July 1934, ox , C. H. Thomas, PSUC. Clearfield County: Forest, 28 July 1928, $o^{x}$, A. Seeger, MCZ; Shawville, o , J. Bauer, CMNH. Cumberland County: Carlisle Junction, 1 July 1909, ㅇ, W. R. Walton, USNM. Dauphin County: June 1915, ox , W. R. Walton, USNM; Harrisburg, 14 June, ㅇ, W. R. Waltonb, ANSP; 16 June, $\diamond^{\star}$, W. R. Walton, ANSP; 18 June, ㅇ, W. R. Walton, USNM; 23 June, 2 ㅇ, USNM; 25 June, $\sigma^{x}$, ANSP; 25 June, $\sigma^{x}$, W. R. Walton, ANSP; 26 June, + , W. R. Walton, ANSP; Heckton Mills, 8 July 1910, ㅇ, P. R. Myers, USNM; Hummelstown, 20 July, ㅇ, J. N. Knull, CNC; Inglenook, 22 June 1917, ox, W. S. Fisher, USNM; Linglestown, 16 July 1913, ㅇ, A. B. Champlain, USNM. Elk County: 4.7 km NE of Clarington along Millstone Creek, 4122'10"N, 7904'37"W, 24 July 1993, ox, W. Zanol \& M. Klingler, CMNH. Forest County: Kellettville, 28 June 1958, 우 J. Bauer, CMNH; Tionesta, 18 July 1924, ㅇ, Zahrobsky, CLEV; 19 July 1924, o $^{\star}$, Zahrobsky, CLEV. Lackawanna County: Scranton, 23 April 1911, 우, AMNH. Lehigh County: Lehigh Gap, 11 July 1897, 2 우 USNM. Philadelphia County: Manayunk, July, 우, P. Laurent, ANSP. Potter County: Ole Bull, streamside, 25 June 1955, o* WRH, PSUC. Tioga County: Marshlands, 10-13 July 1959, ㅇ, J. Bauer, CMNH. Union County: Buffalo Flat, between Buffalo and Branch Mt., 5 mi. W of Hartleton, $2600 \mathrm{ft}$., 30 July-1 August 1938, ㅇ, Rehn, Pate, \& Rehn, ANSP. Westmoreland County: 19 July 1958, ox, CSCA. York County: York, ox, M. C. Farley, BYU.

SOUTH CAROLINA. Pickens County: Clemson College, 19 June 1931, ox , F. Sherman, CUAC; Rocky Bottom, 21 June 1933, ㅇ, O. L. Cartwright, CUAC; 26 June 1934, ox, F. Sherman, CUAC; 31 July 1934, ㅇ, F. Sherman, CUAC.

TENNESSEE. Sevier County: Great Smoky Mountains National Park, Gatlinburg, 16 June 1942, ox , FMNH.

VERMONT. Orleans County: East Charleston, 2 August 1967, 우, AMNH. Rutland County: Sudbury, 23 June 1905, 4 ox , BMNH. Washington County: Warren Mt., 17 July 1952, ơ , CNC.

VIRGINIA. County unknown: Dixie Landing, 22 June, $\sigma^{\star}$, UAAM; Shenandoah National Historical Park, 24 June 1980, ox , D. Riley, TAMU. Arlington County: Glencarlyn, 11 June, ㅇ, MCZ; 16 June, ox , MCZ; 24 June, 오, MCZ; 13 July, ox , MCZ; 8 July 1915, 우, C. T. Greene, USNM; 17 June 1917, ㅇ, W. L. McAtee, USNM; Glencarlyn to mouth 4 mile Run, 17 June 1914, ox, W. L. McAtee, AMNH; Rosslyn, 11 July 1913, ㅇ, 
R. C. Shannonb, EMEC. Fairfax County: Chain Bridge, 23 June 1923, ox, J. M. Aldrich, USNM; 26 June 1923, ox , J. M. Aldrich, USNM; Dead Run, 20 June 1916, ox , R. C. Shannon, USNM; Falls Church, 27 June, ㅇ, CSUC; 5 July, ㅇ, CSUC; 6 July, ㅇ, MCZ; 8 July 1916, ox , ㅇ, J. N. Knull, USNM; Great Falls, 16 June, ㅇ, MCZ; 19 June, 2 o $^{\star}$, MCZ; 27 June, ơ , CSUC; 26 July 1914, ㅇ, USNM; 9 July 1920, ㅇ, USNM; Herndon, 22 July 1945, ㅇ, M. T. James, WSU; Vienna, 18 June 1936, ox, R. C. Shannon, USNM. Nelson County: 9 July 1917, o* , W. Robinson, USNM; 22 June 1926, 우, W. Robinson, USNM; 2-3 July 1927, 2 우, W. Robinson, USNM; 24 June 1928, ox , W. Robinson, USNM; 11 July 1928, 우, W. Robinson, USNM; 20 July 1928, ơ, 우, W. Robinson, USNM. Rockingham County: 4 mi. E of Timberville, 30 August 1980, ㅇ, J. M. Coffman, CSCA.

Male. Body length: 13.4-19.2 mm (mean \pm S.D.: $16.7 \pm 1.0, \mathrm{~N}=117)$.

Head. Width 1.5 times eye height. Face golden tomentose, with mystax of long bronze setae confined to lower third; upper face with shorter bronze setae almost reaching to antennal bases. Frons mostly shining brown; golden pollinose along inner eye margin; covered with short, thin, brown setae, except along midline. Vertex, including ocellar tubercle, shining dark brown, except for narrow golden brown pollinose band along inner compound eye margins. Postcranium dark brown in ground color, broadly pale yellow pollinose. Gena shining brown. Ocellar triangle tuberculate, with about 12-16 long pale setae. Postocular setae pale, many with proclinate apices. Postgena and stipes with dense vestiture of long, slender, apically crinkled, dark brown or black hair-like setae. Proboscis brown, laterally compressed, about 4.1 times as long as deep, deepest near base, tapered to rounded apex. Palpal segments about equal in length, dark brown, both with long, dark brown or black hair-like setae. Antenna 5.6-6.0 mm long; scape shining dark brown, with pale lateral setae along entire length; pedicel dull brown, with pale dorsolateral and ventrolateral setae at apex; flagellomeres dull black; antennomere:scape ratios 1.0:0.9:3.5:0.6:4.2.

Thorax. Cervical sclerites dark brown in ground color, thinly golden pollinose, with dense vestiture of long, slender, apically crinkled, dark brown or black hair-like setae. Pronotum sparsely golden brown pollinose, with dense pile of long, slender, apically crinkled, brown to pale setae covering antepronotum and with lateral patch of shorter, straighter, paler setae on postpronotum; postpronotal lobe thickly golden pollinose, covered with long, slender, erect pale setae. Propleuron densely golden pollinose, with dense vestiture of long, declinate, pale brown hair-like setae on proepisternum and reclinate pale hair-like setae on anterior portion of proepimeron. Prosternum sparsely golden pollinose, lacking setae. Scutum shining dark brown in ground color, with pale yellow pollinose. lateral band extending from postpronotal lobe to postalar lobe and across part of prescutellar edge of scutum, divided at prescutellar edge; with central dull, dark vitta extending from pronotum nearly to scutellum, divided by narrow brown vitta along midline, flanked anteriorly by pair of short narrow golden pollinose bands and pair of small golden pollinose patches at level of transverse suture; with pair of broad posterolateral dull black bare patches, divided by transverse suture, reaching from behind postpronotal lobes almost to scutellum; shining dull black areas of scutum mostly devoid of vestiture of short or long setae, except for patch of long hair-like setae between transverse suture and scutellum; pollinose and shining brown areas of scutum with vestiture of shorter, hair-like setae; lateral margin of scutum, in addition to several weaker setae, with 1-2 strong, pale presutural setae and 5-7 strong, pale postsutural, supra-alar setae. Postalar callus mostly pale yellow and brown pollinose; with short, pale hair-like setae laterally and long, strong, pale reclinate setae posteriorly. Scutellum black in ground color, yellow pollinose posteriorly on disc, devoid of strong, marginal setae, with several pale hair-like setae on disc and margin; some marginal setae equal in length to length of scutellum. Mediotergite shining dark brown; anatergite heavily pale yellow pollinose; katatergite sparsely brown pollinose, with fan of long, slender, apically crinkled, pale hair-like setae. Most mesopleural sclerites at least partly pale yellow pollinose, but pollen sparse or lacking on most of lower anepisternum, most of lower katepisternum, lower anepimeron, and meron, these areas appearing shining dark brown. Posterior half of anepisternum covered with long, fine, pale, apically crinkled hair-like setae; dorsal setae declinate, ventral setae reclinate. Anterior basalare brown; posterior basalare pale yellow polli- 
nose. Katepisternum with small dorsal patch of fine, pale hair-like setae. Anepimeron, katepimeron, and meron lacking setae. Basal swelling of pleural wing process pale yellow pollinose. Subalar sclerite brown. Metepisternum and metepimeron pale yellow pollinose; metepimeron with long, fine, apically crinkled, pale hair-like setae.

Legs. Prothoracic and mesothoracic coxae sparsely golden brown pollinose; densely covered with long, slender, pale hair-like setae on anterior and lateral surfaces. Metathoracic coxa densely pale pollinose; with similar setae anteroventrally and posterolaterally. All femora shining dark brown above, shining yellowish brown to reddish brown below, much darker than tibiae and tarsi, with circlets of stout setae near apex; prothoracic femur lacking stout seta anteriorly on basal half; mesothoracic femur with 1-2 stout, pale setae anteriorly on basal half; metathoracic femur with anterior row of 4-5 pale bristles. Tibiae and tarsomeres mostly yellowish brown; apical tarsomeres and sometimes metathoracic tibia brown distally. Prothoracic tibia with anterodorsal and posterodorsal row of short pale setae and posteroventral row of long, pale, stout setae; mesothoracic tibia with anterodorsal, anteroventral, and posteroventral rows of long pale setae and posterodorsal row of short, pale setae; metathoracic tibia with dorsal and anterior rows of short pale setae and ventral row of long, pale setae. Length of first tarsomere longer than or equal to length of second and third combined. All claws black with golden brown base. Prothoracic pulvilli brown; mesothoracic and metathoracic pulvilli yellow.

Wing (FIG. 1G). 11.2-15.3 mm long (mean \pm S.D.: $13.3 \pm 0.6 ; \mathrm{N}=117$ ). Membrane subhyaline or lightly infuscated apically; moderately infuscated in cells cup and $\mathrm{a}_{1}$; most heavily infuscated in cells $\mathrm{c}$ and sc, br, bm, at base of cells $r_{1}$ and $r_{2+3}$, and around crossvein r-m. Halter with stem and knob brown.

Abdomen. Tergites 1-6 shining black in ground color, with complete, broad, pale yellow, transverse, pollinose band; each pollinose band mostly uniform in width. Tergite 1 with many long pale setae laterally. Tergites 2-6 with shorter pale hair-like setae. Sternites 2-6 mostly brown; with elongate yellow pollinose patches in posterolateral corners sometimes nearly meeting at midline; with some long, slender, apically crinkled, brown hair-like setae, especially dense on sternites 5-6. Terminalia shining brown, with fans of long, golden brown hair-like setae; gonocoxite and gonostylus as in FIG. 2D.

Female. Similar to male.

Body length: $13.0-22.4 \mathrm{~mm}$ (mean \pm S.D.: $19.2 \pm 1.7 ; \mathrm{N}=109$ ).

Head. Width 1.5-1.6 times eye height. Antenna 6.0-6.3 mm long; antennomere:scape ratios: 1.0:0.9:3.4:0.6:3.9.

Thorax. Scutellum with marginal setae shorter than length of scutellum.

Wing (FIG. 1H). 10.7-17.8 mm long (mean \pm S.D.: $16.0 \pm 1.3 ; \mathrm{N}=109$ ). Membrane more extensively infuscated than in male; heavily infuscated throughout, lightest in cells cup and $\mathrm{a}_{1}$.

Legs. Femora usually uniformly yellowish brown to reddish brown, rarely with dorsal side darker. All tibiae, tarsi, and pulvilli yellow.

Abdomen. Tergites 1-6 shining dark brown to black in ground color; tergites 7-8 shining reddish brown in ground color. Tergites 1-7 with posterior pale yellow pollinose transverse band. Sternites $2-7$ brown or black in ground color, with complete or centrally broken broad posterior pale yellow pollinose band.

Distribution (FIG. 6). Southern Ontario, Maine and South Carolina west to Michigan and Mississippi.

Discussion. Mr. David Notton of the Entomology Department, BMNH, kindly examined the holotype and provided digital photographs. The northeastern $C$. fasciatus is readily distinguished from the more western $C$. cruciatus by the deep golden pollinose face and bronze mystax (white to pale yellow pollinose face and white to pale golden mystax in C. cruciatus); black or dark brown hair-like setae on postgena, stipes, and plapi (white in C. cruciatus); absent or poorly developed pale pollinose spots mesad to the postpronotal lobes (well developed in C. cruciatus); mostly polished black male abdominal sternites with narrow, medially divided, yellow pollinose bands along the posterior margin (mostly white pollinose sternites in male C. cruciatus). 


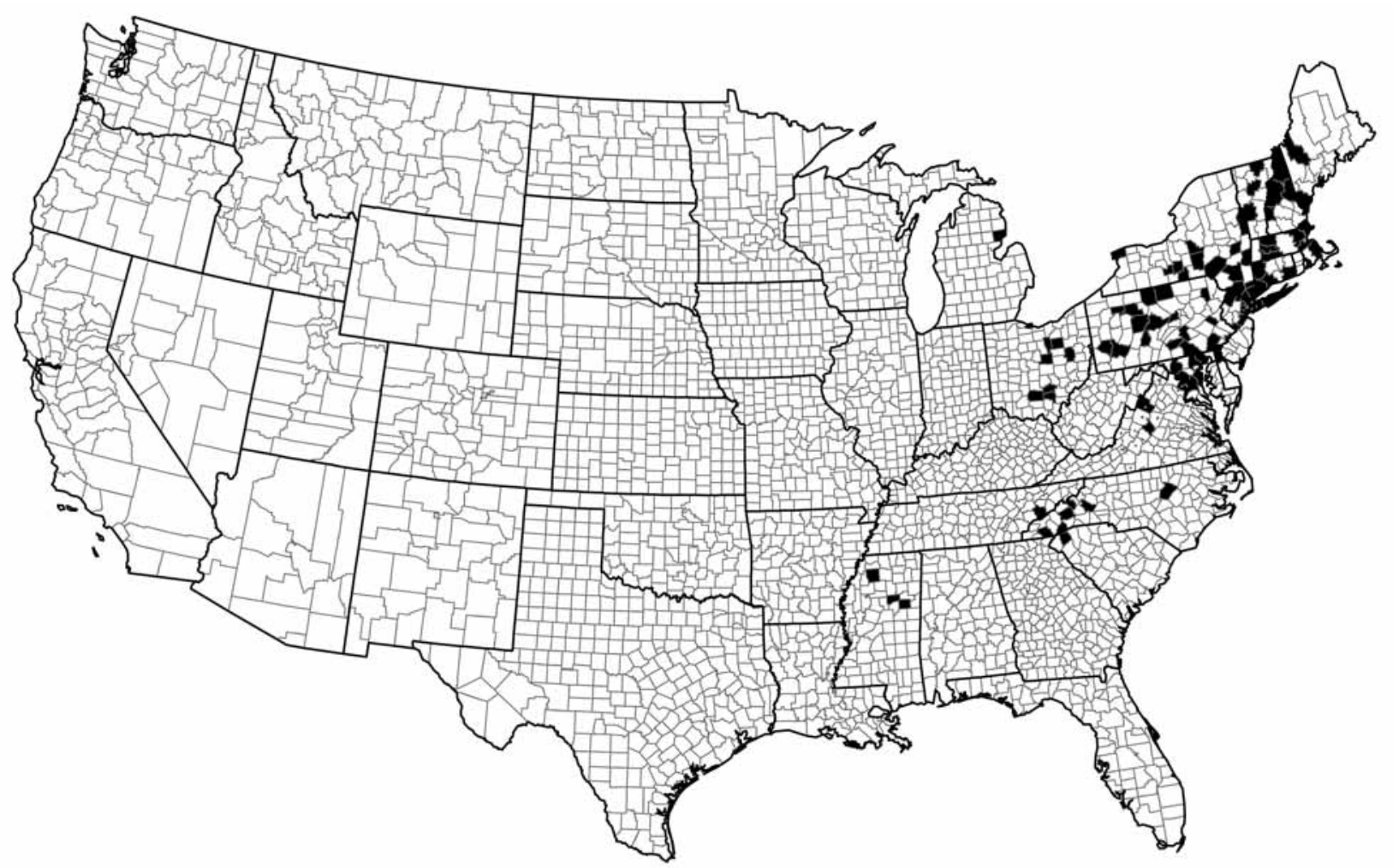

FIGURE 6. Distribution of Ceraturgus fasciatus by county.

Malloch (1917) described and illustrated larvae and pupae under the name C. cruciatus. They were collected in Maryland and therefore must be $C$. fasciatus rather than the more western $C$. cruciatus. Bromley (1946) listed C. fasciatus (as C. cruciatus) as a woodland species of Connecticut's oak and mixed mesophytic region. He reported finding it in brushy pastures or edges of fields or woods, frequently alighting among blackberry thickets or in wild indigo (Baptisia). "It flies rather heavily with a loud buzz. Its prey consists largely of small beetles [rose chafer, Macrodactylus subspinosus (Fabricius)] and other slow-flying insects. While feeding, this species suspends itself from a twig or leaf with a front foot, holding its prey with the others, in a manner similar to that of Diogmites."

Petch (1934) reported Ceraturgus cruciatus from Montreal at the time when C. fasciatus was considered a junior synonym.

Of 16 specimens that I have seen pinned with presumed prey, six are pinned with scarab beetles, four with other beetles (meloids, elarterid, chrysomelid), three with ants, one with a sphecid wasp, one with a cercopid, and one with a stink bug.

\section{Ceraturgus (Ceraturgus) aurulentus (Fabricius) (FIG. 7)}

Dasypogon aurulentus Fabricius, 1805: 166. Ceraturgus aurulentus: Macquart 1834: 289.

Type material examined. Holotype, sex unknown, UNITED STATES: "Type" (orange label), "D: aurulentus, ..New York [?Bohr]" (handwritten label), ZMUC.

Additional material examined. UNITED STATES. DELAWARE. "Del.”, + , ANSP.

GEORGIA. Union County: Blood Mountain, 17 September 1939, ㅇ, P. W. Fattig, USNM. 
MASSACHUSETTS. Norfolk County: Wellesley, 31 July 1966, ox , F. C. Thompson, CAS.

MICHIGAN. Washtenaw County: Ann Arbor, 17 August 1925, ㅇ, W. W. Newcomb, UMMZ.

NEW JERSEY. Camden County: Lucaston, near Lindenwold, 3 September 1987, 3 우, C. S. Bergson, ANSP. Gloucester County: Westville, 21 August 1892, ㅇ, C. W. Johnson, MCZ.

NEW YORK. Westchester County: Van Cortlandtville, + , USNM.

NORTH CAROLINA. Burke County: Table Rock, 7 August 1937, ㅇ, D. L. Wray, NCSU. Macon County: Highlands, 3865 feet, 11 August 1958, $20^{\star}$, J.G. Franclemont, CUIC, FSCA.

PENNSYLVANIA. Centre County, Ferguson Township, 22 August 1968, ㅇ, D. L. Bierlein, CSCA.

RHODE ISLAND. Washington County: Shannock, 27 August 1969, ㅇ, UGCA.

SOUTH CAROLINA. Oconee County: Cherry Hill Recreation Area, Route 107, 2000 ft., 7 September 1958, ㅇ, J. G. Franclemont, CUIC.

VIRGINIA. Fairfax County: near Plummers Island, Maryland, 18 September 1924, 우, A. Busck, USNM.

Female. Body length: 9.4-11.2 mm (mean \pm S.D.: $10.4 \pm 0.7$ ).

Head. Width 1.5 times eye height. Face golden tomentose. Frons, vertex except for ocellar tubercle, postcranium, and gena golden pollinose. Face with sparse mystax of golden setae confined to lower fifth; upper face with sparse, short golden setae reaching to antennal bases, these setae much shorter than scape. Frons laterally with few fine, short golden setae. Ocellar triangle tuberculate, black, with 8 golden setae. Postocular setae golden, stout. Postgena and stipes with dense vestiture of long, slender, apically crinkled, golden hairlike setae. Proboscis short, black, nearly cylindrical, more or less parallel-sided in lateral view, about 5 times as long as deep, not reaching far beyond level of face. Palpal segments about equal in length, black, both segments with long golden setae. Antenna 2.5-3.0 mm long; scape shining, with golden ventrolateral setae; pedicel and flagellomeres dull black; pedicel with golden lateral setae; antennomere:scape ratios 1.0:1.0:2.4:0.8:2.2.

Thorax. All sclerites black in ground color, mostly covered in dense golden pollen. Cervical sclerites densely golden pollinose, with dense vestiture of long, slender, apically crinkled, golden hair-like setae. Pronotum sparsely golden pollinose, with sparse pile of long, slender, golden setae covering antepronotum and lateral corners of postpronotum; postpronotal lobe with sparse golden pollen, covered with erect golden. Propleuron with dense vestiture of long, declinate, golden hair-like setae on proepisternum and reclinate hairlike setae on anterior portion of proepimeron. Prosternum golden pollinose except along midline, lacking setae. Scutum black in ground color, golden pollinose except for wide black vitta extending from pronotum nearly to scutellum and pair of broad posterolateral patches, each divided by narrow line of golden pollen along transverse suture, reaching from behind postpronotal lobes almost to scutellum; with sparse, short, reclinate golden hair-like setae throughout, including non-pollinose areas, and with prescutellar patch of longer, reclinate golden hair-like setae; setae of anterior portion of scutum shorter than scape. Lateral margin of scutum with 3 strong, golden, presutural bristles and 3 strong, golden, postsutural bristles in addition to smaller setae. Postalar callus with 3-4 golden bristles and many short hair-like setae. Scutellum golden pollinose along posterior margin, with short, sparse, golden hair-like setae on disc and 6-8 longer, weak, golden setae and several fine hair-like setae along margin. Mediotergite shining black. Anatergite and katatergite golden pollinose; katatergite with a fan of long, slender, apically crinkled, golden hair-like setae. Mesopleural sclerites mostly densely golden pollinose. Anepisternum and dorsal portion of katepisternum covered with fine, golden, apically crinkled hair-like setae. Anterior and posterior basalare densely golden pollinose. Anepimeron, katepimeron, and meron lacking setae. Basal swelling of pleural wing process densely golden pollinose. Subalar sclerite black. Metepisternum and metepimeron densely golden pollinose; metepimeron with long, fine, apically crinkled, golden hair-like setae.

Legs. Coxae densely golden pollinose; prothoracic and mesothoracic coxae densely covered with long, slender, golden hair-like setae on anterior and lateral surfaces; metathoracic coxa with similar hair-like setae anteroventrally and posterolaterally. Trochanters dark brown or black. Femora yellow on basal third to two- 
thirds, dark brown or black to apex, lacking circlet of stout setae near apex. Prothoracic femur covered with short, hair-like setae on most surfaces, the setae longer dorsally near base and ventrally on basal half or more. Mesothoracic and metathoracic femora similar to prothoracic tibia, but with 3-4 stronger, stout setae dorsally near apex. Tibiae yellow, with dark brown or black apices. Prothoracic tibia with posterodorsal row of short golden setae and anteroventral and posteroventral row of long golden setae; mesothoracic tibia with anterodorsal, anteroventral, and posteroventral rows of long golden setae, posterodorsal row with weaker setae; metathoracic tibia with dorsal, anterior and anteroventral rows of long golden setae. Tarsi mostly yellow, each tarsomere with dark apex; first tarsomere longer than second and third combined; all claws black with brown bases. All pulvilli yellow.

Wing. 7.7-9.1 mm long (mean \pm S.D.: $8.3 \pm 0.4$ ). Almost uniformly hyaline, lightly fumose in cells c and in cell sc near apex of vein Sc, at base of cells $r_{1}$ and $r_{2+3}$, and around crossvein $r-m$. Halter light yellowish brown. Cell cup open to wing margin.

Abdomen. Tergites 1-6 black, with broad golden pollinose bands at posterior margins; bands not extending forward at lateral margins; pollinose bands of tergites 2-6 V-notched in middle; tergites 1-2 with long, slender, apically crinkled, golden, lateral hair-like setae; remaining tergites with shorter lateral hair-like setae; tergites 6-7 black, shining. Sternites 1-6 predominantly golden pollinose; sternites 1-2 bearing sparse, long slender, apically crinkled, golden hair-like setae; sternites 3-6 bearing sparse, long, slender, predominantly straight, golden hair-like setae; sternites 6-7 dark brown to black, shining.

Male. Similar to female except as follows:

Body length: $9.4-10.0 \mathrm{~mm}$.

Head. Face above oral margin and long mystax bristles with golden hair-like about as long as scape. Antenna 2.6-2.8 mm long; antennomere:scape ratios 1.0:1.0:2.4:0.8:2.1.

Thorax. Hair-like setae of anterior portion of scutum about as long as scape; hair-like setae of prescutellar area of scutum dense and long.

Wing. 6.6-7.5 mm long.

Abdomen. Sternites 1-6 bearing dense, golden, hair-like setae.

Distribution (FIG. 7). Massachusetts to Georgia and Michigan.

Discussion. C. aurulentus is a distinctive species, readily recognized by its small size, rich golden pollen, bicolored femora and tibiae, and short, thin, parallel-sided proboscis.

Most of the holotype of $D$. aurulentus has been destroyed. All that remains is a scrap of the right side of the thorax measuring about $2 \mathrm{~mm}$ high by $1.2 \mathrm{~mm}$ wide. It includes a small portion of the scutum, extreme base of the wing, anterior and posterior basalares with an attached fragment of the anepisternum, and the basal swelling of the pleural wing process with an attached fragment of the anepimeron. The scutal fragment has a lateral, golden, pollinose stripe, about $0.6 \mathrm{~mm}$ wide, that bears several pale setae. The portion of mesonotum above the stripe is black. The other structures mentioned are heavily golden pollinose. The basalares together measure $0.4 \mathrm{~mm}$ high and $0.4 \mathrm{~mm}$ wide at the widest point. The specimens that I identify as $C$. aurulentus match this holotype. The only other species from the vicinity of New York with such small basalares is $D$. similis, and it does not have the heavy golden pollen found on the D. aurulentus holotype.

C. R. W. Wiedemann had access to the Fabricius collection (Stone 1980), and he probably worked with the type specimen when he redescribed and figured this species (Wiedemann 1828). No other specimens were known to exist until Dr. C. W. Johnson (1903) collected one in 1892. Wiedemann (1828) stated that the species measures 4 lines long, or $8.5 \mathrm{~mm}$.

In addition to the localities cited above, specimens have been reported from Connecticut (Stamford, 2 August 1936) (Bromley 1946, 1950b), Georgia (Blood Mountian, 17 September 1939) (Bromley 1950b), New York (New York City, Van Cortlandt Park) (Anonymous 1919), Ohio (Jackson County, Washington Township, male) (Bromley 1950b), and Pennsylvania (Delaware County, Castle Rock; Lehigh Gap, 11 July) (Johnson 1903). None of these specimens have been located in museums, despite extensive searches. 
C. aurulentus is a remarkably rare species. Apparently fewer than two dozen specimens have been collected in the past 200 years. Nonetheless, it is known to range from New England south to Georgia and west to Michigan. Specimens have been collected from late July to early September. Bromley (1946) found the Connecticut specimen, a teneral female, resting on a freshly cut black birch stump in a woodland clearing. He had visited the area regularly for many years, and searched intensively after finding this specimen, but he failed to find any others.

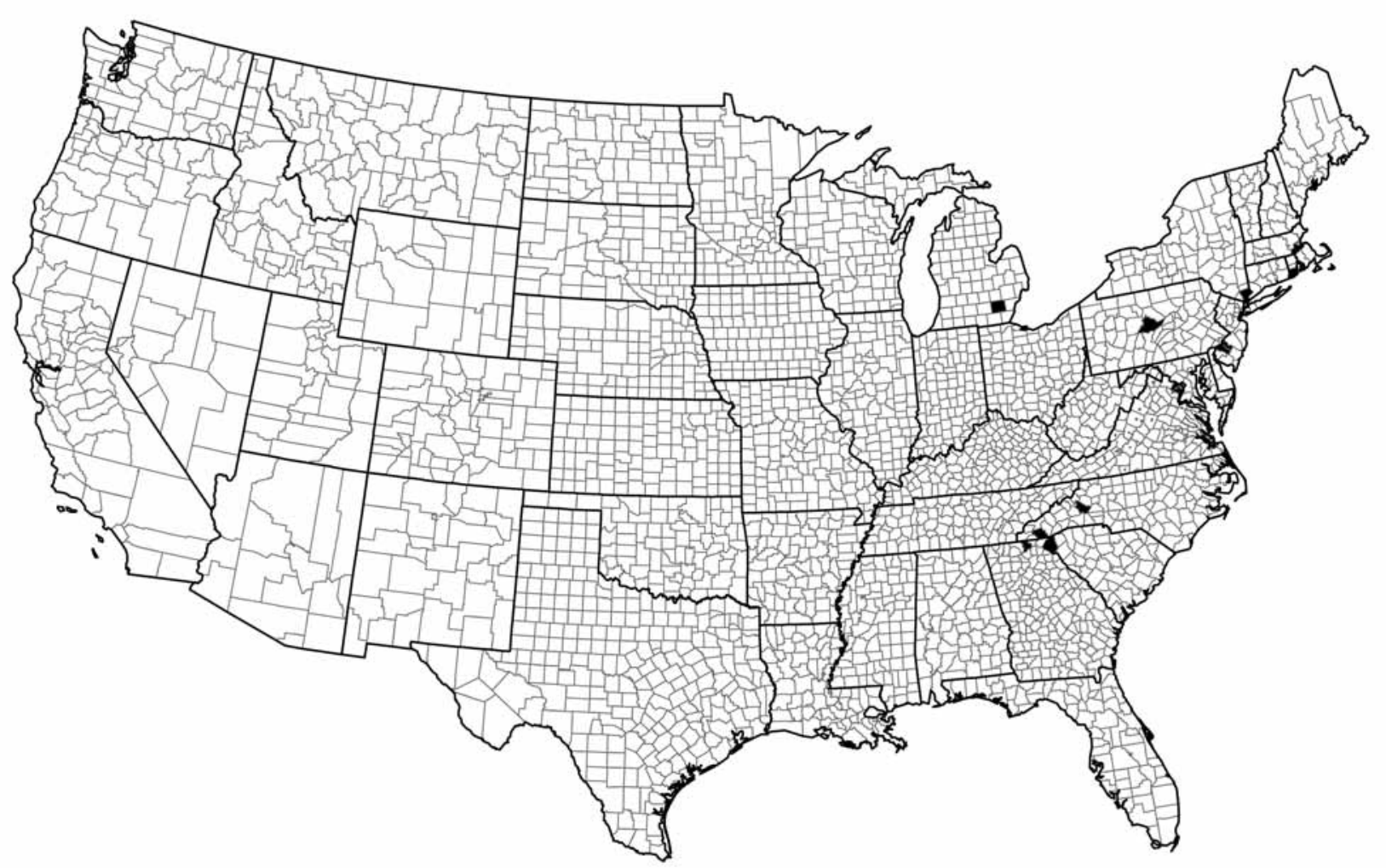

FIGURE 7. Distribution of Ceraturgus aurulentus by county.

Ceraturgus (Ceraturgus) similis Johnson

(FIG. 8)

Ceraturgus similis Johnson, 1912: 152.

Type material examined. Holotype, male, UNITED STATES: "2 mi. above Bashbish Falls, Mass., VI.27.12", “C. W. Johnson", "HOLOTYPE No. 624 (red label)", "M. C. Z. Type 27048” (red label), "Jan.July 2003 MCZ Image Database", MCZ. Bashbish Falls is located in Berkshire County, Massachusetts. Allotype, female, UNITED STATES: "Mt. Equinox, Vt, VI.5.10”, “C. W. Johnson”, “ALLOTYPE No. 625” (red label), "M. C. Z AlloType 27048 (red label)”, MCZ. Mt. Equinox is located in Bennington County, Vermont.

Additional material examined. UNITED STATES. MASSACHUSETTS. Middlesex County: Middlesex Falls, on granite ledge, 23 July 1939, Frost, ㅇ, USNM.

NEW YORK. Livingston County: Portage, 22 June 1916, W. T. Davis, $0^{x}$, USNM.

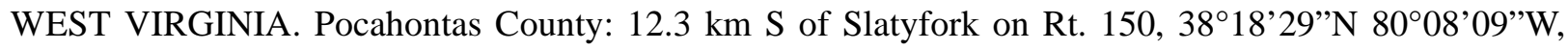
from blooms of Kalmia, 1 July 2001, R. Androw \& K. Karns, ㅇ, CMNH.

Male. Body length: 13.0-13.4 mm. 
Head. Width 1.6 times eye height. Face golden tomentose. Frons and vertex, including ocellar tubercle, shining black, except for narrow golden pollinose line above antennal bases and along inner compound eye margins. Postcranium and gena silvery to pale golden pollinose. Face with mystax of long golden setae confined to lower third; upper face with shorter golden setae almost reaching to antennal bases. Frons laterally with short, black setae. Ocellar triangle tuberculate, with about 18 long black setae. Postocular setae black, many with proclinate apices. Occiput and postgena with dense vestiture of long, slender, apically crinkled, black hair-like setae. Stipes with dense vestiture of long, slender, apically crinkled, golden hair-like setae. Proboscis black, laterally compressed, about 4.3 times as long as deep, deepest near base in lateral view, tapered to rounded apex. Palpal segments about equal in length, black, both with long, golden hair-like setae. Antenna $3.7 \mathrm{~mm}$ long, black, scape shining black, with black lateral setae along entire length; pedicel dull black, with black dorsolateral and ventrolateral setae at apex; flagellomeres dull black; antennomere:scape ratios 1.0:0.9:2.8:0.6:3.7.

Thorax. Cervical sclerites black, sparsely golden pollinose, with dense vestiture of long, slender apically crinkled, golden hair-like setae. Pronotum sparsely silvery pollinose, with sparse pile of long, slender, golden setae covering antepronotum and posterolateral corners of postpronotum; postpronotal lobe golden pollinose, covered with long, slender, erect golden hair-like setae. Propleuron with proepisternum silvery pollinose and proepimeron pale golden pollinose, with dense vestiture of long, declinate, golden hair-like setae on proepisternum and reclinate hair-like setae on anterior portion of proepimeron. Prosternum silvery pollinose, lacking setae. Scutum black or dark brown in ground color, silvery to golden pollinose, with bare central brown vitta extending from pronotum nearly to scutellum and pair of broad posterolateral bare patches, each divided by narrow line of pollen along transverse suture, reaching from behind postpronotal lobes almost to scutellum; lateral scutal pollen golden from postpronotal lobe to supra-alar area, otherwise pale golden or silvery; vestiture of short or long, erect or slightly reclinate setae restricted to pollinose areas surrounding vittae; anterior marginal and posterior marginal (prescutellar) setae pale, others black; postsutural setae longer than presutural setae; lateral margin of scutum, in addition to several weaker black setae, with 3 strong, pale presutural setae and 3 strong, pale postsutural, supra-alar setae. Postalar callus with short, pale hair-like setae laterally and long, strong, pale reclinate setae posteriorly. Scutellum shining black and bare at center of disc, otherwise sparsely silvery pollinose, with about 12 moderately strong, long, erect pale marginal setae, about as long as scutellum, and several marginal hair-like setae. Mediotergite shining brown, anatergite golden pollinose, katatergite silvery pollinose with fan of long, slender, apically crinkled, golden hair-like setae. Most mesopleural sclerites at least partly golden pollinose, but pollen sparse or lacking on lower anepisternum, lower katepisternum, lower and posterior anepimeron, and meron, these areas appearing shining or dull black. Posterior half of anepisternum covered with long, fine, golden, apically crinkled hair-like setae; dorsal setae declinate, ventral setae reclinate. Anterior basalare brown; posterior basalare silvery pollinose. Katepisternum with a few fine, golden hair-like setae posterodorsally. Anepimeron, katepimeron, and meron lacking setae. Basal swelling of pleural wing process golden pollinose. Subalar sclerite brown. Metepisternum and metepimeron golden pollinose; metepimeron with long, fine, apically crinkled, golden hair-like setae.

Legs. Coxae black in ground color; pale golden pollinose on anterior and lateral surfaces, black on posterior surface. Prothoracic and mesothoracic coxae densely covered with long, slender, golden, apically crinkled hair-like setae on anterior and lateral surfaces. Metathoracic coxa with similar setae anteroventrally and posterolaterally. All trochanters and femora shining black; femora covered with long golden hair-like setae, lacking long, stout setae. Tibiae shining golden brown, with dark brown apical ring; prothoracic tibia with anterodorsal and posterodorsal row of short golden setae and posteroventral row of long golden setae; mesothoracic tibia with anterodorsal, posterodorsal, anteroventral, and posteroventral rows of long golden setae; metathoracic tibia with dorsal, anterior and ventral rows of long golden setae. Tarsi shining golden brown, each tarsomere darker at apex; length of first tarsomere longer than or equal to length of second and third combined. All claws black with golden brown base. All pulvilli pale yellowish brown. 
Wing. 9.9-10.3 mm long; lightly to moderately infuscated; most lightly infuscated in, and posterior to, cells br, $\mathrm{d}$, and $\mathrm{m}_{2}$, more heavily infuscated apically and anteriorly; most heavily infuscated in apical portions of cells $\mathrm{c}$ and sc, at base of cells $\mathrm{r}_{1}$ and $\mathrm{r}_{2+3}$, and around crossvein r-m. Halter with stem and knob light brown.

Abdomen. Tergite 1 shining black in ground color; with posterior pale silvery pollinose band, narrow at midline, reaching to anterior margin laterally, with many long pale hair-like setae anterolaterally, many long pale setae posterolaterally. Tergites 2-6 shining black in ground color, with broad, posterior, golden pollinose, transverse band; bands not extending forward at lateral margin of tergite; each pollinose band with narrow anterior V-shaped notch at midline; tergite 2 with many long, slender, golden hair-like setae laterally; tergites 3-6 with shorter golden hair-like setae. Tergite 7 black. Sternites 1-7 black, covered with sparse, pale pollen and many long slender, golden, hair-like setae; setae especially heavy and dense on sternites 5-7. Terminalia black, with many long golden hair-like setae.

Female. Similar to male except as follows:

Body length: $11.3-13.5 \mathrm{~mm}$.

Head. Width 1.5 times eye height. Antenna $3.9 \mathrm{~mm}$ long; antennomere:scape ratios (allotype specimen) 1.0:0.9:3.1:0.6:3.6.

Wing. 10.8-11.7 mm long, nearly hyaline to lightly infuscated.

Legs. All pulvilli pale yellow.

Abdomen. Tergites 2-6 with posterior pollinose bands lacking narrow anterior V-shaped notch at midline. Tergites 7-8 black. Sternites 2-6 black, covered with heavy, pale, golden pollen and many long slender, golden hair-like setae; sternite 7 black; setae especially heavy and dense on sternites 6-7.

Distribution (FIG. 8). Vermont, Massachusetts, New York, and West Virginia.

Discussion. $C$. similis ranks among the rarest of robber flies. Only five specimens are known to exist, and they are all from the Northeast, collected early June to late July.

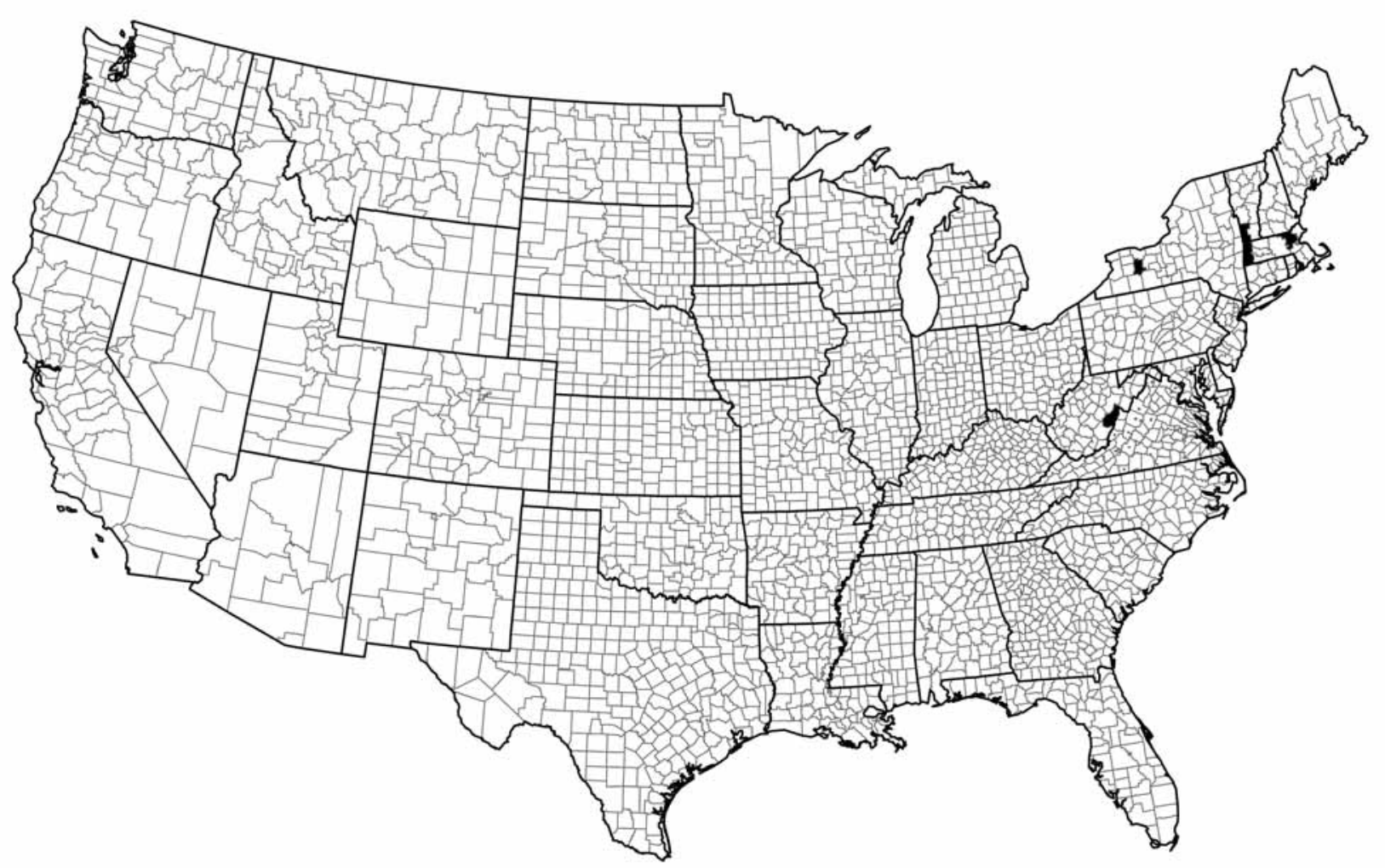

FIGURE 8. Distribution of Ceraturgus similis by county. 
Ceraturgus (Ceraturgus) nigripes Williston

(FIG. 9)

Ceraturgus nigripes Williston, 1886: 287.

Ceraturgus mabelae Brimley, 1924: 11. NEW SYNONYMY.

Type material examined. $C$. nigripes holotype, male, UNITED STATES, "det. by S. W. Williston", SEMC. C. mabelae holotype, female, UNITED STATES, “About 4000 ft., F. Sherman”, Linville Falls, NC, L May 1920", “Type No. 26832 U.S.N.M.” [red label], “TYPE Ceraturgus mabelae Brimley” [white label with double red outline], USNM.

Additional material examined. UNITED STATES. FLORIDA. County unknown: ㅇ, USNM.

GEORGIA. Habersham County: Tray Mountain, 13 May 1953, ㅇ, H. R. Dodge, WSU. Lumpkin County: Blood Mountain, 25 May 1940, ㅇ, P. W. Fattig, UGCA; 20 June 1951, 우 P. W. Fattig. Rabun County: Rabun Bald, 13 June 1933, ㅇ, O. L. Cartwright, CUAC; 6 June 1937, o* , P. W. Fattig, UGCA. Union County: Brasstown Bald, 5-8 June 1981, ㅇ, R. L. Penrose, CSCA. White County: Unicoi Gap, 17 May 1951, ox , ㅇ, P. W. Fattig, UGCA.

NORTH CAROLINA. County unknown: Great Smoky Mountains National Park, Andrews Bald, 16 June 1946, ㅇ, G. Steyskal, UMMZ; Great Smoky Mountians National Park, Forney Ridge, 6000 ft., 18 June 1940,

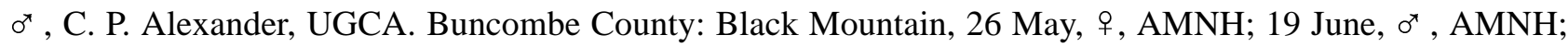
May 1910, 2 우, F. Sherman, NCSU, CUAC; 2 May 1979, ox , L. L. Pechuman, CUIC; Mount Graybeard, 23 May, 우, ANSP; $0^{x}$, FSCA; $20^{x}$, ㅇ MCZ. Burke County: Linville Falls, about 4000 ft., May 1920, 3 ox, NCSU; $o^{\star}$, USNM; 3 ㅇ, F. Sherman, NCSU; June 1920, ㅇ, USNM; Pisgah National Forest, holltop of Table Rock, ca. 4000 ft., 35 53.5'N 81 53.0'W, 27 May 1999, 2 o`, J. E. O'Hara, CNC; Table Rock Mountain, 4000 ft., 27 May 1999, 2 ox , J. M. Cumming, CNC. Cherokee County: Andrews, May 1908, ㅇ, F. Sherman, NCSU; $o^{*}$, ㅇ, F. Sherman, OSU. Haywood County: Cataloochee Divide, 5000 ft., 9-14 June 1940, 우 C. A. Frost, USNM; Nellie, June 1924, ㅇ, NCSU; Sunburst, May, 3 ox , C. S. Brimley, NCSU; Sunburst, 1 May 1913,

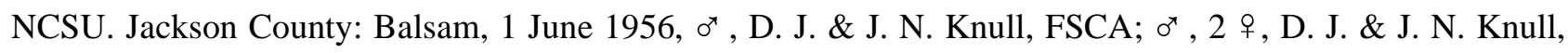
OSU. Macon County: May 1908, $o^{\star}$, F. Sherman, OSU; ㅇ, F. Sherman, NCSU; between Highlands and Franklin, 2200-4000 ft., May 1908, ㅇ, F. Sherman, NCSU; Highlands, 15 June 1936, o* , C. P. Alexander, USNM; Highlands, 15 June 1940, ㅇ, C. P. Alexander, UGCA; Highlands, 3-5000 ft., May 1936, 9 o $^{\star}, 5$ ㅇ, R. C. Shannon, USNM. Swain County: Andrews Bald, 24 July 1923, ㅇ, NCSU; Bryson City, 2-5000 ft., May 1936, $10^{x}$, 1 , R. C. Shannon, USNM; Bryson City, 2-5000 ft. [pinned with cerambycid], May 1936, ơ , R. C. Shannon, USNM; Bryson City, 3-5000 ft., May 1936, 2 ․ R. C. Shannon, USNM. Swain County: Great Smoky Mountains National Park, Clingman's Dome, $5500 \mathrm{ft} .$, o $^{\star}$, J. Bequaert, MCZ. Swain County: Great Smoky Mountains National Park, Cherokee, Newfound Gap, 4200 ft., 4 June 1962, ㅇ, J. R. Vockeroth, CNC. Wake County: Raleigh, 1 June 1956, ㅇ, D. J. \& J. N. Knull, CAS.

SOUTH CAROLINA. Oconee County: CCC Camp F2, 6 May 1938, ${ }^{x}$, 우, O. L. Cartwrigth, CUAC. Pickens County: Rocky Bottom, 15 May 1931, ㅇ, O. L. Cartwright, CUAC; 22 May 1934, + , O. L. Cartwright, CUAC.

TENNESSEE. Sevier County: Mount LeConte, 12 June 1937, 2 ๙ , O. L. Cartwright, USNM, CUAC.

Male. Body length: 9.6-14.0 mm (mean \pm S.D.: $12.8 \pm 1.2 ; \mathrm{N}=17$ ).

Head. Width 1.6 times eye height. Face golden tomentose. Frons and vertex, including ocellar tubercle, shining black, except for narrow golden pollinose line along inner compound eye margins. Postcranium and gena silvery to pale golden pollinose. Face with mystax of long golden setae confined to lower third; upper face with shorter golden setae almost reaching to antennal bases. Frons laterally with short, black setae. Ocellar triangle tuberculate, with about 15 long black and golden setae. Postocular setae black, many with proclinate apices. Postgena and with dense vestiture of long, slender, apically crinkled, black hair-like setae. Stipes with dense vestiture of long, slender, apically crinkled, golden hair-like setae. Proboscis black, laterally com- 
pressed, about 4.6 times as long as deep, deepest near base in lateral view, tapered to rounded apex. Palpal segments about equal in length, black, both with long, dark hair-like setae. Antenna $3.8 \mathrm{~mm}$ long, black; scape shining black, with black lateral setae along entire length; pedicel dull black, with black dorsolateral and ventrolateral setae at apex; flagellomeres dull black; antennomere:scape ratios 1.0:0.8:2.3:0.5:2.6.

Thorax. Cervical sclerites black, sparsely golden pollinose, with dense vestiture of long, slender apically crinkled, golden hair-like setae. Pronotum sparsely light golden pollinose, with sparse pile of long, slender, golden setae covering antepronotum and posterolateral corners of postpronotum; postpronotal lobe thickly deep golden pollinose, covered with long, slender, erect golden hair-like setae. Propleuron with proepisternum pale golden pollinose and proepimeron deep golden pollinose, with dense vestiture of long, declinate, golden hair-like setae on proepisternum and reclinate hair-like setae on anterior portion of proepimeron. Prosternum pale golden pollinose, lacking setae. Scutum black or dark brown in ground color, golden pollinose, with bare central brown vitta extending from pronotum nearly to scutellum and pair of broad posterolateral bare patches, each divided by narrow line of pollen along transverse suture, reaching from behind postpronotal lobes almost to scutellum; lateral scutal pollen golden from postpronotal lobe to supra-alar area, otherwise pale golden or silvery; vestiture of short or long, erect or slightly reclinate setae mostly restricted to pollinose areas surrounding bare vittae; anterior marginal and posterior marginal (prescutellar) setae pale, others black; postsutural setae longer than presutural setae; lateral margin of scutum, in addition to several weaker black setae, with 2-3 strong, pale presutural setae and 3-6 strong, pale postsutural, supra-alar setae. Postalar callus with short, pale hair-like setae laterally and long, strong, pale reclinate setae posteriorly. Scutellum shining black and bare at center of disc, otherwise sparsely silvery pollinose, with about 12 moderately strong, long, erect pale marginal setae, about as long as, or longer than, scutellum, and several marginal hair-like setae. Mediotergite shining brown, anatergite golden pollinose, katatergite silvery pollinose with fan of long, slender, apically crinkled, golden hair-like setae. Most mesopleural sclerites at least partly golden pollinose, but pollen sparse or lacking on lower anepisternum, lower katepisternum, lower and posterior anepimeron, and meron, these areas appearing shining or dull black. Posterior half of anepisternum covered with long, fine, golden, apically crinkled hair-like setae; dorsal setae declinate, ventral setae reclinate. Anterior basalare brown; posterior basalare pale golden pollinose. Katepisternum with a few fine, golden hair-like setae posterodorsally. Anepimeron, katepimeron, and meron lacking setae. Basal swelling of pleural wing process golden pollinose. Subalar sclerite brown. Metepisternum and metepimeron golden pollinose; metepimeron with long, fine, apically crinkled, golden hair-like setae.

Legs. All segments shining black or dark brown in ground color. Coxae pale golden pollinose on anterior and lateral surfaces, black on posterior surface. Prothoracic and mesothoracic coxae densely covered with long, slender, golden, apically crinkled hair-like setae on anterior and lateral surfaces. Metathoracic coxa with similar hair-like setae anteroventrally and posterolaterally. Femora covered with long, fine, golden hair-like setae, with circlet of stout setae near apex; mesothoracic and metathoracic femur with anterodorsal row of 35 long, stout setae. Prothoracic tibia with anterodorsal and posterodorsal row of short golden setae and posteroventral row of long golden setae; mesothoracic tibia with anterodorsal, posterodorsal, anteroventral, and posteroventral rows of long golden setae; metathoracic tibia with dorsal, anterior and ventral rows of long golden setae. Tarsi shining black or dark brown; length of first tarsomere longer than or equal to length of second and third combined. All claws black with golden brown base. All pulvilli pale yellowish brown.

Wing. 8.5-10.7 mm long (mean \pm S.D.: $9.6 \pm 0.8 ; \mathrm{N}=17$ ); lightly to moderately infuscated; most lightly infuscated in, and posterior to, cells br, $\mathrm{d}$, and $\mathrm{m}_{2}$; more heavily infuscated apically and anteriorly; most heavily infuscated in apical portions of cells $\mathrm{c}$ and $\mathrm{sc}$, at base of cells $\mathrm{r}_{1}$ and $\mathrm{r}_{2+3}$, and around crossvein $\mathrm{r}-\mathrm{m}$. Halter with stem and knob light brown or brownish yellow.

Abdomen. Tergite 1 shining black in ground color; with posterior pale silvery pollinose band, narrow at midline, reaching to anterior margin laterally, with many long pale hair-like setae anterolaterally, many long pale setae posterolaterally. Tergites $2-6$ shining black in ground color, with broad posterior golden pollinose 
transverse band; bands not extending forward at lateral edge of tergites; each pollinose band usually anteriorly notched at midline; tergite 2 with many long, slender, golden hair-like setae laterally; tergites 3-6 with shorter golden hair-like setae. Tergite 7 black. Sternites 1-7 black, covered with sparse, pale pollen and many long slender, golden, hair-like setae; setae especially heavy and dense on sternites 5-7. Terminalia black, with many long golden hair-like setae.

Female. Similar to male.

Body length: $11.7-15.9 \mathrm{~mm}$ (mean \pm S.D.: $13.3 \pm 1.1 ; \mathrm{N}=15)$.

Head. Width 1.6 times eye height. Antenna $3.7 \mathrm{~mm}$ long; antennomere:scape ratios: 1.0:0.8:2.9:0.4:2.4.

Wing. 9.6-14.4 mm long (mean \pm S.D.: $11.2 \pm 1.1 ; \mathrm{N}=15$ ); hyaline to lightly infuscated.

Legs. All pulvilli pale yellow.

Abdomen. Tergites 2-8 shining black in ground color. Tergites 2-6 with broad posterior golden pollinose transverse bands; bands often notched anteriorly at midline. Tergite 7 with narrow posterior golden pollinose transverse band. Tergite 8 black, lacking pollen. Sternites 2-6 black, covered with heavy, pale golden pollen and many long slender, golden hair-like setae; sternite 7 black; hair-like setae especially heavy and dense on sternites 6-7.

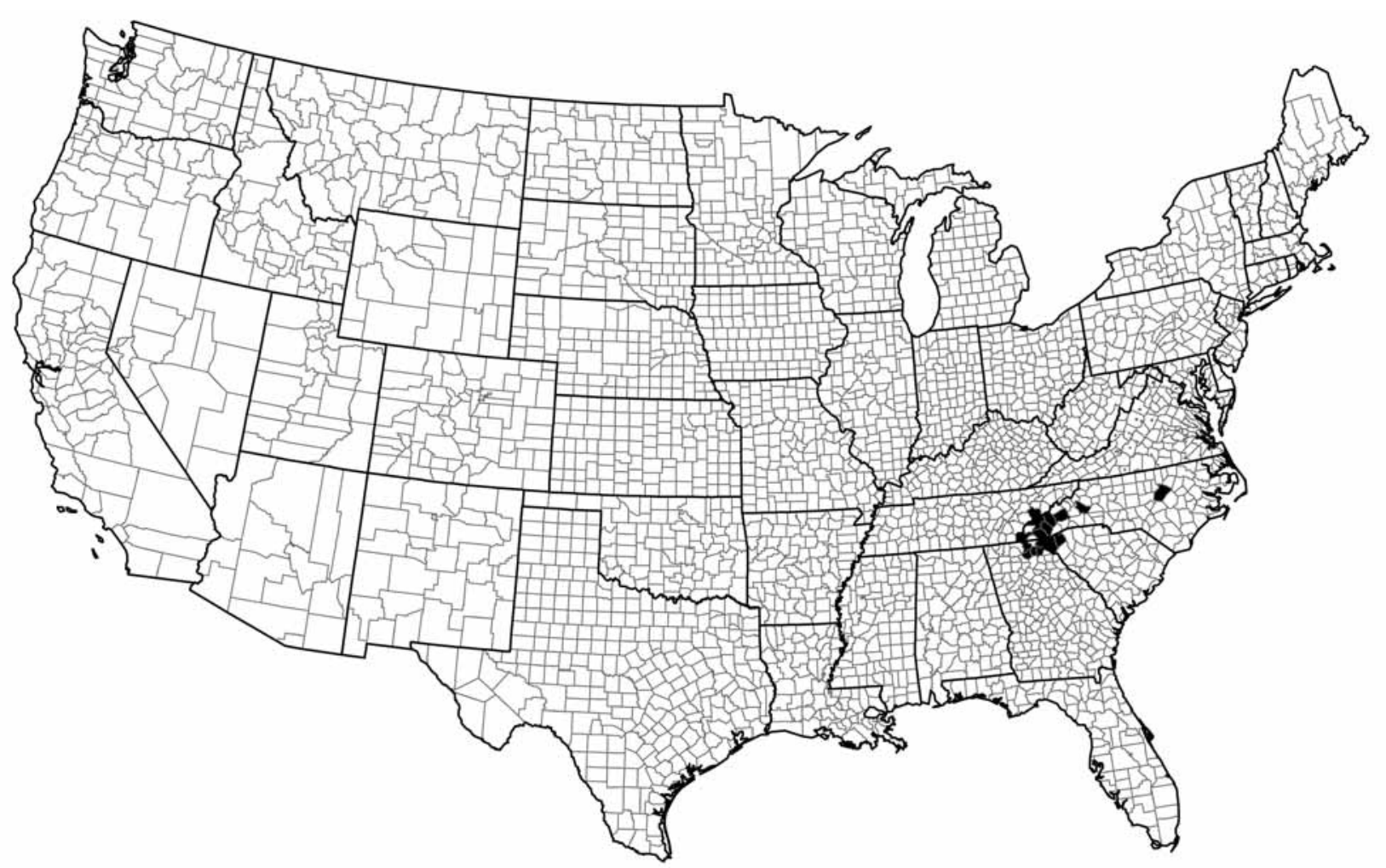

FIGURE 9. Distribution of Ceraturgus nigripes by county.

Distribution (FIG. 9). North Carolina, South Carolina, Georgia, and Tennessee. Johnson (1913) and Bromley (1950a) reported that there was a specimen of this species from Florida in the USNM. I did not find one in that collection, and I consider this an erroneous record. Fattig (1945) recorded one specimen collected at Neel Gap, Georgia, in May.

Discussion. Some specimens, such as those from Highlands, North Carolina, have hyaline wings, while others, such as those from Linville Falls, Bryson City, and Cataloochee Divide, North Carolina, have distinctly smoky wings.

Willison (1886) described $C$. nigripes from a single male specimen collected in Georgia, but he did not refer to that specimen as the type or the holotype. Back (1909) stated that the type was at the University of 
Kansas, but it is not listed in the Diptera type catalog for that collection (Byers et al. 1962). A single male specimen from the University of Kansas collection labeled simply "det. by S. W. Williston" is assumed to be the holotype and is now so labeled.

The holotype of $C$. mabelae appears to be merely a pale female specimen of $C$. nigripes. It is the only specimen ever to have been identified as $C$. mabelae, and it was collected at the same place and same time as many typical specimens of $C$. nigripes. As in typical specimens of $C$. nigripes, the femora and tibiae are uniformly dark. The antennomere:scape ratios are 1.0:0.8:2.7:0.5:2.4, similar to those reported here for $C$. nigripes, and the wings are hyaline.

One specimen that I examined is pinned with its presumed prey, a cerambycid beetle. Fattig (1945) reported Auplopus architectus (Say) (as Pseudagenia architecta (Say)) (Hymenoptera: Pompilidae) as prey of this species.

In most respects, $C$. nigripes appears to be nearly identical to $C$. similis, although it is easily distinguished from the latter by its completely black legs.

Most specimens have been collected from early May to late June.

\section{Subgenus Ceraturgopsis}

Ceraturgopsis Johnson, 1903: 111. Type species: Dasypogon cornutus Wiedemann, here fixed.

Johnson (1903) described the new genus Ceraturgopsis with D. cornutus as the type species, although the specimens before him at that time actually belonged to an undescribed new species. Martin (1965) described Ceraturgus johnsoni from Johnson's misidentified Florida specimens. He believed that “... Ceraturopsis being based on a name and not on a species, is not a valid genus," and he declared, "Ceraturgopsis is not only invalid but if it were valid, it would be a synonym of Ceraturgus." Subsequent authors have treated it as a synonym of Ceraturgus, even in the most recent catalog of robber fly genera (Geller-Grimm 2003). According to the International Code of Zoological Nomenclature, Article 70.3 (International Commission on Zoological Nomenclature 1999), "If an author discovers that a type species was misidentified ..., the author may select, and thereby fix as type species, the species that will, in his or her judgment, best serve stability and universality, either...the nominal species previously cited as type species...or the taxonomic species actually involved in the misidentification." Ceraturgopsis is here treated as a subgenus, and the type species is fixed as Ceraturgus cornutus (Wiedemann).

Back (1909) stated that the third flagellomere of Ceraturgopsis is "entirely naked." However, close examination of the third flagellomeres of all three species included in this subgenus reveals them to have dense, very short pubescence. This character, and the fact the third flagellomere is short, about as long as the scape, are sufficient to separate the species of this subgenus from those of subgenus Ceraturgus.

\section{Ceraturgus (Ceraturgopsis) oklahomensis (Bromley) \\ (FIGS 10A, 11)}

Ceraturgus oklahomensis Bromley, 1934: 225.

Type material examined. Holotype, male, UNITED STATES: “Caddo County, Okla., 16.IV.33, R. Dahms", "HOLOTYPE Ceraturgopsis oklahomensis Bromley" [red label, handwritten], "SW Bromley Collection 1955”, USNM. Allotopotype, female, UNITED STATES, “Caddo Co, Okl, April 16, 1933, R. Dahms”, “Allotopotype, Ceraturgopsis oklahomensis Bromley”, “A. E. Pritchard Collection, 1962” (red label, handwritten), USNM. Paratype, female, UNITED STATES, “Norman, Okla., 9.IV.1932, R. D. Bird”, PARATYPE, Ceratur- 
gopsis oklahomensis Bromley" [red label, handwritten], SW Bromley Collection 1955", "Ceratrugopsis oklahomensis Bromley Det. S. W. Bromley 1934", USNM.

Additional material examined. UNITED STATES. OKLAHOMA. Cleveland County: Norman, 11 April 1932, ox , R. D. Bird, USNM. Grady County: Verden, 22 April 1934, ơ , R. Dahms, CUIC. Payne County: 12 April 1925, ㅇ, W. J. Brown, USNM. Payne County: Ripley, 21 April 1934, ơ , 우, A. E. Pritchard, BMNH; 5

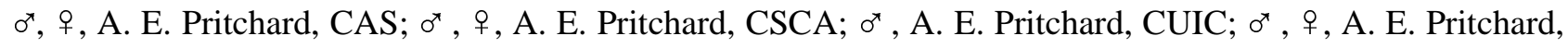
FSCA; $o^{x}$, A. E. Pritchard, JSUC; $0^{x}$, ㅇ, A. E. Pritchard, MCZ; $150^{x}, 7$ ㅇ, A. E. Pritchard, USNM; 2 ㅇ, A. E. Pritchard, OSEC; 6 June 1934, $\sigma^{x}$, A. E. Pritchard, USNM. Payne County: Stillwater, 29 April 1932, ㅇ, W. D. Davis, USNM; 21 April 1934, $2 \sigma^{\star}, 2$ ㅇ, A. E. Pritchard, AMNH. Woods County: 2 May 1936, sex unknown, R. Kaiser, OSEC. Woodward County: 9.6 km NE of Woodward, on Pyrropapus grandiflorus, 12 May 1984, 우, J. Wenzel, R. Brooks, C. Michener, \& D. Wahl, SEMC.

TEXAS. Blanco County: Pedernales Falls State Park, 16 April 1990, ox 2 우, A. Hook, BYU; 18 March 1994, ox , A. W. Hook, BYU. Montague County: Forestburg, 6 April 1941, $20^{x}$, April 1941, ㅇ, L. H. Bridwell, USNM; 14 April 1941, o , H. Bridwell, WSU; 14 April 1941, ㅇ, L. H. Bridwell, USNM; 15 April 1941, ㅇ, L. H. Bridwell, USNM; 18 April 1941, ơ , L. H. Bridwell, USNM; 24 March 1942, $o^{x}$, L. H. Bridwell, MCZ; 30 March 1942, 3 ox , L. H. Bridwell, USNM; 31 March 1942, 2 ox , L. H. Bridwell, AMNH; 31 March 1942, $20^{\star}$, L. H. Bridwell, WSU; 31 March 1942, 2 ox , L. H. Bridwell, MCZ; 31 March 1942, 6 o , 6 우 L. H. Bridwell, USNM. Potter County: Wildcat Bluff, NW edge of Amarillo, 18 April 1997, o , D. Sissom \& A. Roberts, WTAM. Travis County: Austin, 14 March 1986, ㅇ, J. Neff, BYU; 28 March 1993, ơ , A. W. Hook, BYU; 11 April 1993, + , A. W. Hook, BYU.

Male. Body length: 10.4-14.6 mm (mean \pm S.D.: $12.2 \pm 1.2 ; \mathrm{N}=18$ ).

Head. Width 1.6 times eye height. Face white tomentose. Frons, vertex, ocellar tubercle, postcranium, and gena white pollinose; ocellar tubercle, narrow midfrontal area immediately below ocellar tubercle, and gena only thinly pollinose. Face with mystax of long white setae confined to lower half; upper face with shorter white setae reaching to antennal bases. Frons laterally with short, thin, white setae. Ocellar triangle tuberculate, with about 10-14 long white setae. Postocular setae white, many with proclinate apices. Postgena and stipes with dense vestiture of long, slender, apically crinkled, white hair-like setae. Proboscis dark brown or black, laterally compressed, about 3.3 times as long as deep, deepest near base, tapering to rounded apex. Palpal segments about equal in length, dark brown, both with long, pale hair-like setae. Antenna $2.7 \mathrm{~mm}$ long, dark brown or black; scape shining, with pale lateral setae along entire length; pedicel dull, with pale dorsolateral and ventrolateral setae at apex; flagellomeres dull; first flagellomere with conspicuous dorsal row of many short, pale, proclinate setae on basal half; antennomere:scape ratios 1.0:1.0:3.2:0.4:1.0.

Thorax. Cervical sclerites dark brown, sparsely white pollinose, with dense vestiture of long, slender, apically crinkled, white hair-like setae. Pronotum sparsely light golden pollinose, with dense pile of long, slender, apically crinkled, white setae covering antepronotum and with lateral patch of shorter, straight, white setae on postpronotum; postpronotal lobe thickly white pollinose, covered with long, slender, erect white setae. Propleuron white pollinose, with dense vestiture of long, declinate, white hair-like setae on proepisternum and reclinate hair-like setae on anterior portion of proepimeron. Prosternum thinly white pollinose, lacking setae. Scutum dark brown in ground color, with continuous, broad, white pollinose, lateral and posterior band extending from postpronotal lobe to postalar lobe and across prescutellar edge of scutum; with central brown vitta extending from pronotum nearly to scutellum, divided by thin brown pollinose vitta along midline, flanked anteriorly by short pale golden pollinose bands; with pair of broad posterolateral shining brown patches, divided by narrow line of white pollen along transverse suture, lightly dusted with brown pollen, reaching from behind postpronotal lobes almost to scutellum; completely covered with vestiture of short or long, erect or slightly reclinate pale setae; postsutural setae longer than presutural setae; lateral margin of scutum, in addition to several weaker setae, with 6-10 strong, pale presutural setae and 8-10 strong, pale postsutural, supra-alar setae. Postalar callus with short, pale hair-like setae laterally and long, strong, pale reclinate 
setae posteriorly. Scutellum black in ground color, sparsely white pollinose on disc and margin, with about 14 moderately strong, long, erect pale marginal setae, about as long as, or longer than, scutellum, and several marginal hair-like setae. Mediotergite shining black; anatergite thickly white pollinose; katatergite silvery pollinose with fan of long, slender, apically crinkled, white hair-like setae. Most mesopleural sclerites at least partly golden pollinose, but pollen sparse or lacking on lower anepisternum, lower katepisternum, lower and posterior anepimeron, and meron, these areas appearing shining or dull black. Posterior half of anepisternum covered with long, fine, pale, apically crinkled hair-like setae; dorsal setae declinate, ventral setae reclinate. Anterior basalare brown; posterior basalare pale pollinose. Katepisternum, anepimeron, katepimeron, and meron lacking setae. Basal swelling of pleural wing process white pollinose. Subalar sclerite brown. Metepisternum and metepimeron white pollinose; metepimeron with long, fine, apically crinkled, pale hair-like setae.

Legs. All segments shining dark brown or black in ground color. Coxae lightly dusted with white pollen. Prothoracic and mesothoracic coxae densely covered with long, slender, white, apically crinkled hair-like setae on anterior and lateral surfaces. Metathoracic coxa with similar hair-like setae anteroventrally and posterolaterally. All femora with circlets of several stout, pale setae near apex; prothoracic femur with 1 stout, white seta anteriorly near middle; mesothoracic femur with 2 stout, white setae anteriorly near middle; metathoracic femur with anterior row of 5-8 white bristles. Prothoracic tibia with anterodorsal and posterodorsal row of short pale setae and posteroventral row of long pale setae; mesothoracic tibia with anterodorsal and posteroventral rows of long golden setae and posterodorsal row of short, white setae; metathoracic tibia with dorsal, anterior and ventral rows of long pale setae. Length of first tarsomere longer than or equal to length of second and third combined. All claws black with golden brown base. All pulvilli pale yellowish brown.
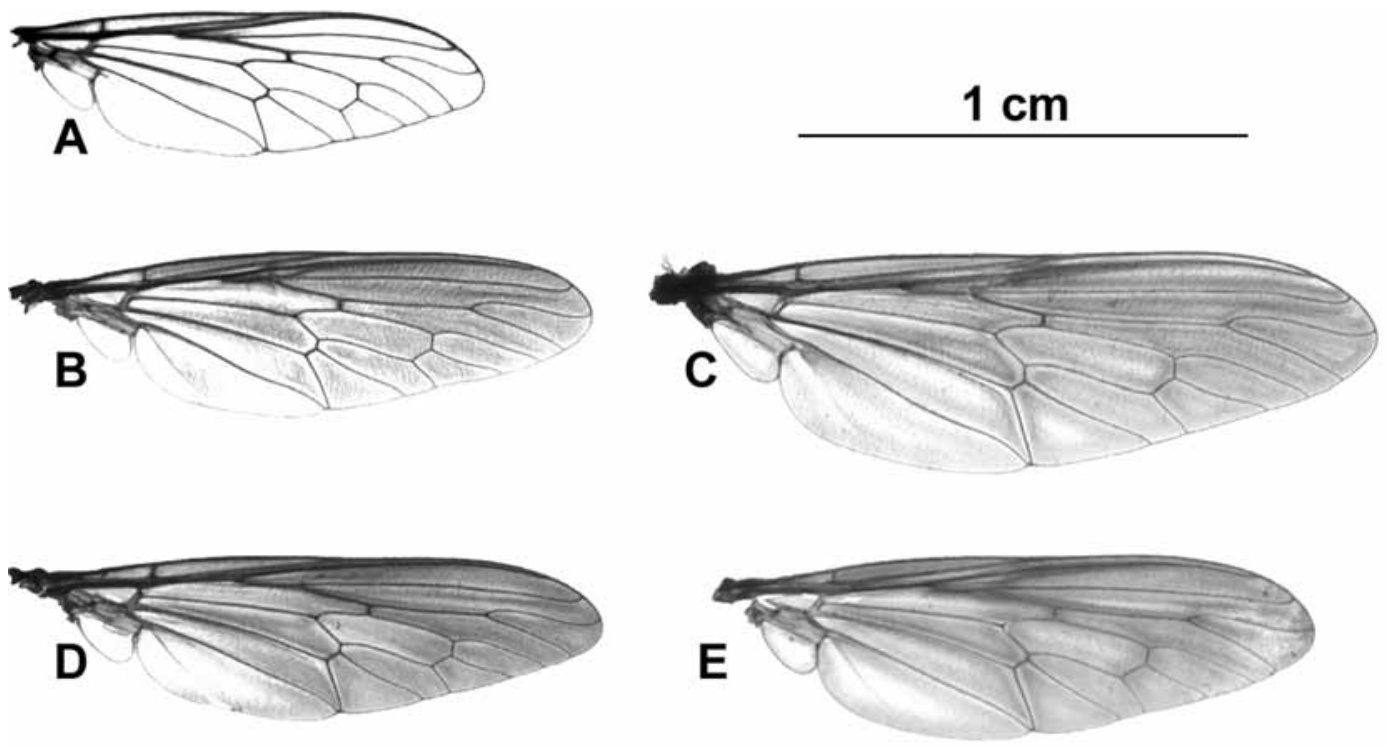

FIGURE 10. Ceraturgus, right wing, dorsal view: A, C. oklahomensis, male; B, C, C. cornutus, male and female, respectively; D, E, C. johnsoni, male and female, respectively.

Wing (FIG. 10A). 8.2-11.3 mm long (mean \pm S.D.: $9.4 \pm 0.9 ; \mathrm{N}=18$ ). Hyaline throughout, except for some light infuscation along some veins and crossveins. Halter with stem and knob brown or brownish yellow.

Abdomen. Tergite 1 shining black in ground color; with posterior white pollinose band, narrow at midline, reaching to anterior margin laterally, with many long pale hair-like setae anterolaterally, many long, stout, pale setae posterolaterally. Tergites 1-5 shining black in ground color, with broad posterior white pollinose transverse band; bands not extending forward at lateral margins of tergites 2-5; each pollinose band usually complete, but sometimes anteriorly notched or interrupted at midline by narrow patch of brown pollen. Tergite 
2 with many long, slender, pale hair-like setae laterally; tergites 3-6 with shorter, pale hair-like setae. Tergites 6-7 shining black. Sternites 1-7 shining black, with dusting of brown pollen and some long, slender, pale hairlike setae. Terminalia black, with many long pale hair-like setae.

Female. Similar to male.

Body length: $9.8-16.0 \mathrm{~mm}$ (mean \pm S.D.: $12.6 \pm 1.9 ; \mathrm{N}=12$ ). Similar to male wing.

Head. Width 1.6 times eye height. Antenna $3.7 \mathrm{~mm}$ long; antennomere:scape ratios: 1.0:1.1:3.3:0.3:0.9.

Wing. 8.2-11.4 mm long (mean \pm S.D.: $9.8 \pm 1.1 ; \mathrm{N}=12$ ).

Legs. All segments reddish brown to yellowish brown. All pulvilli pale yellow.

Abdomen. All tergites shining black or dark brown in ground color. Tergites 2-5 with broad posterior white pollinose transverse bands; bands often notched anteriorly at midline. Tergite 6-7 wholly shining black, lacking pollen. Sternites 1-8 shining black or dark brown, with light dusting of brown pollen and some long, slender, pale hair-like setae.

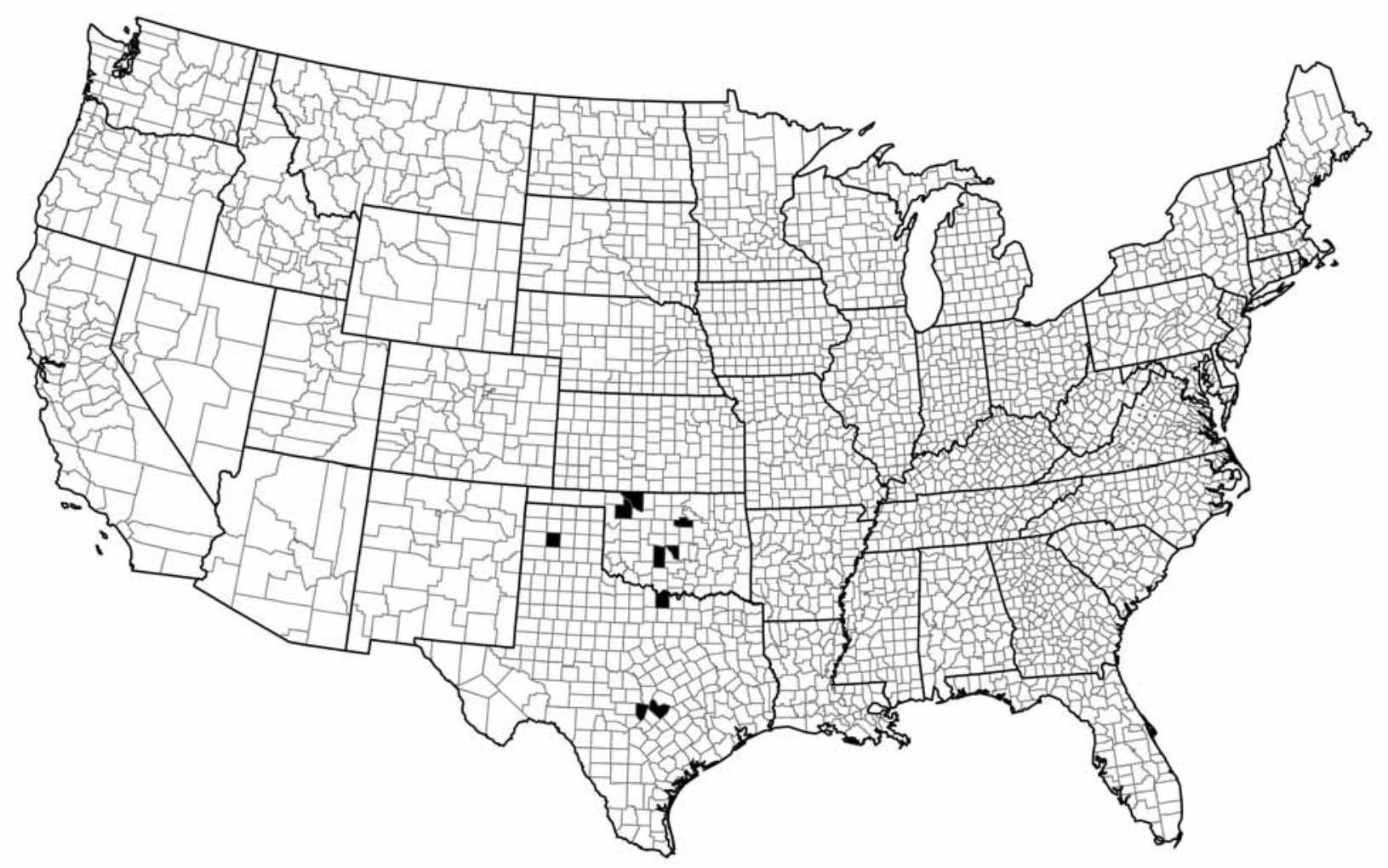

FIGURE 11. Distribution of Ceraturgus oklahomensis by county.

Distribution (FIG. 11). Oklahoma and Texas.

Discussion. In males, the legs are usually dark brown and concolorous with the remainder of the body. In females, the legs are reddish brown to yellowish brown, and usually considerably lighter than the remainder of the body.

Hull (1962) illustrated the head, antenna, wing, and male postabdomen.

Most specimens have been collected from late March to late April.

\section{Ceraturgus (Ceraturgopsis) cornutus (Wiedemann) \\ (FIGS 10B, 10C, 12)}

Dasypogon cornutus Wiedemann, 1828: 382.

Ceraturgopsis cornutus Johnson: 1903: 111. 
Type material examined. Lectotype, female: "North American?", "cornutus, = cruciatus, Alte Sammlung, Type, Wdm", "Type” [red label], "cornutus, det. Hermann", "Ceraturgus cornutus Wied.” [gray label, handwritten], NMW.

Additional material examined. UNITED STATES. ALABAMA. Monroe County: 1 mi. SE of Franklin, 3142’32”N 87²3’21”W, 27 May 1995, T. L. Schiefer, ㅇ, MEM.

ARKANSAS. Benton County, 7 June 1933, ㅇ, S. A. Summerland, UAAM. Washington County: 5 June 1960, 12 June 1939 and 17 June 1941, one with a second label, Oenothera, 3 ㅇ, UAAM (examined by JW, now apparently lost).

FLORIDA. Liberty County: Torreya State Park, 14 May 1964, ㅇ, R. E. White, FSCA; 5 April 1967, ox , H. V. Weems, Jr., FSCA; 9 May 1968, ㅇ, H. V. Weems, Jr., FSCA; 9-17 May 1968, Malaise trap, 우, H. V. Weems, Jr.; 13 May 1968, 3 우 H. V. Weems, Jr. and G. H. Heinrich; 14 May 1968, 우, H. V. Weems, Jr., FSCA; 6-7 May 1969, ㅇ, H. V. Weems, FSCA; 16 May 1970, 우, H. V. Weems, Jr., FSCA; 1 May 1973, 2 ox, 2 ㅇ, H. V. Weems, Jr., FSCA.

GEORGIA. Effingham County: New Ebenezer Center, 5 mi. NE of Rincon, 4 May 1997, C. R. Nelson, 우, BYU; 6 May 1997, C. R. Nelson, ox , BYU.

TENNESSEE. Marion County: Chattanooga, 23 June 1952, W.J. Hanson, + , EMUS.

Female. Body length: 15.3-26.9 mm (mean \pm S.D.: $19.0 \pm 3.2, \mathrm{~N}=14$ ).

Head. Width 1.5 times eye height. Face golden tomentose. Frons, vertex except for ocellar tubercle, postcranium, and gena golden pollinose. Face with sparse mystax of golden setae confined to lower fifth; upper face with sparse, short golden setae reaching to antennal bases. Frons laterally with short golden setae. Ocellar triangle tuberculate, with 8-10 golden setae. Postocular setae golden, stout. Postgena and stipes with dense vestiture of long, slender, apically crinkled, golden hair-like setae. Proboscis brown, laterally compressed, about 4 times as long as deep. Palpal segments about equal in length, golden pollinose, both segments with long golden setae. Antenna 3.9-4.4 mm long; scape golden pollinose, with golden ventrolateral setae; pedicel and flagellomeres dark brown; antennomere:scape ratios 1.0:1.0:3.7:0.5:1.1.

Thorax. Cervical sclerites brown, sparsely golden pollinose, with dense vestiture of long, slender, apically crinkled, golden hair-like setae. Pronotum golden pollinose, with sparse pile of long, slender, golden setae covering antepronotum and posterolateral corners of postpronotum; postpronotal lobe with erect golden setae along anterior edge and short, reclinate, golden hair-like setae on disc. Propleuron with dense vestiture of long, declinate, golden hair-like setae on proepisternum and reclinate hair-like setae on anterior portion of proepimeron. Prosternum golden pollinose, lacking setae. Scutum reddish brown in ground color, golden pollinose except for central brown vitta extending from pronotum nearly to scutellum and pair of broad posterolateral patches, each divided by narrow line of golden pollen along transverse suture, reaching from behind postpronotal lobes almost to scutellum; with sparse, short, reclinate golden hair-like setae on golden pollinose areas and narrow mid-dorsal longitudinal line and with prescutellar patch of longer, reclinate, golden hair-like setae; non-pollinose areas mostly devoid of setae. Lateral margin of scutum with 3 strong, pale presutural setae and 6-8 strong, pale postsutural, supra-alar setae. Postalar callus with 3-4 stout golden setae and many short hair-like setae. Scutellum golden pollinose, with short golden hair-like setae on disc and 6-8 moderately strong, golden setae and several fine hair-like setae along margin; marginal scutellar setae shorter than or equal to length of scutellum. Mediotergite brown. Anatergite and katatergite golden pollinose; katatergite with a fan of long, slender, apically crinkled, golden hair-like setae. Mesopleural sclerites mostly golden pollinose, less so on lower katepisternum and meron. Posterior half of anepisternum covered with long, fine, golden, apically crinkled hair-like setae; dorsal setae declinate, ventral setae reclinate. Anterior basalare brown; posterior basalare light golden pollinose. Katepisternum with few fine, golden, hair-like setae centrally. Anepimeron, katepimeron, and meron lacking setae. Basal swelling of pleural wing process golden pollinose. 
Subalar sclerite brown. Metepisternum and metepimeron golden pollinose; metepimeron with long, fine, apically crinkled, golden hair-like setae.

Legs. Uniformly brown. Coxae golden pollinose; prothoracic and mesothoracic coxae densely covered with long, slender, golden hair-like setae on anterior and lateral surfaces; metathoracic coxa with similar hairlike setae anteroventrally and posterolaterally. All trochanters, femora, tibiae, and tarsi shining golden brown; all claws black with brown base. All femora with circlets of several stout, golden setae near apex; prothoracic and mesothoracic femora with single golden seta anteriorly basad of middle; metathoracic femur with anterior row of 5-6 golden bristles. Prothoracic tibia with anterodorsal and posterodorsal row of short golden setae and anteroventral and posteroventral row of long golden setae; mesothoracic tibia with anterodorsal, anteroventral, and posteroventral rows of long golden setae, posterodorsal row with weaker setae; metathoracic tibia with dorsal, anterior, and anteroventral rows of long golden setae. First tarsomere subequal in length to second and third combined. All pulvilli pale yellow.

Wing (FIG.10C). 11.7-17.3 mm long (mean \pm S.D.: $14.9 \pm 1.8, \mathrm{~N}=13$ ). Almost uniformly medium brown, somewhat lighter posteriorly, with small dark area near anterior margin in vicinity of apex of vein Sc; small area of membrane at base of cell $r_{1}$ and corresponding area across vein $\mathrm{R}_{1}$ in cell sc hyaline; small area of membrane at base of cell d hyaline. Halter with stem golden brown, knob brown.

Abdomen. Tergites 1-5 with broad shining brown anterior margin and broad golden pollinose posterior marginal bands; bands not wider at lateral margins of tergites than at midline; tergites $2-5$ with anterior longitudinal dark bands at midline, with pollinose bands broadest near middle; tergite 1 with long, slender, apically crinkled, golden, anterolateral hair-like setae and about 9-12 stout, posterolateral, golden setae; tergites 6-7 brown, shining. Sternites $2-4$ golden pollinose; sternite 5 shining brown, golden pollinose posteriorly and laterally; sternites 1-3 with long, slender, apically crinkled, golden hair-like setae; sternites 4-5 with shorter hair-like setae than preceding sternites; sternites 6-7 shining brown.

Male. Similar to female except as follows:

Body length: $13.8-19.5 \mathrm{~mm}$ (mean \pm S.D.: $15.7 \pm 2.6, \mathrm{~N}=4$ ).

Head. Mystax dense, consisting of many long, apically crinkled, golden hair-like setae. Antenna $3.9 \mathrm{~mm}$ long; antennomere:scape ratios 1.0:1.0:3.8:0.3:1.0.

Thorax. Hair-like setae of postpronotal lobe and prescutellar area of scutum dense and long. Marginal scutellar setae as long as or longer than length of scutellum.

Legs. Prothoracic and mesothoracic coxae densely covered with long, apically crinkled golden hair-like setae. All femora reddish brown to dark brown, with many long, apically crinkled golden hair-like setae ventrally; prothoracic and metathoracic femora lacking setae anteriorly; metathoracic femur with anterior row of 3-4 golden setae. Prothoracic tibia with thick ventral brush of very long, apically crinkled, golden hair-like setae; mesothoracic tibia with sparse anterodorsal, anteroventral, and posteroventral rows of long golden hairlike setae. All pulvilli pale yellow.

Wing (FIG. 10B). 12.1-13.9 mm long (mean \pm S.D.: $12.7 \pm 0.8, \mathrm{~N}=4$ ). Similar to female wing.

Abdomen. Tergites 1-6 with broad shining brown anterior margin and broad white or pale golden pollinose posterior margin. Sternites 1-7 mostly pale golden pollinose.

Distribution (FIG. 12). Southeastern; Georgia and Florida west to Arkansas.

Discussion. This species is similar to C. johnsoni. Martin (1965) found one female syntype in the Naturhistorisches Museum Wien, which he designated as lectotype. Abdominal tergites 2-5 of the lectotype have broad, yellow pollinose bands posteriorly, and abdominal tergites 6-8 are polished. Sternites 1-4 are mostly yellow pollinose. The remaining sternites have been destroyed by museum pests. Female $C$. johnsoni have posterior pollinose bands on tergites 2-7.

Males of $C$. cornutus have the posterior margins of tergites 1-6 white or pale golden pollinose; sternites 1-7 are mostly pale golden pollinose. However, as in the females, the dark brown, non-pollinose areas of the scutum lack hair-like setae, except for a narrow median longitudinal line and a prescutellar patch of short, rec- 
linate, golden hair-like setae. These bare areas are sufficient to separate $C$. cornutus from the smaller $C$. johnsoni, which has the scutum covered with short, reclinate, golden hair-like setae throughout.

Compared to females, the males have a denser mystax of longer, apically crinkled hair-like setae; a denser ventral brush of longer, apically crinkled hair-like setae on the anterior tibiae, and femora that are much darker than other leg segments.

Back (1909) illustrated the antenna and female dorsal aspect.

Most specimens have been collected in May.

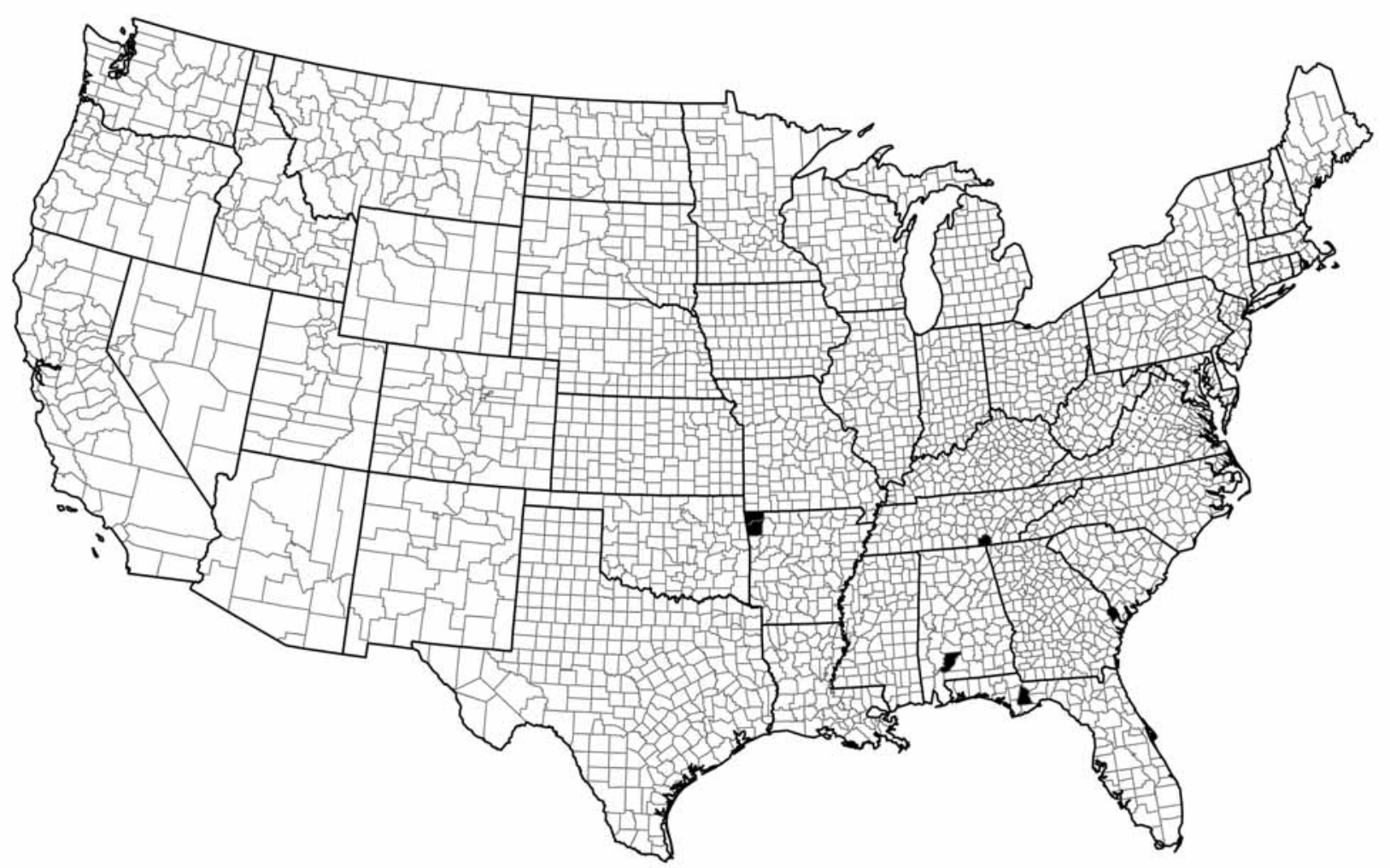

FIGURE 12. Distribution of Ceraturgus cornutus by county.

\section{Ceraturgus (Ceraturgopsis) johnsoni Martin}

(FIGS 10D, 10E, 13)

Ceraturgus johnsoni Martin, 1965: 119.

Type material examined. Holotype, female, UNITED STATES: "Holotype, Ceraturgus johnsoni Chas. H. Martin” (pink label), "FLORIDA”, “C. W. Johnson Collection”, “M. C. Z. Holotype 32752” (red label), "Ceraturgus johnsoni Martin det. C. H. Martin 1963", "Jan.-July 2003 MCZ image database”, MCZ. Paratype, female, UNITED STATES: "FLORIDA", "C. W. Johnson Collection", "Paratype Ceraturgus johnsoni Chas. H. Martin” (yellow label), "M. C. Z. Paratype 32752" (pink label), MCZ. Paratype, male, UNITED STATES: "FLORIDA", "C. W. Johnson Collection", "Ceraturgopsis cornutus (Wd.)" (handwritten label with red outline), USNM. These specimens were incorrectly identified by Johnson as $C$. cornutus. They are the basis for the genus Ceraturgopsis Johnson. According to Johnson (1903), they were collected in Ormond (Volusia County), Florida, in April by Mrs. Annie T. Slosson.

Additional material examined. UNITED STATES. FLORIDA. County unknown: "S. Fla.", March 1923, J. S. Hine, ㅇ, OSU; "Florida”, C. W. Johnson, ơ, USNM; "Fla.", A. T. Slosson, 우, AMNH. Citrus 
County: 20 March 1957, H. V. Weems, Jr., , CSCA. Levy County: Gunntown (Gulf Hammock), March, P. Laurent, 2 ㅇ, ANSP; Gulf Hammock, 23 April 1952, J. R. Vockeroth, ㅇ, CNC. Liberty County: Torreya State Park near Rock Bluff, 21 April 1989, J. M. Cumming, 우, CNC. Volusia County: Ormond, A. T. Slosson, $o^{\star}$, AMNH.

Female. Body length: $13.7-17.6 \mathrm{~mm}$ (mean \pm S.D.: $14.8 \pm 1.4)$.

Head. Width 1.5 times eye height. Face golden tomentose. Frons, vertex except for ocellar tubercle, postcranium, and gena golden pollinose. Face with mystax of golden setae confined to lower fifth; upper face with sparse, short golden setae reaching to antennal bases. Frons laterally with short golden setae. Ocellar triangle tuberculate, with about 14 golden setae. Postocular setae golden, stout. Postgena and stipes with dense vestiture of long, slender, apically crinkled, golden hair-like setae. Proboscis brown, laterally compressed, about 4 times as long as deep. Palpal segments about equal in length, basal segment brown, apical segment golden pollinose, both segments with long golden setae. Antenna 3.2-3.4 mm long; scape golden pollinose, with golden ventrolateral setae; pedicel and flagellomeres dark brown (holotype flagellomeres missing); antennomere:scape ratios (allotype specimen) 1.0:1.0:3.4:0.4:1.1.

Thorax. Cervical sclerites brown, with dense vestiture of long, slender, apically crinkled, golden hair-like setae. Pronotum golden pollinose, with sparse pile of long, slender, golden setae covering antepronotum and posterolateral corners of postpronotum; postpronotal lobe with erect golden setae along anterior edge and short, reclinate, golden hair-like setae on disc. Propleuron with dense vestiture of long, declinate, golden hairlike setae on proepisternum and reclinate hair-like setae on anterior portion of proepimeron. Prosternum golden pollinose centrally, brown laterally, lacking setae. Scutum reddish brown in ground color, golden pollinose except for wide central brown vitta extending from pronotum nearly to scutellum and pair of broad posterolateral patches, each divided by narrow line of golden pollen along transverse suture, reaching from behind postpronotal lobes almost to scutellum; with sparse, short, reclinate golden hair-like setae throughout, including non-pollinose areas, and prescutellar patch of longer, reclinate, golden hair-like setae. Lateral margin of scutum with 3-5 strong, pale presutural setae and 5-7 strong, pale postsutural, supra-alar setae. Postalar callus with 3-4 stout golden setae and many short hair-like setae. Scutellum golden pollinose, with short, golden hair-like setae on disc and 6 moderately strong golden setae and several fine hair-like setae along margin; marginal scutellar setae shorter than or equal to length of scutellum. Mediotergite brown. Anatergite and katatergite golden pollinose; katatergite with a fan of long, slender, apically crinkled, golden hair-like setae. Mesopleural sclerites mostly golden pollinose, less so on lower katepisternum and meron. Posterior half of anepisternum covered with long, fine, golden, apically crinkled hair-like setae; dorsal setae declinate, ventral setae reclinate. Anterior basalare brown; posterior basalare silvery pollinose. Katepisternum with a few fine, golden hair-like setae centrally. Anepimeron, katepimeron, and meron lacking setae. Basal swelling of pleural wing process golden pollinose. Subalar sclerite brown. Metepisternum and metepimeron golden pollinose; metepimeron with long, fine, apically crinkled, golden hair-like setae.

Legs. Uniformly golden brown. Coxae golden pollinose on anterior and lateral surfaces, brown on posterior surface; prothoracic and mesothoracic coxae densely covered with long, slender, golden, apically crinkled hair-like setae on anterior and lateral surfaces; metathoracic coxa with similar hair-like setae anteroventrally and posterolaterally. All trochanters, femora, tibiae, and tarsi shining golden brown; all claws black with brown base. All femora with circlets of several stout, golden setae near apex and $2-4$ golden setae on anterior surface near middle. Prothoracic tibia with anterodorsal and posterodorsal row of short golden setae and posteroventral row of long golden setae; mesothoracic tibia with anterodorsal, anteroventral, and posteroventral rows of long golden setae, posterodorsal row with weaker setae; metathoracic tibia with dorsal, anterior and anteroventral rows of long golden setae. First tarsomere subequal in length to second and third combined. All pulvilli pale yellow.

Wing (FIG.10E). 10.7-14.2 mm long (mean \pm S.D.: $12.5 \pm 1.1$ ). Almost uniformly medium brown, somewhat lighter posteriorly, with small dark area near anterior margin in vicinity of apex of vein Sc; small area of 
membrane at base of cell $r_{1}$ and corresponding area across vein $R_{1}$ in cell sc hyaline; small area of membrane at base of cell $\mathrm{d}$ hyaline. Halter with stem golden brown, knob brown.

Abdomen. Tergites 1-7 with broad shining brown anterior margin and broad golden pollinose posterior marginal bands; pollinose bands of tergites $2-5$ broadest in middle, not significantly widened at lateral margins; tergite 1 with long, slender, apically crinkled, golden anterolateral hair-like setae and about 9-12 posterolateral golden setae. Sternites 1-4 golden pollinose, with long, slender, apically crinkled, golden hair-like setae; sternites 5-7 golden pollinose, but with anterior shining brown areas and shorter hair-like setae than preceding sternites.

Male. Similar to female except as follows:

Body length: $14.4-16.0 \mathrm{~mm}$.

Head. Mystax dense, consisting of many long, apically crinkled, golden hair-like setae. Antenna $3.3 \mathrm{~mm}$ long; antennomere:scape ratios 1.0:1.0:3.7:0.4:1.0.

Thorax. Hair-like setae of postpronotal lobe and prescutellar area of scutum dense and long. Marginal scutellar setae as long as or longer than length of scutellum.

Legs. Prothoracic and mesothoracic coxae densely covered with long, apically crinkled golden, hair-like setae. All femora with many long, apically crinkled, golden hair-like setae ventrally; metathoracic femora with anterior row of 2-3 golden setae; metathoracic femur with anterior row of 4-5 golden setae. Prothoracic tibia with thick ventral brush of very long, apically crinkled, golden hair-like setae, mesothoracic tibia with sparse anterodorsal, anteroventral, and posteroventral rows of long golden hair-like setae. All pulvilli pale yellow.

Wing (FIG. 10D). 11.7-12.9 mm long (mean: 12.3). Similar to female wing.

Abdomen. Tergites 1-6 with broad shining brown anterior margin and broad golden pollinose posterior margin. Sternites 1-6 golden pollinose, 3-6 shining brown anteromedially.

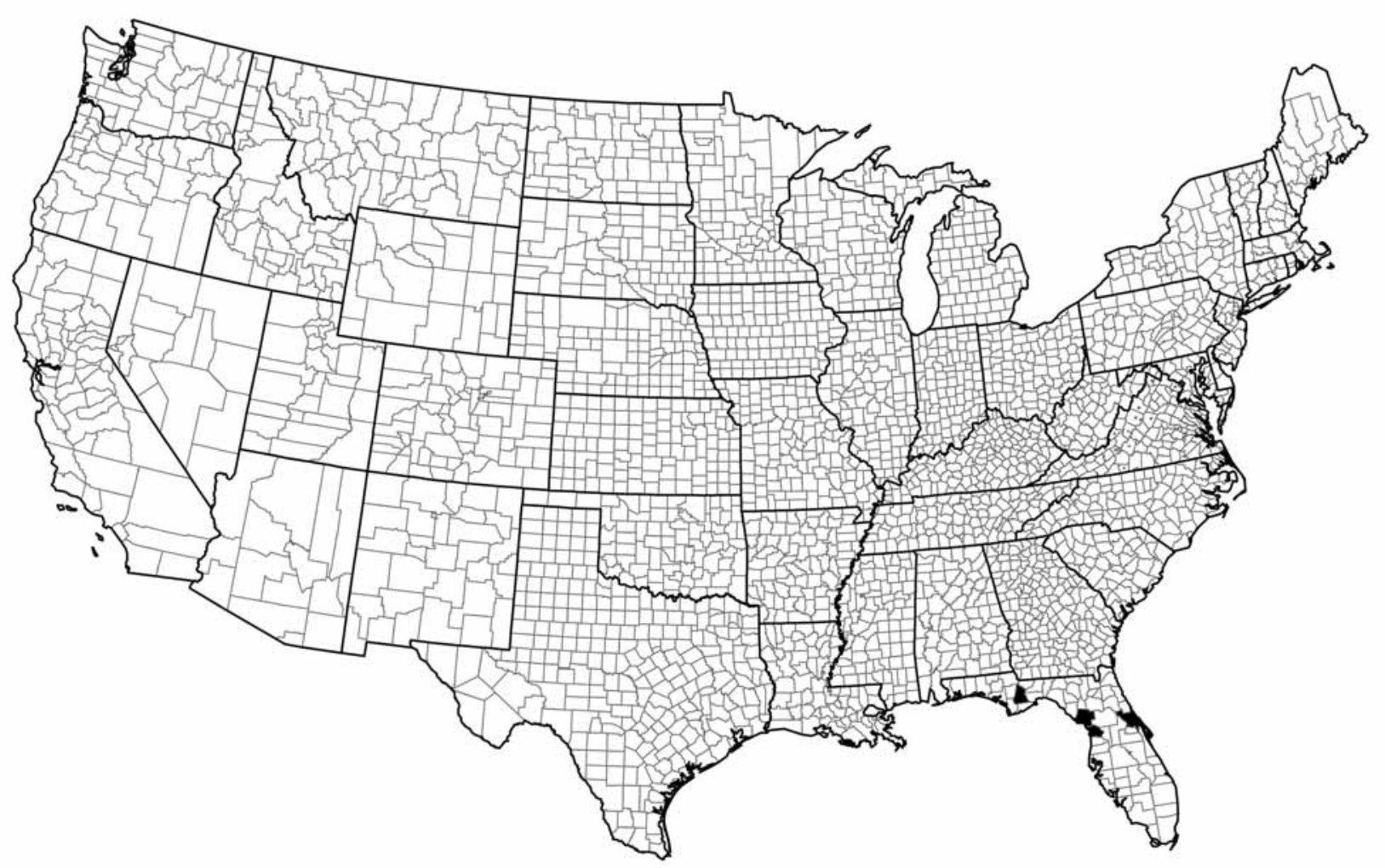

FIGURE 13. Distribution of Ceraturgus johnsoni by county. 
Distribution (FIG. 13). Florida.

Discussion. Martin (1965) figured the antenna of $C$. johnsoni and the wing and abdominal tergites of $C$. johnsoni and C. cornutus.

Specimens have been collected in March and April.

\section{Species incertae sedis}

\section{Ceraturgus niger Macquart}

Ceraturgus niger Macquart, 1838: 25.

Macquart (1838) described Ceraturgus niger "de l'Amérique boréale." Walker (1854) later listed it from Mexico. Osten Sacken (1878) transferred it to Taracticus without explanation. Brauer (1883) did not find the stout, enlarged spine at the apex of the fore tibia that is found in Taracticus. He and Williston (1884) felt that C. niger did not belong in Taracticus. Macquart's (1838) illustrations show five antennomeres, with the third flagellomere longer than the scape, and much shorter than the first flagellomere. He described it as a small (about $8.5 \mathrm{~mm}$ long), black species with grayish yellow face and front, yellowish mystax, yellowish wings, having white spots on some of the abdominal segments. Macquart's $C$. niger cannot be a species of Taracticus, but no known North American species of Ceraturgus fits its description.

\section{Acknowledgments}

I am grateful to Eric M. Fisher (CDFA) for providing me with a copy of the unfinished Wilcox manuscript on North American Ceraturgus, and to Fritz Geller-Grimm (MWNH) for assistance in obtaining and translating literature.

The following individuals allowed me to study type specimens in their care and answered questions regarding type specimens: Thomas Pape (ZMUC), Philip D. Perkins (MCZ); Peter Sehnal (NMW); David Notton (BMNH), Zachary H. Falin (SEMC), F. Christian Thompson (USNM), and Robert Blinn (NCSU).

The following individuals lent specimens from their respective collections: David A. Grimaldi (AMNH); Jason D. Weintraub (ANSP); Frank Merickel (BEMI); David Notton (BMNH); Shawn M. Clark (BYU); Norman D. Penny (CAS); Joe B. Keiper (CLEV); Chen W. Young (CMNH); Jeffrey M. Cumming (CNC); Eric Fisher (CSCA); Boris C. Kondratieff (CSUC); John Morse, (CUAC); E. Richard Hoebeke (CUIC); Charles R. Bartlett (UDCC); Cheryl Barr (EMEC); James H. Boone (FMNH); Gary Steck (FSCA); Cecil L. Smith (UGCA); Colin Favret (INHS); Richard S. Zack (WSU); Gregory Zolnerowich (KSUC); Victoria Moseley Bayless (LSAM); Philip D. Perkins (MCZ); Terence Lee Schiefer (MEM); Robert Blinn (NCSU); F. Christian Thompson (USNM); Tim L. McCabe (NYSM); Don C. Arnold (OSEC); Luciana Musetti and Creighton Freeman (OSU); Timothy Tomon (PSUC); Zachary H. Falin (SEMC); Edward G. Riley (TAMU); Robert W. Sites (UMRM); Philip J. Clausen (UMSP); Mark F. O'Brien (UMMZ); Colin Brammer (EMUS); Scott R. Shaw (ESUW); Steven Krauth (IRCW); W. David Sissom (WTAM).

\section{References}

Anonymous (1919) Proceedings of the New York Entomological Society. Meeting of October 7. Journal of the New York Entomological Society, 27, 345-347.

Artigas, J.N. \& Papavero, N. (1988) The American genera of Asilidae (Diptera): keys for identification with an atlas of 
female spermathecae and other morphological details. I. Key to subfamilies and subfamily Leptogastrinae Schiner. Gayana Zoología, 52(1-2), 95-114.

Artigas, J.N. \& Papavero, N. (1991a) The American genera of Asilidae (Diptera): keys for identification with an atlas of female spermathecae and other morphological details. VII.1. Subfamily Stenopogoninae Hull. A preliminary classification into tribes. Gayana Zoología, 55(2), 139-144.

Artigas, J.N. \& Papavero, N. (1991b) The American genera of Asilidae (Diptera): keys for identification with an atlas of female spermathecae and other morphological details. VII.2. Subfamily Stenopogoninae Hull - Tribes Acronychini, Bathypogonini (with description of a new genus) and Ceraturgini, and a catalogue of the neotropical species. Gayana Zoología, 55(3), 247-255.

Back, E.A. (1909) The robber-flies of America north of Mexico, belonging to the subfamilies Leptogastrinae and Dasypogoninae. Transactions of the American Entomological Society, 35, 137-400.

Barnes, M.M. (1984) Joseph Wilcox, 1901-1982. Bulletin of the Entomological Society of America, 30(2), 58-61.

Brauer, F. (1883) Ueber die Gattung Isopogon Loew. Wiener Entomologische Zeitung, 2, 53-56.

Brimley, C.S. (1924) Three supposed new species of Ceraturgus (Diptera, Asilidae) from North Carolina. Entomological News, 35, 8-12.

Bromley, S.W. (1928) Some North American Asilidae; their models and their prey recorded. Proceedings of the Royal Entomological Society of London, 2(3), 54-55.

Bromley, S.W. (1934) Two new dasypogonine robber flies from the Southwest (Asilidae: Diptera). Journal of the New York Entomological Society, 42, 225-226.

Bromley, S.W. (1946) Guide to insects of Connecticut. Part VI. The Diptera or True Flies of Connecticut. Third fascicle, Asilidae. Connecticut State Geological and Natural History Survey Bulletin, 69, 51 pp.

Bromley, S.W. (1950a) Florida Asilidae (Diptera) with description of one new species. Annals of the Entomological Society of America 43: 227-239.

Bromley, S.W. (1950b) Ohio robber flies V. (Diptera: Asilidae). Ohio Journal of Science, 50, 229-234.

Byers, G.W., Blank, F., Hanson, W. J., Beneway, D. F. and Fredrickson, R. W. (1962) Catalogue of the types in the Snow Entomological Museum. Part III (Diptera). University of Kansas Science Bulletin, 43(5), 131-181.

Engel, E.O. (1934 (1933)) Schwedisch-chinesische wissenschaftliche Expeditionen nach den nordwestlichen Provinzen Chinas, unter Leitung von Dr. Sven Hedin und Prof. Sü Ping-chang. Insekten gesammelt vom schwedischen Arzt der Expedition Dr. David Hummel 1927-1930. II. Diptera. 3. Asilidae. Arkiv för Zoologi, 25A(22), 17 pp.

Evenhuis, N.L. (2008) Insect and spider collections of the worldwebsite. Available from http//hbs.bishopmuseum.org/ codens/codens-inst.html (accessed 4/9/2008).

Fabricius, J.C. (1805) Systema antiatorum secundum ordines, genera, species adiectis synonymis, locis, observationibus, descriptionibus. Brunsvigae, $373 \mathrm{pp}$.

Fattig, P.W. (1945) The Asilidae or robber flies of Georgia. Emory University Museum Bulletin, 3, 1-33.

Geller-Grimm, F. (2003) A world catalogue of the general of the family Asilidae (Diptera). Studia dipterologica, 10(2), 473-526.

Harusawa, K. (1997) [Ecology of Ceraturgus kawamurae Matsumura and Cyrtopogon pictipennis Coquillett (Diptera, Asilidae)]. Hana Abu 3, 57-58 [in Japanese, translation available from http://www.geller-grimm.de/catalog/ transla.htm (accessed 17 March 2006)].

Hull, F.M. (1962) Robberflies of the World. The genera of the family Asilidae. United States National Museum Bulletin, 224(1-2), $907 \mathrm{pp}$.

International Commission on Zoological Nomenclature (1999) International Code of Zoological Nomenclature, fourth edition. International Trust for Zoological Nomenclature, London, $306 \mathrm{pp}$.

James, M.T. (1939) A preliminary review of certain families of Diptera from the Florissant Miocene beds. II. Journal of Paleontology, 13(1), 42-48.

Johnson, C.W. (1903) A new genus and four new species of Asilidae. Psyche, 10, 111- 114.

Johnson, C.W. (1910) Some additions to the dipteran fauna of New England. Psyche, 17(6), 228-235.

Johnson, C.W. (1912) New and interesting Diptera. Psyche, 19, 151-153.

Johnson, C.W. (1913) Insects of Florida. I. Diptera. Bulletin of the American Museum of Natural History, 32, 37-90.

Kertész, C. (1909) Catalogus dipterorum hucusque descriptorum. Volumen IV. Oncodidae, Nemestrinidae, Mydaidae, Apioceridae, Asilidae. Museum Nationale Hungaricum, Budapestini. 349 pp.

Loew, H. (1873) Beschreibungen europäisher Dipteren. Dritter Band. Pp. 120-145 in Systematische Beschreibung der bekannten europäischen zweiflügeligen Insecten, von Johann Wilhelm Meigen. Zehnter Theil oder vierter Supplementband. Bearbeitet von Hermann Loew. Halle, 320 pp.

Macquart, J. (1834) Histoire naturelle des Insectes. Diptères, Tome premier. Paris, 578 pp.

Macquart, J. (1838) Diptères exotiques nouveaux ои реи connus. Vol. 1, Pt. 2. Paris, pp. 5-207.

Malloch, J.R. (1917) A preliminary classification of Diptera, exclusive of Pupipara, based upon larval and pupal characters, with keys to imagines in certain families. Part I. Bulletin of the Illinois State Laboratory of Natural History, 12 , $161-409$. 
Martin, C.H. (1965) Generic and subfamily changes, new synonymy, new names, a newspecies, and notes on Asilidae (Diptera). Journal of the Kansas Entomological Society, 38(2), 110-134.

Martin, C.H. \& Papavero, N. (1970) Family Asilidae. A catalogue of the Diptera of the Americas south of the United States [Museu de Zoologia, Universidade de São Paulo] 35b, 139 pp.

Matsumura, S. (1916) Thousand insects of Japan. Additamenta II, pp. 185-474 [in Japanese].

McAlpine, J.F. (1981) Morphology and Terminology — Adults. In: McAlpine, J.F., Peterson, B.V., Shewell, G.E., Vockeroth, J.R. \& Wood, D.M. (Coords.), Manual of Nearctic Diptera, Volume 1, Research Branch, Agriculture Canada, Monographs, 27, 2-63.

Ohishi, H. (1997) [Asilidae congregating around flowers]. Hana Abu 3, 52 [in Japanese, translation available at http:// www.geller-grimm.de/catalog/transla.htm (accessed 17 March 2006)].

Osten Sacken, C.R. (1878) Catalogue of the described Diptera of North America, second edition. Smithsonian Miscellaneous Collections 270, 276 pp.

Papavero, N. (1973) Studies of Asilidae (Diptera) systematics and evolution. I. A preliminary classification in subfamilies. Arquivos de Zoologia, 23(3), 217-274.

Petch, C.E. (1934) Errata and additions to the insects of the Province of Quebec; Part II, Diptera. Annual Report of the Quebec Society for the Protection of Plants, 25-26 (1932-1934), 88-90.

Say, T. (1823) Descriptions of dipterous insects of the United States. Journal of the Academy of Natural Sciences of Philadelphia, 3(1), 9-54, 73-104.

Stone, A. (1980) History of Nearctic Dipterology. Volume 1 (Handbook), Part 1 in G. C. D. Griffiths (ed.), Flies of the Nearctic Region. 62 pp.

Walker, F. (1849) List of the specimens of dipterous insects in the collection of the British Museum. Part II. Trustees of the British Museum, London, pp. 231-484.

Walker, F. (1854) List of the specimens of dipterous insects in the collection of the British Museum. Part VI. Supplement II. Trustees of the British Museum, London, pp. 331-506.

Wiedemann, C.R.W. (1824) Munus rectoris in Academia Christiana Albertina aditurus analecta entomologica ex Museo Regio Havniensi. Kiliae, 60 pp.

Wiedemann, C.R.W. (1828) Aussereuropäische zweiflügelige Insekten, volume 1. Hamm. 608 pp.

Weiss, H.B. \& Ziegler, G.M. (1931) Thomas Say: Early American Naturalist. Charles C. Thomas, Springfield, Illinois, $260 \mathrm{pp}$.

Williston, S.W. (1884) On the North American Asilidae (Dasypogoninae, Laphrinae), with a new genus of Syrphidae. Transactions of the American Entomological Society, 11, 1-35.

Williston, S.W. (1886) Dipterological notes and descriptions. Transactions of the American Entomological Society, 13, 287-307.

Wood, G.C. (1981) Asilidae. In: McAlpine, J.F., Peterson, B.V., Shewell, G.E., Vockeroth, J.R. \& Wood, D.M. (Coords.), Manual of Nearctic Diptera, Volume 1, Research Branch, Agriculture Canada, Monographs, 27, 549-573. 